\title{
Some Tertiary Brachiopods of the \\ East Coast of the United States
}

G. ARTHUR COOPER

SMITHSONIAN CONTRIBUTIONS TO PALEOBIOLOGY • NUMBER 64 


\title{
SERIES PUBLICATIONS OF THE SMITHSONIAN INSTITUTION
}

Emphasis upon publication as a means of "diffusing knowledge" was expressed by the first Secretary of the Smithsonian. In his formal plan for the Institution, Joseph Henry outlined a program that included the following statement: "It is proposed to publish a series of reports, giving an account of the new discoveries in science, and of the changes made from year to year in all branches of knowledge." This theme of basic research has been adhered to through the years by thousands of titles issued in series publications under the Smithsonian imprint, commencing with Smithsonian Contributions to Knowledge in 1848 and continuing with the following active series:

\author{
Smithsonian Contributions to Anthropology \\ Smithsonian Contributions to Astrophysics \\ Smithsonian Contributions to Botany \\ Smithsonian Contributions to the Earth Sciences \\ Smithsonian Contributions to the Marine Sciences \\ Smithsonian Contributions to Paleobiology \\ Smithsonian Contributions to Zoology \\ Smithsonian Folklife Studies \\ Smithsonian Studies in Air and Space \\ Smithsonian Studies in History and Technology
}

In these series, the Institution publishes small papers and full-scale monographs that report the research and collections of its various museums and bureaux or of professional colleagues in the world of science and scholarship. The publications are distributed by malling lists to libraries, universities, and similar institutions throughout the world

Papers or monographs submitted for series publication are received by the Smithsonian Institution Press, subject to its own review for format and style, only through departments of the various Smithsonian museums or bureaux, where the manuscripts are given substantive review. Press requirements for manuscript and art preparation are outlined on the inside back cover.

Robert McC. Adams

Secretary

Smithsonian Institution 
SMITHSONIAN CONTRIBUtions TO PALEOBIOLOGY • NUMBER 64

\section{Some Tertiary Brachiopods of the East Coast of the United States}

G. Arthur Cooper

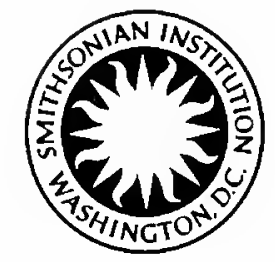

SMITHSONIAN INSTITUTION PRESS

Washington, D.C. 1988 


\begin{abstract}
A B S T R A C T
Cooper, G. Arthur. Some Tertiary Brachiopods of the East Coast of the United States. Smithsonian Contributions to Paleobiology, number 64, 45 pages, 11 figures, 9 plates, 2 tables, 1988. - The Tertiary brachiopod fauna of the United States is discussed and reference is made to the composition of the World Tertiary fauna. The brachiopod fauna of the East Coast of the United States at present numbers 17 genera (4 inarticulates and 13 articulates), of which 11 are discussed herein (asterisk): 2 linguilidids: Glottidia, ${ }^{*}$ Discradisca; 2 craniidinids: Isocrania?* and Crania?*; 2 rhynchonellids: Probolarina* and Cryptopora, the former extinct; 2 cancellothyrids: Eucalathis* and Terebratulina*; 5 extinct terebratulids: Embolosia, Oleneothyris, Plicatoria, ${ }^{*}$ Rhytisoria,* and Tanyoscapha; 2 terebratellids: Argyrotheca* and Platidia; and 2 thecideids: Lacazella* and Thecidellina.* Pliocene Glottidia inexpectans Olsson in adult form is described. New species of Probolarina, Terebratulina, Argyrotheca, Lacazella, and Thecidellina are described and illustrated. Specimens not identified as to species are described: Crania?, Isocrania?, Eucalathis?, and Terebratulina. The remarkable variation of Plicatoria wilmingtonensis (Lyell and Sowerby) is described and illustrated.
\end{abstract}

OfFICIAL PUBLICATION DATE is handstamped in a limited number of initial copies and is recorded in the Institution's annual report, Smithsonian Year. SERIES COVER DESIGN: The trilobite Phacops rana Green.

Library of Congress Cataloging-in-Publication Data

Cooper, G. Arthur (Gustav Arthur), 1902-

Some Tertiary brachiopods of the East Coast of the United States

(Smithsonian contributions to paleobiology ; no. 64)

Bibliography: p.

Supt of Docs.: SI 1.30:64

1. Brachiopoda, Fossil. 2. Paleontology-Teriary. 3. Palcontology-United States. I. Title. II. Series. $\begin{array}{llll}\text { QE701.S56 no. } 64 & 564^{\prime} .8^{\prime} 0974 & 87-600205 & \text { [QE796] }\end{array}$ 


\section{Contents}

Introduction .............................. 1

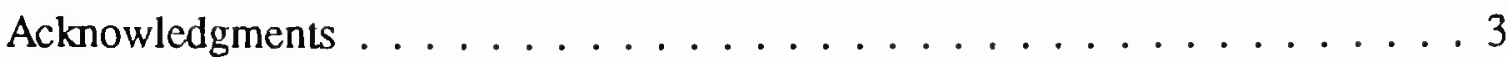

Systematic Hierarchy of Species Described ................ 3

Class Inarticulata Huxley, $1869 \ldots \ldots . \ldots . \ldots$

Genus Glottidia Dall, $1870 \ldots \ldots . \ldots \ldots$

Glottidia inexpectans Olsson, 1914 ................ 4

Genus Crania Retzius, $1781 \ldots \ldots . \ldots . \ldots$

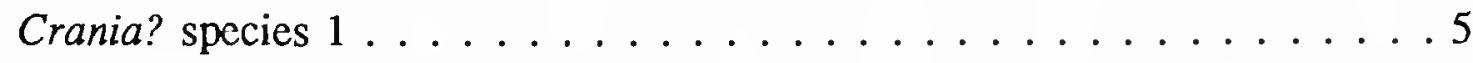

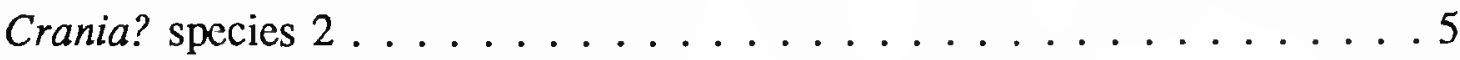

Genus Isocrania Jaekel, $1902 \ldots \ldots \ldots \ldots$

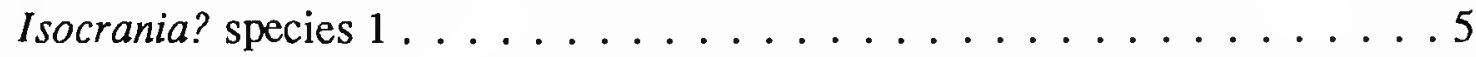

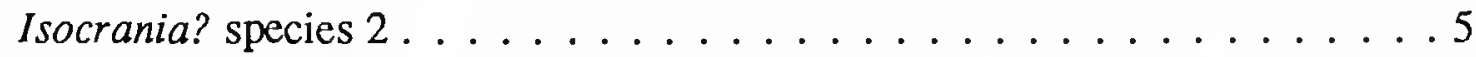

Isocrania? species $3 \ldots \ldots \ldots \ldots$

Class Articulata Huxley, $1869 \ldots \ldots$. . . . . . . . . . . . . 6

Superfamily RHYNCHONELlacEA Gray, $1848 \ldots \ldots$. . . . . . . . . . 6

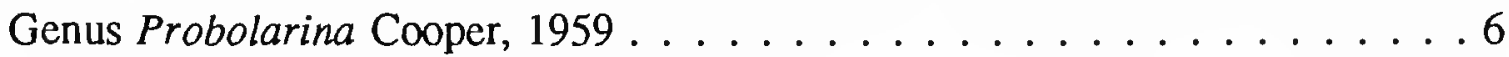

Probolarina brevirostris, new species .............. 6

Probolarina holmesi santeensis, new subspecies . . . . . . . . . 6

Probolarina transversa, new species ................ 7

Superfamily CANCELlOTHYRIDACEA Thomson, 1926 ........... 7

Genus Terebratulina d'Orbigny, $1847 \ldots \ldots \ldots$

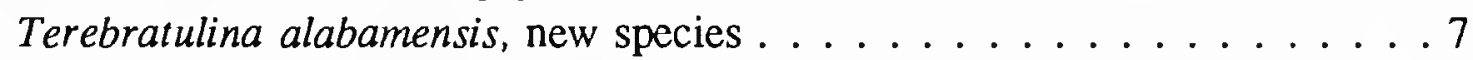

Terebratulina brundidgensis Aldrich, 1907 ............ 8

Terebratulina capillata, new species .............. 8

Terebratulina lachryma (Morton, 1833) ............... 9

Terebratulina wilsoni, new species ................ 10

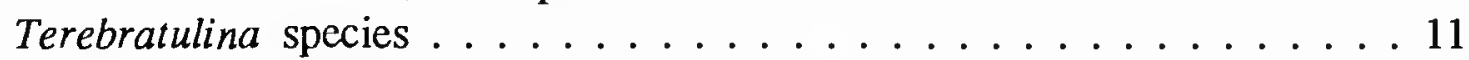

Genus Eucalathis Fischer and Oehlert, 1890 . . . . . . . . . . 11

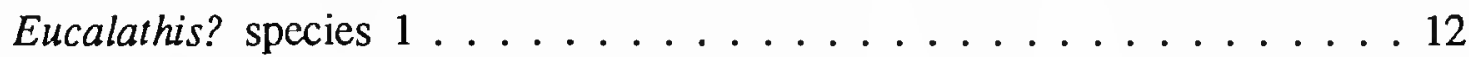

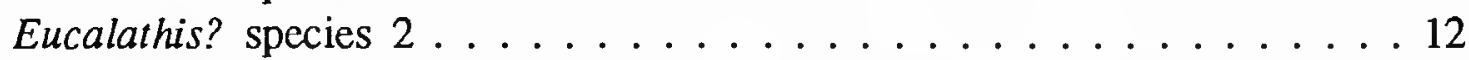

Superfamily Terebratulacea Gray, $1840 \ldots \ldots$. . . . . . . . . . 12

Genus Plicatoria Cooper, 1983 .................. 12

Plicatoria wilmingtonensis (Lyell and Sowerby, 1845) . . . . . . . . 12

Plicatoria parva, new species ................. 18

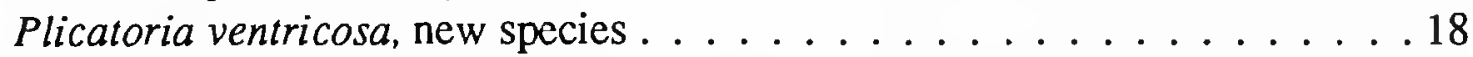

Genus Rhytisoria Cooper, 1983 . . . . . . . . . . . . 19

Rhytisoria alabamensis Cooper, 1983.............. 19

Superfamily TerebratellacEA King, $1850 \ldots \ldots$. . . . . . . . . . . . . . . . . . . . 19

Genus Argyrotheca Dall, 1900 . . . . . . . . . . . . . . . . . . 19

Argyrotheca beecheri (Clark, 1895) . . . . . . . . . . . . 19

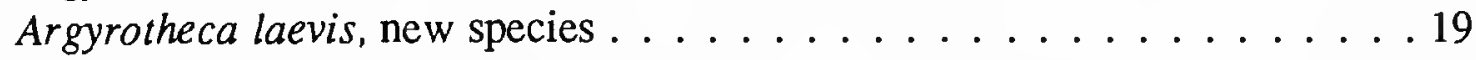

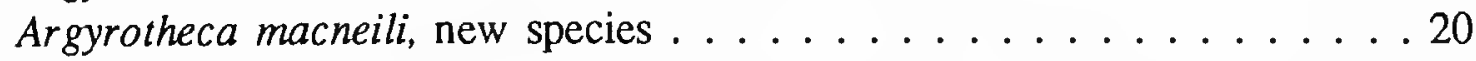

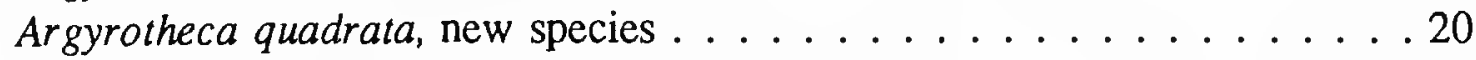

Argyrotheca quadrata transversa, new subspecies ........... 21

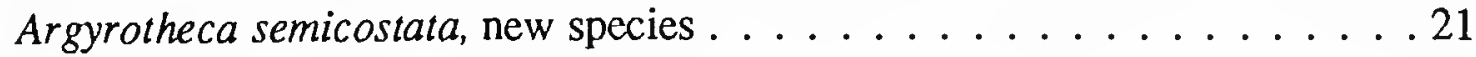


Superfamily THECDEACEA Gray, $1840 \ldots \ldots$. . . . . . . . . . . . . 22

Genus Lacazella Munier-Chalmas, 1881 . . . . . . . . . . . . . . . . . . 22

Lacazella nana, new species . . . . . . . . . . . . . . . . . . . . . . . . . . . . .

Genus Thecidellina Thomson, $1915 \ldots \ldots \ldots \ldots \ldots . \ldots \ldots$

Thecidellina alabamensis, new species . . . . . . . . . . . . 22

Localities . . . . . . . . . . . . . . . . . . . . . . 23

Literature Cited . . . . . . . . . . . . . . . . . . . . . . . . . . .

Plates . . . . . . . . . . . . . . . . . . . . . . 27 


\title{
Some Tertiary Brachiopods of the East Coast of the United States
}

\author{
G. Arthur Cooper
}

\section{Introduction}

Tertiary deposits of the United States are endowed with a variety and abundance of brachiopods only rarely and locally. Few brachiopods were noted and described by early workers in the United States. Schuchert (1897:68) lists only six species of Tertiary brachiopods from the eastern United States: one rhynchonellid that Lyell and Sowerby mistakenly identified as Terebratula wilmingtonensis, 3 "Terebratula," one Terebratulina, and one inarticulate. In the many years since Schuchert's summary, only a few species have been described, mostly from Paleocene and Eocene strata. The present work is designed to make known some new and old species from these Tertiary deposits of the East Coast (including Alabama). Statistical information was obtained from the literature to February 1986; therefore, numbers of genera recorded for the Tertiary and other geological times are suggestive rather than definitive.

Thirty genera of brachiopods have been described from Tertiary sediments of the East, Gulf, and West coasts of the United States. Of these, 18 are now living in the waters of the Atlantic, Gulf of Mexico, and Pacific. Three living genera are known from the Paleocene, 8 from the Eocene, 7 from the Oligocene, 8 from the Miocene, 10 from the Pliocene, and 5 from the Pleistocene. Terebratulina, Argyrotheca, Discinisca, and Discradisca $\propto$ ccur in all of the Tertiary epochs and extend into the Recent. Terebratalia and Dallinella extend from Oligocene to Recent on the West Coast. Only four genera of the East and Gulf Coast Tertiary are known on the West Coast: Glottidia, Discradisca, Terebratulina, and Platidia. Four West Coast genera are extinct: Eogryphus, Miogryphus, Kingena? and Terebratula?. Of East Coast genera, 7 are extinct: Isocrania?, Probolarina, Embolosia, Plicatoria, Oleneothyris,

G. Arthur Cooper, Department of Paleobiology, National Museum of Natural History, Smithsonian Institution, Washington, D.C. 20560.
Tanyoscapha, and Rhytisoria. Identification of Gryphus in the Eocene and the Oligocene of the West Coast is doubtful and no typical Gryphus occurs in the Pacific today, although the genus has been doubtfully identified there. Although Gryphus is known in the Eocene of the Caribbean region (Cooper, 1979), where it is a likely invader from the Mediterranean, it has not been found in the Eocene or later sediments of the Atlantic Coast.

Of the 17 genera of the East Coast Tertiary, 4 are inarticulates: Isocrania?, Crania?, Glottidia, and Discradisca; 2 are rhynchonellids: Cryptopora and Probolarina; 5 are terebratulids: Embolosia, Plicatoria, Tanyoscapha, Oleneothyris and Rhytisoria; 2 belong to the cancellothyrids: Eucalathis? and Terebratulina; 2 to the terebratellids: Argyrotheca and Platidia; and 2 to the thecideids: Lacazella and Thecidellina. The great development of the Terebratulacea and Terebratellacea in the Tertiary took place outside of the United States, chiefly in Australia, New Zealand, Japan, and the Mediterranean borders. The Tertiary rhynchonellids are moderately represented generically in the Southern Hemisphere and the Mediterranean. Hemithiris appears in the Pleistocene of New England and Quebec. It is not known from East Coast Tertiary sediments. It has been recorded from the Tertiary of the West Coast, but the generic identity of some of the species is suspect (H. dibbleei Hertlein and Grant, and H. regani Hertlein and Grant). Cooper (1959:54) placed Hemithiris astoriana Dall in Frieleia.

Terebratula [now Plicatoria] wilmingtonensis Lyell and Sowerby, from the Eocene of North Carolina, is of special interest because of the variation shown in its development of costae. It and some of its aberrations, were illustrated by Dall (1903). A species (now Rhytisoria alabamensis Cooper, 1983) from the Paleocene of Alabama was mistakenly referred to $T$. wilmingtonensis and led to erroneous dating of the formation in which it occurred (Aldrich, 1907:9). Based on exteriors 
TABLE 1.-Numbers of brachiopod genera in existing superfamilies from Triassic to Recent (from files of the National Museum of Natural History, Smithsonian Institution, February 1986).

\begin{tabular}{|c|c|c|c|c|c|c|}
\hline $\begin{array}{l}\text { Class and/or } \\
\text { Superfamily }\end{array}$ & Triassic & Jurassic & Cretaceous & Tertiary & Recent & $\begin{array}{c}\text { Extinct in } \\
\text { Tertiary }\end{array}$ \\
\hline $\begin{array}{l}\text { Inarticulata } \\
\text { Articulata }\end{array}$ & 3 & 4 & 7 & $8^{*}$ & 10 & 2 \\
\hline Rhynchonellacea & 61 & 113 & 30 & 18 & 17 & 8 \\
\hline Cancellothyridacea & 0 & 4 & 13 & 6 & 10 & 2 \\
\hline Terebratulacea & 11 & 136 & 67 & 27 & 19 & 18 \\
\hline Terebratellacea & 13 & 10 & 40 & 62 & 54 & 28 \\
\hline Thecideacea & 2 & 9 & 11 & 4 & 2 & 2 \\
\hline Total & 90 & 276 & 168 & 125 & 112 & 60 \\
\hline
\end{tabular}

Cooper (1983) split the variable T. wilmingtonensis into three genera, Embolosia, Plicatoria, and Tanyoscapha, all with similar loops.

Most marine Tertiary deposits are marginal to the continents and islands. Brachiopods found as fossils in these marginal deposits are often genera and species living offshore today. Along the Atlantic and Gulf coasts fossil and living genera are: Glottidia, Discradisca, Crania, Hemithiris, Terebratulina, Thecidellina, Lacazella, Platidia, Argyrotheca, and Cryptopora. Off the Pacific Coast of the United States, fossil and living genera are: Glottidia, Discinisca, Discradisca, Hemithiris, Terebratulina, Platidia, Terebratalia, Dallinella and Laqueus. Eohemithiris, recorded by Hertlein and Grant (1944) lives today in the southern Pacific. Brachiopods living today off Japan, Australia, New Zealand, South Africa and the Mediterranean shores occur in the marginal Tertiary and Pleistocene deposits. In addition (Cooper, 1982:4) recorded Cryptopora from off the Oregon coast.

The brachiopod fauna of the West Coast of the United States, like that of the American Cretaceous brachiopod fauna, is a limited one. Hertlein and Grant (1944:7) list 14 (15, with Dallinella separated from Terebratalia) genera from the West Coast Tertiary, a fauna slightly less diverse than that of the East Coast. The end of the Cretaceous witnessed a decline in the brachiopods, as well as in other marine phyla. Only 9 genera (10 with doubtful Isocrania) definitely crossed the Cretaceous-Tertiary boundary: Lingula, Discinisca, Discradisca, Crania, Terebratulina, Argyrotheca, Megathiris, Bifolium, and Glazewskia. All but the last two, and Isocrania, are living today. The Cretaceous brachiopod fauna (both extinct and extant) contains 173 genera; that of the Tertiary-Recent numbers 180 (Table 1).

The Jurassic brachiopod fauna of 314 genera declined to 173 in the Cretaceous. The rhynchonellids dropped from 113 genera in the Jurassic, their heyday, to 30 genera in the Cretaceous. The Terebratulacea declined from 136 genera in the Jurassic to 67 in the Cretaceous. The Cancellothyridacea appeared in the Jurassic and increased to 13 genera in the Cretaceous. The zeilleriids declined from 36 genera in the
Jurassic to 5 in the Cretaceous and became extinct thereafter (not in Table 1). Unlike the Terebratulacea, the Terebratellacea increased from 10 genera in the Jurassic to 40 in the Cretaceous.

Significant changes occurred after the Cretaceous. The rhynchonellids declined from 30 genera in the Cretaceous to 18 in the Tertiary; the terebratulaceans declined to 27 genera in the Tertiary from 67 in the Cretaceous; the cancellothyridaceans from 13 in the Cretaceous to 6 genera in the Tertiary. The terebratellids increased from 40 genera in the Cretaceous to 62 in the Tertiary. The Thecideacea dropped from their maximum of 11 in the Cretaceous to 4 in the Tertiary. The inarticulates numbered 7 genera in the Cretaceous, increasing to 8 in the Tertiary.

Although the Recent brachiopod fauna is thought by some to be a mere remnant of the Tertiary fauna, in reality it numbers 112 genera, nearly as many as the 125 genera of the Tertiary. There is a slight increase (total of 10 genera) of the Inarticulata in the Recent and a slight decrease to 17 genera of the Rhynchonellacea. The Terebratulacea decreased from 27 genera to 19 in the Recent and the Cancellothyridacea increased from 6 Tertiary genera to 10 genera in the Recent fauna. There is a small decline in the number of Recent Terebratellacea to 54 genera in the Recent fauna, in which they are now the most numerous brachiopod element. The Thecideacea declined to 2 genera in the Recent from the 4 present in the Tertiary.

Several Recent genera of the Atlantic and Pacific are not found in Tertiary deposits adjacent to those coasts. Macandrevia occurs off New England but has not yet been found in the Caribbean or East Coast Tertiary. Dallina is fairly common in the Caribbean, rare in the Gulf of Mexico, but has not yet been found as fossil in the Caribbean, East Coast and Gulf Coast Tertiary. It and Macandrevia occur in the Japanese Tertiary.

Ecnomiosa Cooper (1977) from Gulf and Caribbean waters, and also from the Indian Ocean, has not been found as a fossil. Chlidonophora, rare in the Caribbean, common in the Gulf of Mexico, has also been found in the Indian Ocean. Its report as a fossil is probably erroneous. Rare Caribbean forms such as 
Erymnia (Cooper, 1977), Notozyga (Cooper, 1977) and Megerlia are not known from the Caribbean, East Coast, or Gulf Coast Tertiary. Abyssothyris is rare in the North Atlantic, a possible deviant stock, and unknown in the American Tertiary. It occurs with its homeomorphs Notorygmia and Neorhynchia on the Baja Abyssal Plain off San Diego, California. Abyssothyris has been identified from Miocene Globigerina-bearing deposits on Fiji (Cooper 1978). Crania, rare in the Pacific, has not been found in the West Coast Tertiary.

In spite of the changes since the Tertiary, the modern brachiopod fauna is not in serious decline. Widespread modern dredging operations are finding brachiopods at many new locations, with new species and occasional new genera as rewards. Continued exploration for fossil and Recent brachiopods is certain to add many new taxa to the literature.

ACKNowledgments.-Dr. Druid Wilson, retired from the U.S. Geological Survey and well informed in Tertiary stratigraphy and paleontology .advised in connection with recent advances in Tertiary stratigraphy. Dr. J. Thomas Dutro, Jr., U.S. Geological Survey, made valuable suggestions for the improvement of the manuscript. I am most grateful to both of these authorities.

I am grateful to Mr. Rex Doescher, Museum Specialist, for his help with brachiopod ranges. His compilations of genera have been most helpful. Dr. P.M. Kier, formerly curator in the National Museum of Natural History collected many of the brachiopods from South Carolina; Mr. P.J. Harmatuck, Bridgeton, North Carolina, collected most of the specimens from the Ideal Cement Company, northeast of Castle Hayne, North Carolina.

\section{Systematic Hierarchy of Species Described}

(from Class through Species)

Class Inarticulata Huxley, 1869

Order Lingulida Waagen, 1885

Superfamily Lingulacea Menke, 1828

Family Lingulidae Menke, 1828

Genus Glottidia Dall, 1870

Glottidia inexpectans Olsson, 1914

Order Acrotretida Kuhn, 1949

Suborder Craniidina Waagen, 1885

Superfamily Craniacea Menke, 1828

Family Craniidae Menke, 1828

Genus Crania Retzius, 1781

Crania? species 1

Crania? species 2

Genus Isocrania Jaekel, 1902

Isocrania? species 1

Isocrania? species 2

Isocrania? species 3
Order Rhynchonellida Kuhn, 1949

Superfamily Rhynchonellacea Gray, 1848

Family Basiliolidae Cooper, 1959

Subfamily Basiliolinae Cooper, 1959

Genus Probolarina Cooper, 1959

Probolarina brevirostris, new species

Probolarina holmesi santeensis, new subspecies

Probolarina transversa, new species

Order Terebratulida Waagen, 1883

Suborder Terebratulidina Muir-Wood, 1955

Superfamily Cancellothyridacea Thomson, 1926

Family Cancellothyrididae Thomson, 1926

Subfamily Cancellothyridinae Thomson, 1926

Genus Terebratulina d'Orbigny, 1847

Terebratulina alabamensis, new species

Terebratulina brundidgensis Aldrich, 1907

Terebratulina capillata, new species

Terebratulina lachryma (Morton, 1833)

Terebratulina wilsoni, new species

Terebratulina species

Genus Eucalathis Fischer and Oehlert, 1890

Eucalathis? species 1

Eucalathis? species 2

Superfamily Terebratulacea Gray, 1840

Family Terebratulidae Gray, 1840

Subfamily Terebratulinae Gray, 1840

Genus Rhytisoria Cooper, 1983

Rhytisoria alabamensis Cooper, 1983

Subfamily Plicatoriinae Cooper, 1983

Genus Plicatoria Cooper, 1983

Plicatoria wilmingtonensis (Lyell and Sowerby, 1845)

Plicatoria parva, new species

Plicatoria ventricosa, new species

Suborder Terebratellidina Muir-Wood, 1955

Superfamily Terebratellacea King, 1850

Family Megathyrididae Dall, 1870

Genus Argyrotheca Dall, 1900

Argyrotheca beecheri (Clark, 1895)

Argyrotheca laevis, new species

Argyrotheca macneili, new species

Argyrotheca quadrata, new species

Argyrotheca quadrata transversa, new subspecies

Argyrotheca semicostata, new species

Order Thecideida Pajaud, 1970

Suborder Thecideidina Elliott, 1958

Superfamily Thecideacea Gray, 1840

Family Thecideidae Gray, 1840

Subfamily Lacazellinae Backhaus, 1959

Genus Lacazella Munier-Chalmas, 1881

Lacazella nana, new species

Subfamily Thecidellininae Thomson, 1915

Genus Thecidellina Thomson, 1915

Thecidellina alabamensis, new species

Class Articulata Huxley, 1869 


\section{Class Inarticulata Huxley, 1869}

Genera of Inarticulata are generally scarce in the American Tertiary although local occurrence of abundant specimens is known. Lingula, which is usually found in the Southern Hemisphere, has not been found in the Tertiary of the United States. However, its northern cousin, Glottidia is known from the Pliocene of the East Coast Tertiary and from the Miocene and Pliocene of the West Coast Tertiary.

Discradisca Stenzel (1964) is rare in the Paleocene of Texas where its type species, D. littigensis Stenzel occurs. Discradisca lugubris (Conrad) is fairly common in the Miocene of Maryland and Virginia, less so in the Pliocene. Discradisca aldrichi (Gardner) occurs in the Miocene (Alum Bluff Formation) of Florida. Discradisca occurs in the Atlantic where it is rare; it is more common in the Pacific.

In the West Coast Tertiary Discradisca occurs in the Eocene, Oligocene, and Pliocene. Discinisca, the smooth relative of Discradisca, occurs in the Miocene and Pliocene and is fairly common off the west coast of South America.

Crania is rare off the Atlantic coast of the United States. The one specimen described from the Gulf of Mexico has now proved to be a Discradisca (Tunnell, in litt. 17 Sep 1984). Typical, unornamented Crania is not known in the American Tertiary; those referred to Crania with a query are radially ornamented, as is the species from the Paleocene Salt Mountain Formation described by Toulmin (1940).

\section{Genus Glottidia Dall, 1870}

\section{Glottidia inexpectans Olsson, 1914}

Plate 1: Figures 17-32

Glottidia inexpectans O1sson, 1914:21, pl. 12: figs. 17-21.

Large, equivalve, length 2.5 times width; sides subparallel; anterior margin broadly rounded; posterior pointed. Surface marked by fine concentric growth varices. Dark brown with a long median triangular area of lighter brown or grayish brown.

Ventral valve with a long triangular median, elevated, flattened area originating at beak, broadening anteriorly to disappear near anterior quarter. Flanks bounding elevated area gently concave, sloping laterally and marked by concentration of growth varices. Beak sharp, making an angle of about $50^{\circ}$. Interior marked by two diverging ridges, separating posteriorly, each to form small flattened triangle. Ridges diverging anteriorly, extending for slightly less than half shell length. Anterior ends of ridges occupy median $7 \mathrm{~mm}$ of width in a specimen $15 \mathrm{~mm}$ wide. Posterior triangular patches are scars of umbonal muscle attachments. Midvalve marked by low median ridge with scars of central muscles on each side. Anterior quarter with low median ridge, continuation of preceding ridges at midvalve.

Dorsal valve with exterior like that of ventral valve with raised median area and gently concave flanks with crowded growth varices. Inside dorsal valve beak is solid, excavated with umbonal chamber occupied by umbonal muscle scar. Anterior of scar, short median septum extending for slightly more than one-third valve length. Septum ends in splayed anterior from which extends low median ridge nearly to anterior margin. Muscle scars not resolved.

MEASUREMENTS.- - Length and width are in millimeters.

$\begin{array}{lcr}\text { USNM } & \text { Length } & \text { Width } \\ 551520 \mathrm{~b} & & \\ 551520 \mathrm{c} & 32.0 & 12.5 \\ 551520 \mathrm{~d} & 37.0 & 13.5 \\ 551520 \mathrm{~g} & 23.5 & 9.0 \\ 551520 \mathrm{i} & 47.0 & 17.0 \\ 551520 \mathrm{k} & 47.0 & 15.0 \\ 551520-2 & 32.0 & 12.5 \\ 551520 \mathrm{~m} & 18.0 & 7.0 \\ 551520 \mathrm{u} & 34.0 & 15.0 \\ 551520 \mathrm{y} & 45.0 & 17.0 \\ & 40.0 & 17.0\end{array}$

Geological Occurrence.-Pliocene (Yorktown Formation).

LOCALTYY.-Virginia 1.

TYPES.-Hypotypes: USNM 551531; 551520a-z.

Discussion.-The original specimens on which this species is based are very small, $5-12 \mathrm{~mm}$ in length, undoubtedly juveniles. They were taken from the filling of a Pecten jeffersonius shell (Olsson, 1914).

Of described species, $G$. inexpectans is extremely similar externally to G. palmeri Dall (1871). The Pliocene species is slightly wider, averaging $\mathrm{L} / \mathrm{W}=2.62$, while $G$. palmeri has $\mathrm{L} / \mathrm{W}$ above 3.0. The posterior of $G$. palmeri is more pointed and its anterior margin straighter than in $G$. inexpectans. Inside both valves, the interna! ridges of $G$. inexpectans are proportionately shorter, and those of the ventral valve are more widely divergent anteriorly than those of the modern species.

Glottidia is very rare in the fossil state. It is known in the Tertiary of California. The known occurrences of modern Glottidia are on the East and West coasts of North America, the Caribbean, Gulf of Mexico, and Central America.

\section{Genus Crania Retzius, 1781}

The Craniidae have persisted since Ordovician times in a variety of forms, some smooth, some spinose, some pustulose, or moderately costellate, the costellae continuous or discontinuous. Cranias are found in the Tertiary of eastern United States, especially in the Eocene, which, of all the Tertiary on the East Coast, is best endowed with brachiopods. All specimens so far collected from the Eocene of the Coastal Plain have ornamented dorsal valves. Only three ventral valves are known, and these show signs of costellation in the form of small peripheral projections. The younger Tertiary and Pleistocene have not yet yielded Crania, although it may be expected. Crania is not known in the Recent fauna north of Florida. Modern Crania in the western Atlantic usually is concentrically marked; no costellate forms are known. 
Specimens from the Eocene are not common and are usually found in sample residues. They are often small, probably immature forms. Toulmin (1940:288, pl. 28: figs. 1-3) described specimens from the Eocene (Salt Mountain Formation) as Crania species, a costellate form. Sufficient specimens for adequate specific characterization have not yet been found.

\section{Crania? species 1}

\section{Plate 5: Figures 4-6}

Small, widely and roundly elliptical, forming a low eccentric cone in lateral profile. Apex located about one-fifth length from posterior margin. Posterior slope slightly concave; lateral and anterior slopes slightly convex. Surface covered by scattered pits except for the marginal region which is marked by low radial costellae.

Interior marked on the posterior margin by small adductor scars. Posteromedian region bearing $V$-shaped thickening with short median ridge extending anteriorly to slightly anterior of midvalve. Anterior muscle scars present in V-shaped thickening. Inner anterior margin or limbus minutely scalloped except posteriorly.

MEASUREMENTS (mm).-Length 5.5; width 7.1 ; cone height 1.8 .

Geological Occurrence.-Eocene (Castle Hayne Formation).

LoCALITY.-North Carolina 1.

SPECIMEN EXAMINED.-USNM 549401.

\section{Crania? species 2}

PLATE 5: FIGURES 1-3

Subcircular to subquadrangular in outline and conical in profile; apex one-sixth length from posterior margin. Posterior slope steep. Anterior and lateral slopes steep and flattened. Surface marked by densely crowded, discontinuous costellae that form spines at lines of growth interruption and the margin.

Interior with posterior adductor scars well defined and median region not thickened by $V$-shaped mass. Species 1 and 2 of Crania? are unlike any living species.

MEAsUREMENTS (mm).-Length 5.2; width 5.8; cone height 2.3.

Geological Occurrence.-Eocene (Castle Hayne Formation).

LOCALITY.-North Carolina 1.

SPECIMEN EXAMINED.-USNM 549410.

\section{Genus Isocrania Jaekel 1902}

This genus is characterized by having both valves conical, the ventral one attached by its apex and both valves costellate. The costae radiate from the apex to the margins. The adductor scars are well impressed in both valves and there is a short median ridge separating the anterior adductor scars in the ventral valve. There is a strong limbus around the periphery.
The American shells referred to this genus with a query agree in the exterior ornament and in the interior of the dorsal valve. The ventral valve differs from that of Isocrania in having its attachment surface occupying the entire exterior or a generous share of it. The anterior adductor scars of the dorsal valve of the American shells are strongly thickened.

\section{Isocrania? species 1}

Plate 3: figure 8; Plate 6: figures 1, 4

Small, circular in outline, forming shallow cone in profile; apex one-fourth valve length anterior to posterior margin. All slopes gently concave. Surface marked by thin, elevated, thread-like radial costellae separated by wide spaces.

Ventral valve circular, attached by its entire surface; posterior adductor scars large; anterior adductor scars small; short ridge located one-third valve length from posterior margin. Limbus narrow.

MeAsUREMENTS (mm).-Ventral valve: USNM 551512: length 4.7 ; width 6.0 ; height 2.0 ?; dorsal valve: USNM 551509: length 4.8; width 4.8; height about 0.5.

Geological Occurrence.-Eocene (Cross Member of Santee Formation).

LOCALITY.-South Carolina 3.

SPECIMENS EXAMLNED.-USNM 551509, 551510, 551512.

Discussion.-This species is characterized by the low conical form of both valves, the elevated numerous costellae and the septum-like ridge in the ventral valve. Specimen USNM 551512 is regarded as a water worn example.

\section{Isocrania? species 2}

Plate 3: figures 9, 10; Plate 6: figures 2, 3

Small, low cone, elliptical with apex near midvalve. Apical region flattened, smooth, surrounded by concave slopes marked by elevated thread-like costellae without definite pattern. Interior marked by swollen posterior; anterior adductor scars with short low ridge anterior to them.

MEASUREMENTS (mm).-USNM 551528: length 6.3; width 8.3?; height 0.75 ?

Geological Occurrence.-Oligocene (Ashley Member of Cooper Formation).

LOCALITY.-South Carolina 5.

SPECIMENS EXAMINED.-UUSNM 551509, 551528.

Discussion.-The elliptical outline and very flat cone distinguish this species from Isocrania? species 1.

\section{Isocrania? species 3}

A fairly large dorsal valve, length $5 \mathrm{~mm}$ and width about 4.5 $\mathrm{mm}$, and several immature specimens are from the Santee Formation, the former at South Carolina 1 and the immature forms from South Carolina 2. The dorsal valve is irregularly costellate with apex at about one-third valve length. The interior is marked by only a slight thickening of the muscle scars. 
SPECIMENS ExAmINED.-USNM 549403; immature specimens unnumbered.

\section{Class Articulata Huxley, 1869}

\section{Superfamily Rhynchonellacea Gray, 1848}

Rhynchonellids are very rare in the East Coast Tertiary. The small smooth Cryptopora occurs in the Salt Mountain Formation of Alabama (Toulmin, 1940). A single dorsal valve in the USNM collections comes from the Pliocene, SW $1 / 4$ section 16, T. 1 S., R. 4 W., Jacksons Bluff, Ocklocknee River, Florida (USNM 551530). Cryptopora was recently reported living off the Oregon coast (Cooper, 1982). It has not yet been found as a fossil in the West Coast Tertiary.

Hemithiris has been identified in the West Coast Tertiary and East Coast Pleistocene. The generic affinities of the West Coast species are questionable. Eohemithiris, another rhynchonellid of the West Coast Eocene, is living in the southern Pacific but is not known in the Tertiary of the East Coast.

Only new taxa of Probolarina are described here.

\section{Genus Probolarina Cooper, 1959}

\section{Probolarina brevirostris, new species}

Plate 3: Figures 5-7

DIAGNosis.--Small, rotund, with narrow uniplication, low fold and short tongue on ventral valve.

DESCRIPTION.-Small, compact, roundly triangular, length and width nearly equal. Dorsal valve more convex than ventral one. Maximum width at about midvalve. Apical angle $90^{\circ}$. Beak short. Surface costate except for smooth umbones. Costae numbering 16,3 on fold, 2 in sulcus.

Ventral valve gently convex in lateral profile, flatly convex in anterior view. Umbonal and median regions moderately swollen. Sulcus originating at midvalve, widening anteriorly to occupy one-third valve width. Tongue short. Flanks moderately steep, smooth posteriorly.

Dorsal valve strongly convex in lateral profile, strongly domed in anterior view. Umbonal and median regions swollen. Fold low, originating at midvalve. Flanks swollen and steep.

MEASUREMENTS (mm).-USNM 551527: length 7.3; dorsal valve length 6.8; width 7.2; thickness 4.9; apical angle $90^{\circ}$.

Geological OccurRence.-Eocene (Castle Hayne Formation).

LOCALITY.-North Carolina 7.

TYPE.-Holotype: USNM 551527.

Discussion.-This species is similar to Probolarina holmesi (Dall, 1903), also from the Castle Hayne Formation, but is smaller, more compact, with shorter beak, and more pronounced fold and sulcus.

\section{Probolarina holmesi santeensis, new subspecies}

Plate 2: FIGURES 9-17

Diagnosis.-Probolarina with length and width of dorsal valve nearly equal and strongly convex dorsal valve.

DESCRITION.-Small, inequivalve, subtriangular, dorsal valve deeper and more convex than ventral one; maximum width near midvalve; sides rounded, tapering slightly anteriorly; posterolateral margins forming angle of $85^{\circ}$ to slightly over $90^{\circ}$. Lateral commissure nearly straight; anterior commissure uniplicate. Beak very narrow, tube-like; foramen small, hypothyridid, surrounded by alar extensions of conjunct, wholly visible deltidial plates. Surface costate in anterior two-thirds; umbonal regions smooth.

Ventral valve gently convex in lateral profile, flatly convex in anterior view. Umbonal regional narrow, gently convex. Sulcus shallow, originating at midvalve, forming short, anteriorly serrate tongue. Sulcus occupied by 2 to 4 rounded costae; flanks occupied by 2 to 4 costae.

Dorsal valve strongly convex in lateral profile, narrowly and steeply domed in anterior view. Dorsal valve length almost equal to shell width. Umbonal and median regions strongly swollen. Fold beginning at midvalve, not well defined, occupied by 2 to 5 costae. Flanks rounded and steep with 2 to 5 costae.

Ventral valve interior with short erect dental plates, small teeth and sessile pedicle collar. Adductor scar large, surrounded by elongate diductor scars.

Dorsal valve interior with long expanding falcifer crura, crescentic in section and convex laterally. Outer hinge plates narrow, concave. Socket ridges low, sockets long, narrow.

MEASUREMENTS.-All measurements are in millimeters, except apical angles, which are in degrees.

$\begin{array}{lccccc}\text { USNM } & \text { Length } & \begin{array}{c}\text { Dorsal } \\ \text { valve } \\ \text { length }\end{array} & \text { Width } & \begin{array}{c}\text { Thick- } \\ \text { ness }\end{array} & \begin{array}{c}\text { Apical } \\ \text { angle }\end{array} \\ \text { 551518a } & 13.4 & 11.6 & 11.5 & 8.0 & 89 \\ 551518 \mathrm{~b} & 12.5 & 11.3 & 11.0 & 7.8 & 86 \\ 551518 \mathrm{c} & 13.0 & 11.5 & 11.3 & 8.0 & 91 \\ 551518 \mathrm{~d} & 11.2 & 10.0 & 9.8 & 6.8 & 85 \\ 551518 \mathrm{e} & 11.0 & 9.8 & 9.7 & 7.0 & 86\end{array}$

Geological OcCurRenCE.-Eocene (Santee Formation).

LOCALITY.-South Carolina 2.

TYPES.-Holotype: USNM 551518a; paratypes: USNM $551518 \mathrm{~b}-\mathrm{n}$.

Discussion.-This subspecies has the same narrowly triangular form as Probolarina holmesi (Dall, 1903) from the Castle Hayne Formation at Wilmington but differs in its larger size, less development of a pedicle collar, the shell more strongly costate, and costae extending for two-thirds shell length. It is less wide and thicker than $P$. transversa, new species. 


\section{Probolarina transversa, new species}

Plate 2: figures 30-46

\section{Diagnosis.-Widely triangular Probolarina.}

DESCRIPTION.-Smali, widely triangular in outline; maximum width anterior of midvalve; inequivalve, dorsal valve more convex than ventral one. Sides somewhat narrowly rounded. Anterior margin gently convex; posterolateral extremities forming angle of slightly more or slightly less than $90^{\circ}$. Beak narrow, foramen oval, small, hypothyridid; deltidial plates conjunct, alate, forming short tube. Lateral commissure nearly straight; anterior commissure gently uniplicate. Surface semicostate, costae in anterior half, posterior half smooth. Number of costae variable, from 8 to 12, with 2-5 in the sulcus and 3-6 on the fold, 4-6 on flanks.

Ventral valve slightly convex in lateral view, broadly and gently convex in anterior profile. Beak narrow, umbonal median regions gently swollen; sulcus beginning abruptly at about midvalve, shallow, forming short serrate tongue. Flanks with gentle slopes, occupied by 4 costae.

Dorsal valve fairly strongly convex in lateral view, broadly and moderately domed in anterior profile. Umbo smooth, swollen, swelling continued anteriorly as low fold, slightly elevated above steep, rounded flanks.

Ventral valve interior without pedicle collar (?); dental plates short, erect; umbonal chambers separating dental plates from shell wall narrow. Muscle scars not seen.

Dorsal valve interior with broad falcifer crura. Other details not seen.

MEASUREMENTs.-All measurements are in millimeters, except apical angles, which are in degrees.

$\begin{array}{lcrrcc}\text { USNM } & \text { Length } & \begin{array}{c}\text { Dorsal } \\ \text { valve } \\ \text { length }\end{array} & \text { Width } & \begin{array}{c}\text { Thick- } \\ \text { ness }\end{array} & \begin{array}{c}\text { Apical } \\ \text { angle }\end{array} \\ 551517 \mathrm{a} & 10.7 & 9.4 & 11.4 & 6.3 & 92 \\ 551517 \mathrm{~b} & 10.8 & 9.6 & 9.8 & 6.4 & 92 \\ 551517 \mathrm{c} & 12.3 & 11.0 & 12.0 & 6.5 & 87 \\ 551517 \mathrm{f} & 10.9 & 9.6 & 10.0 & 6.0 & 92\end{array}$

Geological OccurrencE.-Eocene (Santee Formation).

LOCALITY.-South Carolina 2.

TYPES.-Holotype: USNM 551517a; paratypes: USNNM 551517b-f.

Discussion.-This species differs from Probolarina holmesi santeensis, new subspecies, in the nearly equal dimensions of its length and width, whereas the subspecies is more narrowly triangular with length greater than width and with greater thickness. Probolarina transversa, new species, differs from P. salpinx (Dall, 1903) in having narrower costae in the fold and sulcus.

\section{Superfamily Cancellothyrdacea Thomson, 1926}

As in modern seas, Terebratulina is common in the Tertiary of the world. It is present in the Eocene of New Jersey ( $T$. manasquani Stenzel, 1940), in Alabama (T. brundidgensis, Aldrich 1907, T. innovata de Gregorio, 1890), in Louisianna (T. louisianensis Stenzel, 1940), in South Carolina ( $T$. lachryma Morton, 1833) and in North and South Carolina (the new species described herein). Terebratulina occurs in all epochs of the West Coast Tertiary and is extant off the West Coast, where it is fairly common. It is common off the New England coast and in the Caribbean Sea, less common in the Gulf of Mexico. It is a long-lived genus, from Jurassic to Recent and is worldwide in its distribution.

Eucalathis is known from the Caribbean and is widely distributed, usually in deep water. It is rare and doubtfully identified in the East Coast Tertiary. It is not known in the West Coast Tertiary nor in the northern Pacific.

\section{Genus Terebratulina d'Orbigny, 1847}

Terebratulina alabamensis, new species

$$
\text { Plate 6: figures 5-13 }
$$

Diagnosis.-Small Terebratulina with width about $80 \%$ or more of length, and with concentric growth varices.

DESCRIPTION.-Small, widely oval, longer than wide, subequivalve, greatest width anterior to midvalve; anterior truncate; posterolateral extremities forming an angle of $80^{\circ}-90^{\circ}$ in the adult. Lateral commissure straight; anterior commissure rectimarginate. Beak short, truncated; foramen fairly large; deltidial plates small. Surface costellate with strong growth varices. Costellae increasing by bifurcation and intercalation in three generations; costellae strongest posteriorly, fairly uniform anteriorly with about 4 in a millimeter at the anterior of shells 10-12 mm long.

Ventral valve evenly and moderately convex in lateral view, broadly and moderately domed in anterior view. Umbonal and median regions swollen; anterior flattened.

Dorsal valve less convex in lateral profile than ventral valve, anterior profile moderately narrowly domed, more so than ventral valve. Anterior flattened; ears conspicuous.

Ventral valve interior with short, excavate pedicle collar, iarge teeth. Muscle scars lightly impressed.

Dorsal valve interior with stout loop one-third valve length. Socket ridges straight, obliquely directed crura and stout ring.

MEAsUREMENTs.-All measurements are in millimeters, except apical angles, which are in degrees.

$\begin{array}{lcrrrr}\text { USNM } & \text { Length } & \begin{array}{c}\text { Dorsal } \\ \text { valve } \\ \text { iength }\end{array} & \text { Width } & \begin{array}{c}\text { Thick- } \\ \text { ness }\end{array} & \begin{array}{c}\text { Apical } \\ \text { angle }\end{array} \\ 141028 \mathrm{a} & 11.6 & 10.9 & 10.4 & 5.4 & 84 \\ 141028 \mathrm{~b} & 12.2 & 11.6 & 10.5 & 4.8 & 86 \\ 141028 \mathrm{e} & 10.3 & 9.9 & 9.4 & 4.6 & 88 \\ 141028 \mathrm{f} & 12.5 & 11.7 & 10.1 & 5.0 & 90 \\ 141028 \mathrm{~h} & 11.0 & 10.4 & 9.6 & 4.6 & 88\end{array}$

GeOlOGiCAL CCCURRENCE.-Oligocene (Jackson Group, Zeuglodon Bed; and Jackson Group). 
LOCALITIES.-Alabama 2, 5, 7 .

TYPES.-Holotype USNM 141028a; paratypes: USNM 141028b-h.

Discussion.-This Jackson Group species has been called T. lachryma (Morton, 1833), but it differs markedly from that species in its greater width, greater frequency of occurrence, and strength of its growth varices and shorter beak. Terebratulina brundidgensis Aldrich, 1907, is widest near midvalve, is more elongate, and more strongly costellate than T. alabamensis. The latter differs from $T$. wilsoni, new species, in its wider outline, flatter shells, and more prominent growth varices.

\section{Terebratulina brundidgensis Aldrich, 1907}

Plate 1: figures 9-14; Plate 3: figures 1-4, 16-19

Terebratulina brundidgensis Aldrich, 1907:8, pl. 1: figs. 1-3.

About medium size, longer than wide, oval in outline; inequivalve, ventral valve deeper than dorsal valve; sides rounded; maximum width anterior to midvalve; anterior margin strongly rounded. Posterolateral margins forming angle of about $70^{\circ}$. Lateral commissure straight; anterior commissure rectimarginate. Beak narrow, moderately extended; deltidial plates small. Surface multicostellate, early costellae narrowly rounded, coarse at umbones, increasing by intercalation. First intercalation just anterior to beaks, second at about $2 \mathrm{~mm}$ on ventral valve, third at or near midvalve, and fourth in anterior third.

Ventral valve gently convex in lateral view; anterior profile broadly domed. Umbonal region narrowly convex; median region moderately swollen; anterior slope flattened.

Dorsal valve flatly convex in lateral profile; gently domed in anterior view. Umbonal region narrow; median region gently inflated.

Dorsal valve interior with loop occupying nearly half valve length; crura stout; ring ribbons wide; ring diameter $1.3 \mathrm{~mm}$, about one-fourth valve width.

MEASUREMENTS.-All measurements are in millimeters, except apical angles, which are in degrees.

$\begin{array}{lrrrrr}\text { USNM } & \text { Length } & \begin{array}{c}\text { Dorsal } \\ \text { valve } \\ \text { length }\end{array} & \text { Width } & \begin{array}{c}\text { Thick- } \\ \text { ness }\end{array} & \begin{array}{c}\text { Apical } \\ \text { angle }\end{array} \\ 551519 \mathrm{a} & 15.3 & 13.6 & 12.0 & 5.3 & 71 \\ 551519 \mathrm{~b} & 14.3 & 12.7 & 10.8 & 5.5 & 71 \\ 551519 \mathrm{c} & 14.2 & 13.0 & 10.2 & 5.0 & 67 \\ 551519 \mathrm{~d} & 13.4 & 12.1 & 10.1 & 5.3 & 69 \\ 551519 \mathrm{e} & 11.0 & 10.0 & 8.4 & 4.3 & 72 \\ 639036^{*} & 9.5 & 8.3 & 7.0 & 3.2 & 69 \\ 639037^{* *} & 15.2 & 13.8 & 11.4 & 7.3 & 71 \\ 639038^{* *} & 12.8 & 11.3 & 9.8 & 5.3 & 81\end{array}$

* Lectotype.

**Paralectotype.

Geological Occurrence.-Paleocene (Wilcox Group, unnamed limestone below the Nanafalia Formation).
LOCALITY.-Alabama 1.

TYPES.-Lectotype: USNM 639036; paralectotypes: USNM 639037, 639038; hypotypes: USNM 551519a-e.

Discussion.-This species is based on three syntypes (USNM 639036-639038); all three unlike in size and preservation, two of them deviating strongly from the average of a collection of 45 specimens from the type locality. Specimen USNM 639036 is small, about half grown, but all its features are like those of the lot of 45 specimens (USNM 551519). Specimen USNM 639037 is aberrant as regards thickness. Its ornament is badly worn so that the specimen appears finely costellate. Specimen USNM 639038 is unlike the other two and unlike any in the collection. It is widest at midvalve rather than anterior to it and its apical angle is greater than that of any other specimen in the collection. In addition, the dorsal valve bears a narrow median furrow occupied by a single costella at its place of initiation near midvalve, becoming smaller and joined by implantation of a costella on each side just anterior to midvalve and extending to the anterior margin. On the ventral valve the narrow sulcus is opposed by a primary costa and a second intercalated costa adjacent, both of these become enlarged as two tight bundles of costellae. Aldrich (1907:8) described these as "a central raised rib doubled shows on the ventral valve, replaced by a depression between two ribs on dorsal valve ...." Nothing like this is seen on any other specimen in the collection; it appears to be a unique aberration.

Aldrich failed to designate a type specimen. His mention of the raised double rib suggests that, in his opinion, this was the most important specimen in the lot. Because this specimen is unlike any other from the same locality and formation, it has not been selected as lectotype. Specimen USNM 639036, although a young one, agrees with specimens in the lot of 45 and is therefore here chosen as lectotype.

According to Stenzel (1943, card 133) this species is known only from the type locality. Terebratulina brundidgensis Aldrich 1907, differs from T. capillata, new species, and $T$. lachryma in its stronger costellation and flattened valves. It differs from T. alabamensis, new species, in its larger size, more ovoid outline, stronger costellation, and lack of strong growth varices.

\section{Terebratulina capillata, new species}

Plate 3: figures 37-41; Plate 5: figures 7-11, 29-40

DiAGNosis.-Uniplicate, finely capillate Terebratulina with short beak and stout loop.

DESCRIPTION.-Medium size, oval, longer than wide, maximum width at or slightly anterior to midvalve; sides rounded; anterior margin narrowly rounded; posterolateral margins forming angle of $80^{\circ}-90^{\circ}$ in adult. Lateral commissure moderately concave toward ventral side; anterior commissure uniplicate in large adults. Beak suberect, strongly truncated. Foramen large; deltidial plates small. Surface marked by fine, elevated, thread-like crowded costellae, 4 to 5 in $1 \mathrm{~mm}$ at anterior. Costellae minutely beaded on posterolateral slopes. 
Ventral valve gently convex in lateral profile, broadly but gently convex in anterior profile. Umbonal region swollen to about midvalve, flattening or becoming gently concave anteriorly to form a poorly defined sulcus. Ventral tongue short. Flanks bounding sulcus convex; posterolateral slopes short, concave.

Dorsal valve about equal in depth to ventral valve; flatter in lateral profile than ventral valve but considerably more convex than that valve in anterior view. Ears very small. Umbonal region narrowly swollen, swelling continued anteriorly to form moderately strong fold. Lateral slopes long, fairly steep.

Dorsal valve interior with erect, slender socket ridges that project slightly beyond posterior margin. Crura stout, bowed outward, supporting strong ring consisting of moderately broad posterior band and ventrally projecting transverse band.

MEASUREMENTS.-All measurements are in millimeters, except apical angles, which are in degrees.

$\begin{array}{lrrrrc}\text { USNM } & \text { Length } & \begin{array}{c}\text { Dorsal } \\ \text { valve } \\ \text { length }\end{array} & \text { Width } & \begin{array}{c}\text { Thick- } \\ \text { ness }\end{array} & \begin{array}{c}\text { Apical } \\ \text { angle }\end{array} \\ \text { 550814a } & 17.3 & 16.5 & 14.3 & 8.1 & 90 \\ 550814 \mathrm{~b} & 14.0 & 12.6 & 11.2 & 6.8 & 81 \\ 550814 \mathrm{c} & 11.5 & 10.6 & 9.1 & 5.3 & 86 \\ 550814 \mathrm{~d} & 9.1 & 8.3 & 7.5 & 3.4 & 88\end{array}$

Geological OccurRence.-Eocene (Castle Hayne Formation).

LOCALITY.-North Carolina 1.

TYPES.-Holotype: USNM 550814b; paratypes: 550814a,ci; 550872, 550882a-e, 551525a.

Discussion.-This species has been known hitherto as Terebratulina lachryma (Morton, 1833), but it is wider, more strongly uniplicate, and has a stouter loop. It is also larger and more evenly and finely costellate than $T$. brundidgensis Aldrich, 1907, from Alabama. Although its shape is similar to that of T. manasquani Stenzel, 1940, it is much smaller, more finely costellate and not so strongly folded as that species. It is suggestive of T. louisianae Stenzel, 1943, but that species has a larger foramen, more prominent ears, and appears not to be uniplicate. Terebratulina capillata differs from T. wilsoni, new species, in its larger size, wider outline, and less umbonate dorsal valve.

Lot USNM 550882 from the Castle Hayne Formation at Wilmington, North Carolina, contains many small specimens of Terebratulina that I believe are the young of $T$. capillata. These variable, small specimens have been regarded hitherto as belonging to Terbratulina lachryma (Morton) because of their small size. The shape of these small terebratulinas is variable, some well rounded but others more elongated. Many of them have strongly beaded costellae (Plate 5: figures 7-11), a characteristic of most immature terebratulinas. The beaded nature of the costellae in many species of Terebratulina is not retained in the adult, probably due to abrasion. Some adults do maintain traces of the beads in the region around the ears, which is usually protected. A few adults of $T$. capillata retain traces of the beaded costellae in the posterior regions.

Beading in the Wilmington specimens is variable as is the costellation in the earliest stages. Some young either did not form beaded costellae at the earliest stages of the shells, died early, and, being the prey of currents, had the beads abraded.

\section{Terebratulina lachryma (Morton, 1833)}

Figures 1, 2; Plate 1: Figure 16; Plate 3: Figures 11-15;

Plate 5: Figures 26-28; Plate 6: Figures 14-28

Terebratula lachryma Morton, 1833:130, pl. 10: fig. 11; 1834:17, pl. 16: fig. 6. Terebralulina lachryma (Morton).-Whitfield 1885:12, pl. 1: fig. 14.Stenzel, 1943, card 135.

DESCRIPTION.--Medium size, longer than wide, narrowly oval; sides rounded; maximum width at midvalve. Anterior margin narrowly rounded; posterolateral margins forming angle of $58^{\circ}-82^{\circ}$. Lateral commissure gently curved toward the ventral side; anterior commissure rectimarginate to faintly uniplicate. Beak short, truncated; foramen large; deltidial plates small. Surface finely costellate, costellae strongest at posterior, increasing by bifurcation and implantation in 5 generations; 6 costellae in $1 \mathrm{~mm}$ at anterior margin; 4 in $1 \mathrm{~mm}$ at midvalve of a specimen $14 \mathrm{~mm}$ long.

Ventral valve moderately and gently convex in lateral profile and anterior view, less convex than dorsal valve in same views. Umbonal region well rounded and swollen, swelling extending

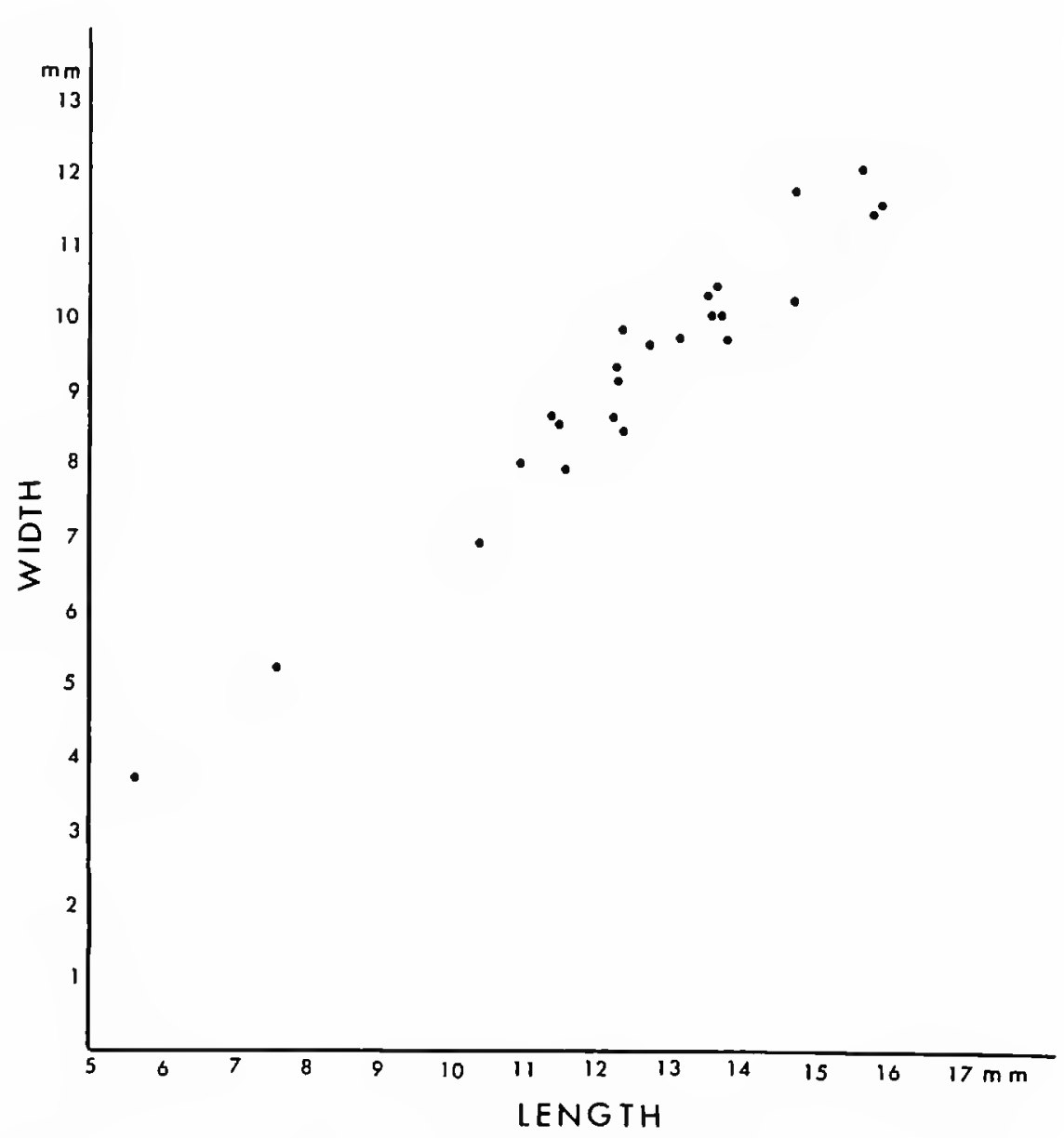

FIGURE 1.-Scattergram showing width/length relationship of 24 specimens of Terebratulina lachryma (Morton) from South Carolina locality 2. 


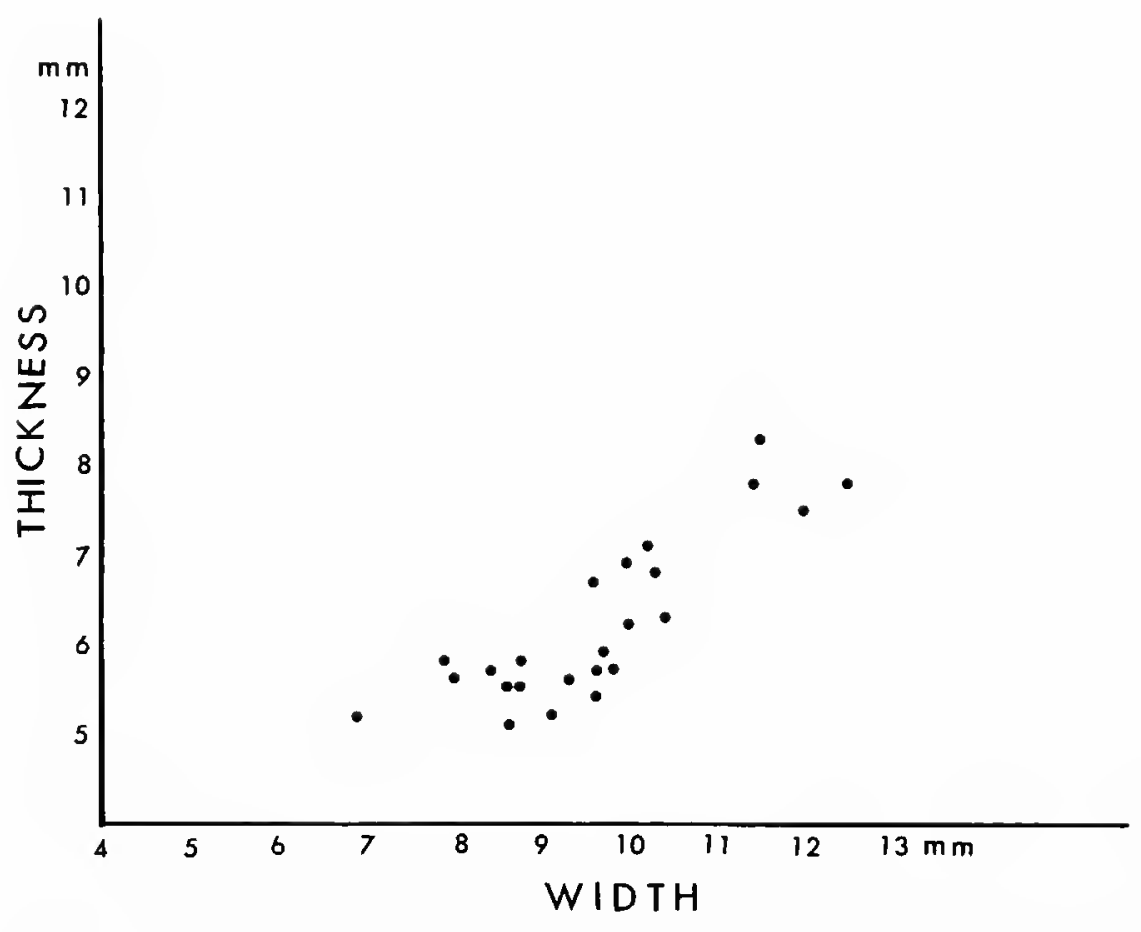

FIGURE 2.-Scattergram showing thickness/width relationship of 24 specimens of Terebratulina lachryma (Morton) from South Carolina locality 2.

to midvalve, dissipating anteriorly with flattening of shell. Posterolateral slopes rounded and steep. Interarea narrow.

Dorsal valve more convex than ventral valve in umbonal region in lateral view; anterior profile narrowly domed with long steep slopes. Umbonal and median regions swollen; anterior half flattened.

Ventral valve interior with large teeth and short, excavate pedicle collar.

Dorsal valve interior with fairly large elliptical cardinal process; socket ridges short, thin; crura slender, bowed; ring small, delicate, not complete in some fully grown specimens, complete in some only $9 \mathrm{~mm}$ long.

MEASUREMENTS.-All measurements are in millimeters, except apical angles, which are in degrees; questionmark indicates angle could not be measured.

$\begin{array}{lccccc}\text { USNM } & \text { Length } & \begin{array}{c}\text { Dorsal } \\ \text { valve } \\ \text { length }\end{array} & \text { Width } & \begin{array}{c}\text { Thick- } \\ \text { ness }\end{array} & \begin{array}{c}\text { Apical } \\ \text { angle }\end{array} \\ 551516-25 & 16.2 & 15.5 & 12.5 & 7.8 & 82 \\ 551516-24 & 16.0 & 14.5 & 11.5 & 8.3 & 66 \\ 551516-23 & 15.9 & 14.5 & 11.4 & 7.8 & 74 \\ 551516-18 & 14.8 & 13.5 & 10.2 & 7.1 & 70 \\ 551516-12 & 13.7 & 12.6 & 10.4 & 6.3 & 70 \\ 551516-22 & 11.6 & 10.5 & 7.9 & 5.8 & 62 \\ 551516-26 & 10.2 & 9.1 & 7.3 & 5.0 & 69 \\ 551516-27 & 7.6 & 7.0 & 5.2 & 3.6 & 65 \\ 551516-28 & 5.6 & 5.0 & 3.7 & 2.5 & ?\end{array}$

Geological OccurRENCE.-Eocene (Santee Formation). LOCALITIES.-South Carolina 1, 2.

TYPES.-Hypotypes: USNM 550883a,b; 551514a-e; 551516ad; 551516-1-28; 551526a.

Discussion.-Terebratulina lachryma (Morton) differs from T. capillata, new species, chiefly in its narrow form, lesser apical angle and more delicate loop. Occasional large specimens of $T$. lachryma, such as USNM 551516-25, approach adult $T$. capillata in size and general appearance, but the bulk of the specimens have a smaller apical angle and more slender form. (See discussion under $T$. wilsoni, new species, for distinction between the two species.)

\section{Terebratulina wilsoni, new species}

Figures 3, 4; Plate 1: figure 15; Plate 6: figures 29-36

Diagnosis.-Medium size Terebratulina, widest at midvalve and with ears obsolete.

DESCRIPTION.-Medium size, oval, longer than wide; maximum width at midvalve; dorsal valve slightly deeper than ventral one; sides rounded, anterior margin narrowly rounded; posterolateral extremities forming angle of $67^{\circ}-91^{\circ}$. Lateral commissure gently concave toward the ventral side; anterior commissure rectimarginate to gently uniplicate. Beak short, truncated; foramen small, deltidial plates small. Surface variably multicostellate, costellae intercalated in five generations; strongest posteriorly, becoming flattened and often obscure anteriorly.

Ventral valve evenly and moderately convex in lateral profile, broadly and gently convex in anterior view. Umbonal region narrowly swollen, swelling continued to midvalve, flattened in anterior third to half to produce indistinct sulcus. Flanks bounding posterolateral margins rounded.

Dorsal valve moderately convex in lateral view, slightly more so than the ventral valve, narrowly humped in anterior view. Umbonal region swollen, swelling continued to anterior margin forming narrow fold and somewhat nasute anterior. Flanks steep; ears much reduced.

Ventral valve interior with short anteriorly excavate pedicle collar, elongate teeth; muscle scars lightly impressed.

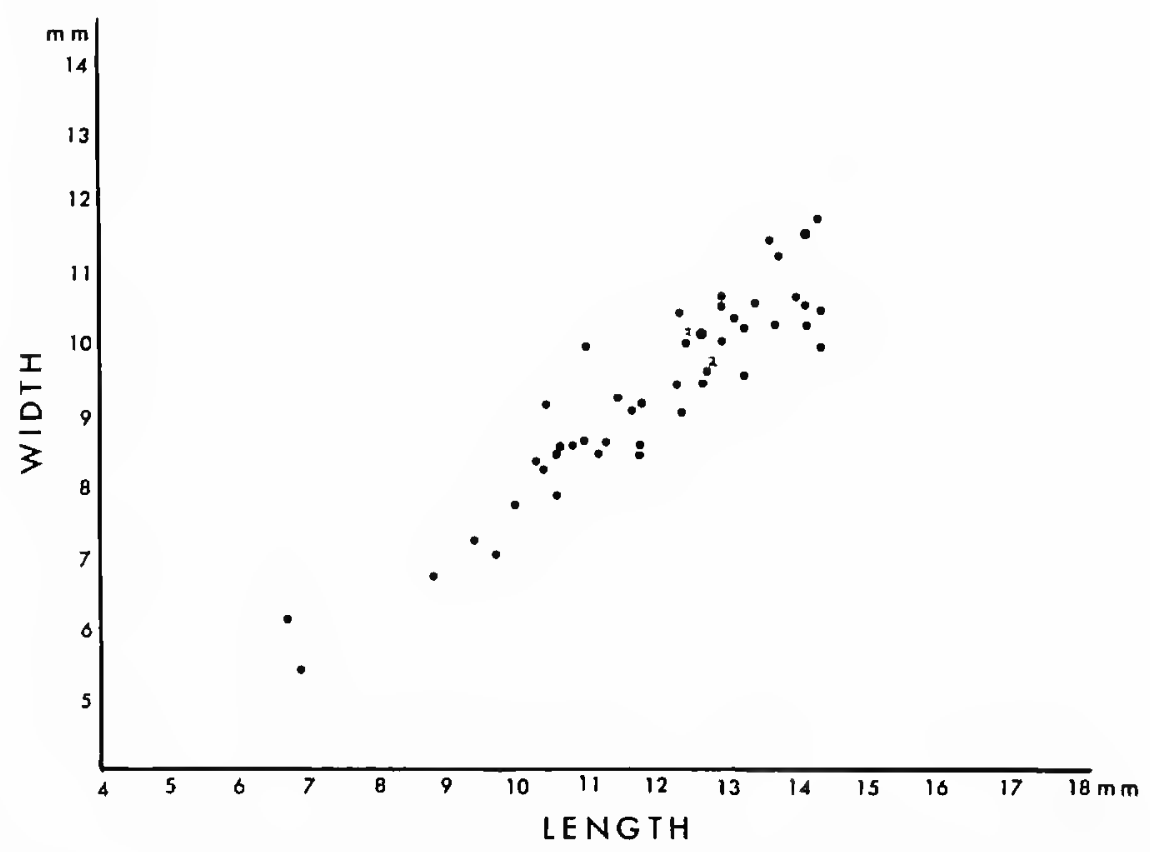

FIGURE 3.-Scattergram showing width/length relationship of 51 specimens of Terebratulina wilsoni, new species, from South Carolina locality 4. (The digit " 2 " over a dot indicates 2 specimens.) 


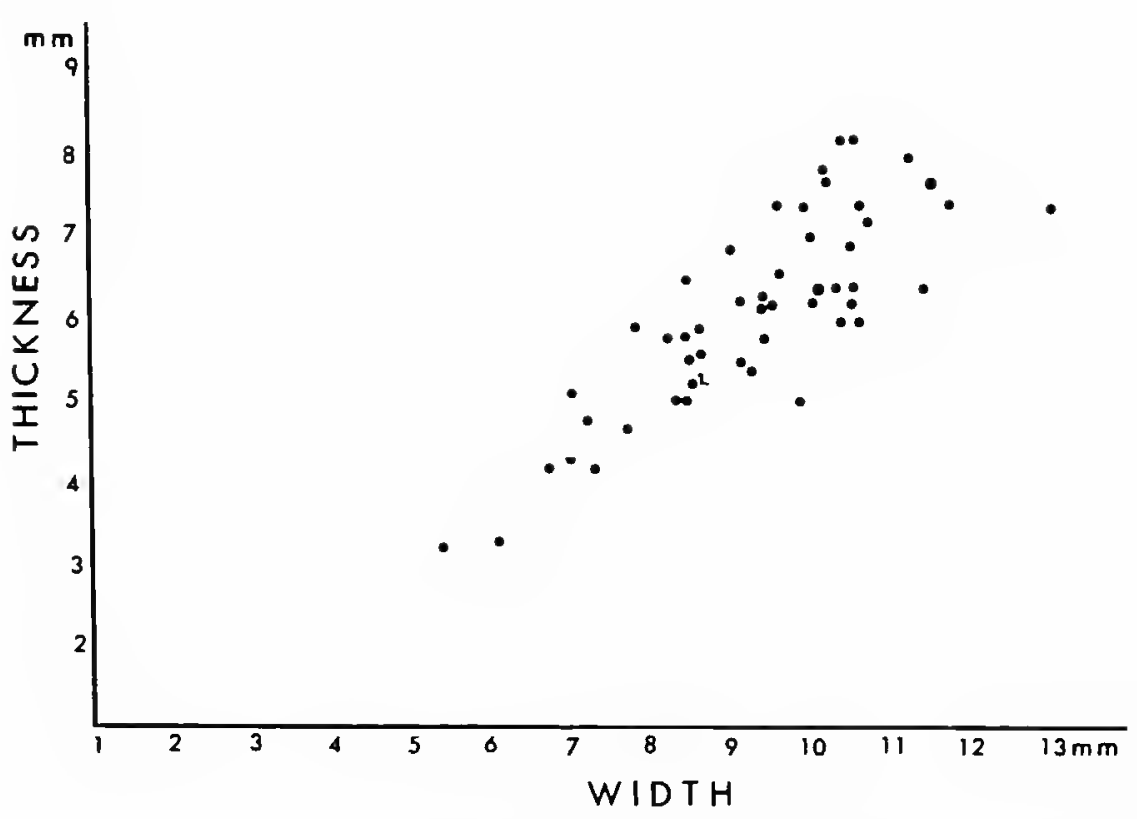

FIGURE 4.-Scattergram showing thickness/width relationship of 51 specimens of Terebralulina wilsoni, new species, from South Carolina locality 4. (The digit " 2 " over a dot indicates 2 specimens.)

Dorsal valve with short, erect socket ridges extended posteriorly; cardinal process small; 'loop about one-third valve length, about one-fourth its width; crura widely bowed; crural processes small, sharply pointed in some specimens, coalesced to form small ring in older specimens. Pedicle muscle scars narrow, elongate, separated by low ridge; adductor scars elongate, reaching midvalve.

MEASUREMENTS.-All measurements are in millimeters, except apical angles, which are in degrees.

$\begin{array}{lccccc}\text { USNM } & \text { Length } & \begin{array}{c}\text { Dorsal } \\ \text { valve } \\ \text { length }\end{array} & \text { Width } & \begin{array}{c}\text { Thick- } \\ \text { ness }\end{array} & \begin{array}{c}\text { Apical } \\ \text { angle }\end{array} \\ \text { 551515a } & 14.2 & 12.5 & 11.5 & 7.7 & 84 \\ 551515 \mathrm{~b} & 12.7 & 11.3 & 10.1 & 6.4 & 83 \\ 551515-1 & 14.8 & 13.3 & 13.0 & 7.4 & 91 \\ 551515-5 & 13.8 & 12.2 & 10.2 & 7.7 & 76 \\ 551515-7 & 12.8 & 11.0 & 9.6 & 7.4 & 75 \\ 551515-21 & 11.7 & 10.5 & 9.0 & 6.2 & 75 \\ 551515-24 & 10.0 & 8.6 & 7.7 & 4.7 & 77 \\ 551515-42 & 8.6 & 7.6 & 7.3 & 4.2 & 83 \\ 551515-26 & 6.7 & 5.7 & 6.1 & 3.3 & 83\end{array}$

Geological Occurrence.-Eocene (Cross member of the Santee Formation).

LoCALITIES.-South Carolina 3, 4.

TYPES.-Holotype: USNM 551515a; paratypes: USNM 551513; 551515b,c; 551515-(1-50).

Discussion.-This is a variable species with a small percentage of specimens having a shallower, wider valve than the majority. Very young specimens often have beaded costellae, especially in the posterolateral regions, and welldefined dorsal ears that are much reduced in the adult.

In the growth of the shell, there is intercalation of costellae at a very early stage. On a specimen $1.5 \mathrm{~mm}$ long, all of the $10-12$ costellae are direct. A specimen $2.5 \mathrm{~mm}$ long has a first generation of intercalated costellae at about $2 \mathrm{~mm}$. A specimen $4.5 \mathrm{~mm}$ long has bifurcation as well as intercalation of costellae at about midvalve. In a specimen $5 \mathrm{~mm}$ long another set of costellae appears, and a specimen $7.5 \mathrm{~mm}$ long has 3 intercalations.

This species differs from T. lachryma (Morton) in its more convex valves when viewed from the anterior, its undefined dorsal valve ears, narrower anterior, and finer ornament, especially on the anterior parts. It differs from $T$. capillata, new species, in its generally smaller size, more inflated dorsal valve and narrower oval outline. It differs from $T$. brundidgensis Aldrich and T. alabamensis, new species, in its quite different ornament from that of the other two.

Named in honor of Dr. Druid Wilson whose great knowledge of the Tertiary of eastern United States has helped me in preparation of this manuscript.

\section{Terebratulina species}

Plate 3: figures 20-29

DESCRPTION.-Small, oval, sides and anterior rounded, posterolateral margins forming angle of $80^{\circ}-90^{\circ}$. Ventral valve deeper than dorsal one. Anterior commissure rectimarginate. Surface costellate in 4 generations. Loop with stout, subparellel crura and narrow ring.

MEASUREMENTS.-All measurements are in millimeters, except apical angles, which are in degrees.

$\begin{array}{lrrllll}\text { USNM } & \text { Length } & \begin{array}{c}\text { Dorsal } \\ \text { valve } \\ \text { length }\end{array} & \text { Width } & \begin{array}{c}\text { Thick- } \\ \text { ness }\end{array} & \begin{array}{c}\text { Apical } \\ \text { angle }\end{array} \\ \text { 145613a } & 10.4 & 9.4 & 8.2 ? & 4.6 & 81 \\ 145613 \mathrm{~b} & 11.6 & 10.5 & 8.8 & 5.4 & 84 \\ 145613 \mathrm{c} & 8.9 & 8.9 & 7.6 & 3.5 & 90\end{array}$

Geological OccurRence.-Oligocene (Jackson Group). LOCALTTY.-Alabama 6.

SPECIMENS EXAMINED.-USNM 145613a-d.

Discussion.-Most of the specimens of this species are distorted by crushing. An uncrushed specimen (USNM $145613 \mathrm{~b}$ ) indicates a less rotund species than $T$. alabamensis, new species, large specimens of which tend toward a circular outline. Terebratulina species does not tend to the elongate oval form of T. lachryma (Morton), although these specimens were originally placed in that species.

\section{Genus Eucalathis Fischer and Oehlert, 1890}

Specimens of Eucalathis? are uncommon and the generic identification is uncertain because the nature of the loop has not been determined. The relatively wide hinge of the specimens noted below is suggestive of Eucalathis rather than Terebratulina, and the specimens differ strongly in shape and ornamentation from the young of Terebratulina. Eucalathis is widespread in modern seas and can be expected in the Tertiary. 


\section{Eucalathis? species 1}

Plate 5: FIGURES $41-44$

Small, rotund, length and width nearly equal; sides and anterior rounded; maximum width at midvalve; hinge narrower than maximum shell width. Apical angle $100^{\circ}$. Lateral commissure straight; anterior commissure rectimarginate. Beak extended; interareas narrow. Delthyrium open, deltidial plates not resolved. Surface costate, costae numbering 16 major costae with short ones intercalated at the margin.

Ventral valve slightly more convex than dorsal one; moderately convex in lateral view, broadly domed in anterior view. Median and umbonal regions swollen.

Dorsal valve gently convex in lateral view, broadly, moderately domed in anterior view. Median region swollen. Cardinal extremities forming small ears with beaded posterior margin.

MeAsurements (mm).-USNM 551511: length 2.5; dorsal valve length 2.1 ; hinge width 1.6 ; width 2.3 ; thickness 1.2 ; apical angle $100^{\circ}$.

Geological Occurrence.-Eocene (Cross Member of the Santee Formation).

LOCALITY.-South Carolina 3.

SPECIMEN EXAMINED.-USNM 551511.

Discussion.-This specimen differs from the young of Terebratulina in its direct costation, rotund valves, and wider hinge. It differs from Eucalathis species 2 in its finer costation and shape of the valves.

\section{Eucalathis? species 2}

Plate 5: Figures 45-50

Small, subpentagonal, slightly longer than wide; dorsal valve more convex than ventral one; hinge narrower than maximum width at midvalve; both commissures straight. Sides and anterior margin rounded; apical angle $100^{\circ}$. Beak extended; interareas narrow. Deltidial plates not resolved. Delthyrium wide. Surface costate; costae wide, subangular, numbering 11 at anterior margin. Ventral valve costae prominently beaded in posterior two-thirds; dorsal valve not beaded.

Ventral valve gently convex in lateral view; gently domed in anterior profile. Umbonal and median regions swollen. Anterior third flatly convex. Interior with long pedicle collar and large teeth. Anterior margin corrugate.

Dorsal valve fairly strongly convex in side view especially in umbonal and median regions, flattening anteriorly. Ears flattened, not prominent. Interior with characteristic cancellothyridid socket ridges.

MEASUREMENTS (mm).-USNM 550886a: length 2.5; dorsal valve length 2.0 ; hinge width 1.6 ; width 2.2 ; thickness 1.4 ; apical angle $100^{\circ}$.

Geological Occurrence.-Eocene (Castle Hayne Formation).

LOCALITY.-North Carolina 1.
SPECIMENS EXAMINED.-USNM 550886a-c.

Discussion.-The strong and sparse costation of the valves sets this species aside from any of the young of Terebratulina. It also differs from Eucalathis species 1 in its stronger costation, beaded ventral valve and different proportion of the valves.

\section{Superfamily Terebratulacea Gray, 1840}

All of the Terebratulacea of the East Coast Tertiary are extinct. Oleneothyris, with two species, from the Paleocene of New Jersey, Delaware, Maryland, and North Carolina, is our largest Tertiary terebratulid. Its loop and folding are distinctive. Rhytisoria from the Paleocene of Alabama, recently described by Cooper (1983), is a rare form with distinctive folding and loop different from that of Oleneothyris, and the three genera of terebratulids from the Eocene (Castle Hayne Formation) of North Carolina.

The Eocene (Castle Hayne Formation) yielded rare specimens of Embolosia, a narrow elongate genus, Tanyoscapha, a large smooth, wide form, and Plicatoria, a variously folded genus. The three have similar loops with long outer hinge plates and the crural processes located just posterior of the transverse band.

Tertiary specimens called Terebratula coming from outside the Mediterranean region are probably incorrectly identified. On the West Coast, several species are incorrectly referred to Terebratula, their true identify unknown. Kellum (1926) described Terebratula crassa (later renamed Terebratula posteriora by Kellum in 1931) from the Castle Hayne Formation. Kellum's species has different cardinalia from those of Tanyoscapha. There is some resemblance of the cardinalia of Kellum's species to those of Oleneothyris, but the loop and folding of $T$. posteriora are unknown and its true relationships cannot now be stated.

\section{Genus Plicatoria Cooper, 1983}

\section{Plicatoria wilmingtonensis (Lyell and Sowerby, 1845)}

Figures 5-11; Plate 2: figures 18-29; Plates 7, 8; Plate 9: figures 1-40

Terebratula wilmingtonensis Lyell and Sowerby, 1845:431, fig. b.-Conrad, 1865:15.-Dall, 1903[pan]:1537, pl. 58: figs. 14-17 [not 18-20].-Kellum, 1926:7.-Henlein and Grant, 1944:86.

Terebratula demissirostra Conrad, 1875:18, pl. 3: fig. 1, [7?].

Terebratula canipes sensu Stenzel, 1943, card 129 [not Terebratula canipes Ravenel, 1844].

Plicatoria wilmingtonensis (Lyell and Sowerby).-Cooper, 1983:236.

Not Terebratula wilmingtonensis Aldrich, 1907:9 [= Rhytisoria alabamensis Cooper, 1983:240].

This is an important species in the Tertiary (Eocene) of the eastern United States. It is noteworthy not only for the peculiarities of its loop, on which Cooper (1983) based the genus Plicatoria, but also for the remarkable variation of its specimens. Stenzel (1943, card 129) improperly put "Terebra- 


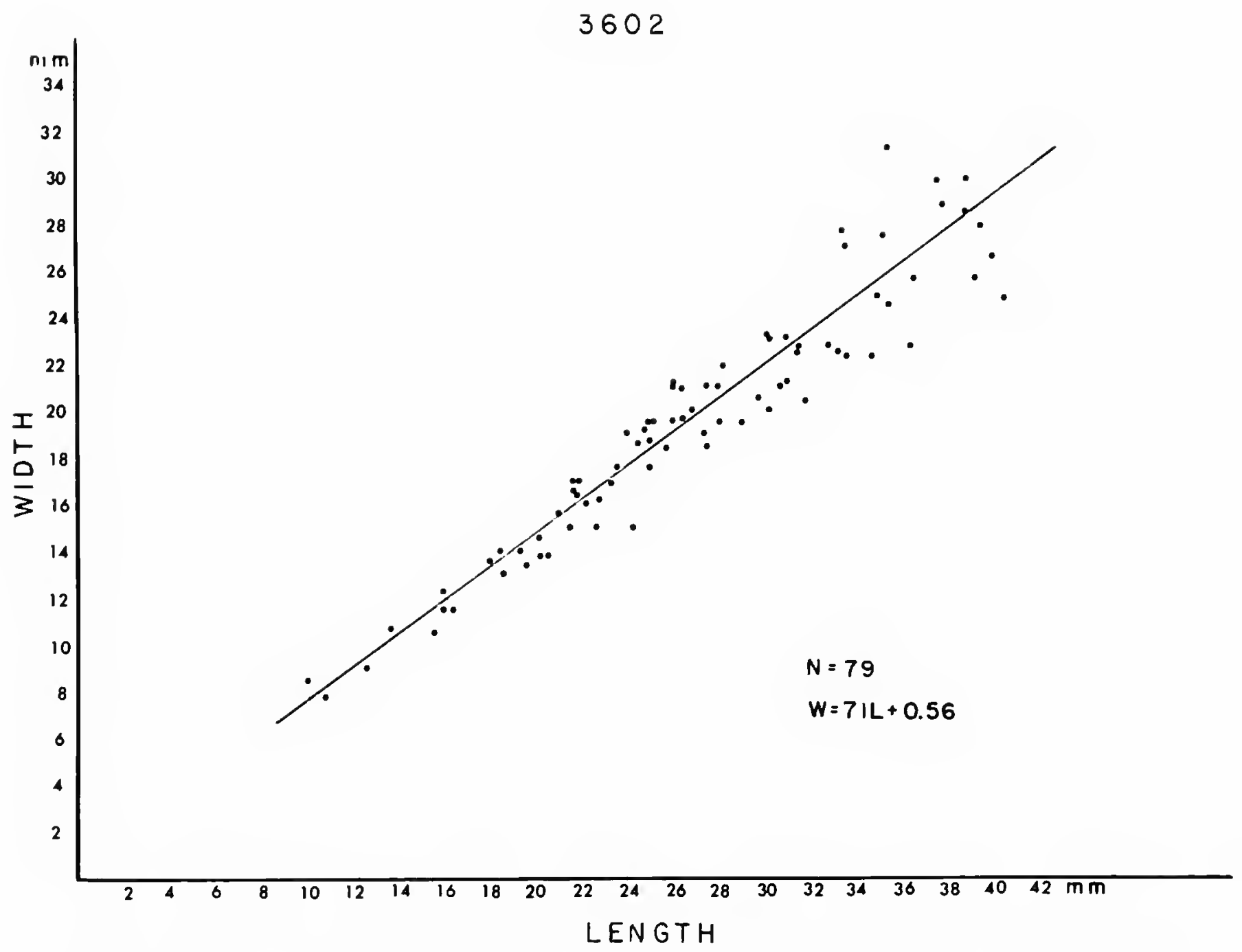

FIGURE 5.-Scattergram showing width/length relationship of 79 specimens of Plicatoria wilmingtonensis (Lyell and Sowerby) from Wilmington, USGS locality 3602 (North Carolina 1)

3602

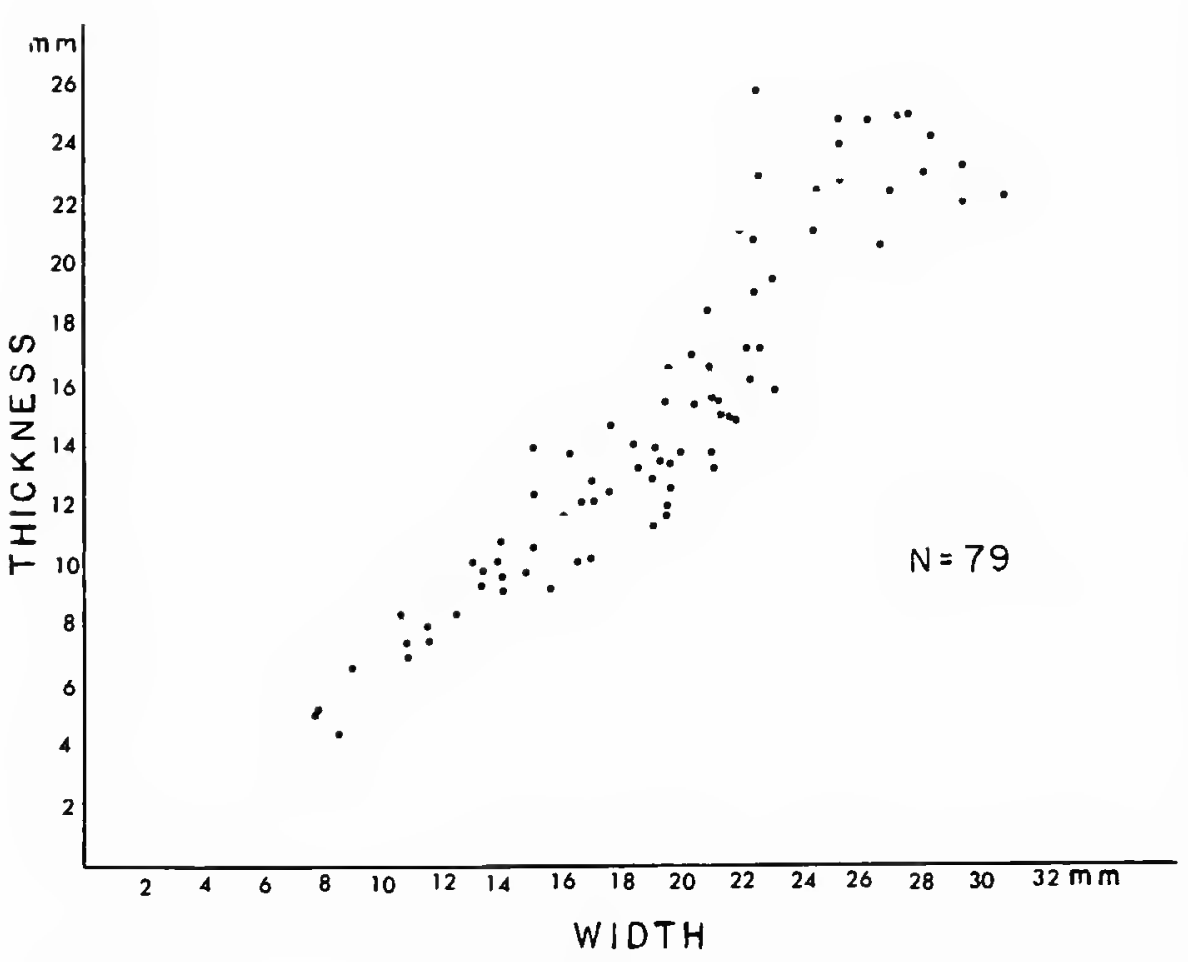

FIGURE 6.-Scattergram showing thickness/width relationship of 79 specimens of Plicatoria wilmingtonensis (Lyell and Sowerby) from Wilmington, USGS locality 3602 (North Carolina 1 ) tula" wilmingtonensis Lyell and Sowerby in synonymy with "Terebratula" canipes Ravenel (1844) an earlier named species. The Ravenel species has never been figured, but its description indicates a species unlike "T." wilmingtonensis. Moreover, Ravenel's species is said to have come from the Santee Formation of South Carolina (Stenzel, 1943, card 129). Stenzel selected specimens from the Castle Hayne Formation from Rocky Point, North Carolina, as "neotypes" of "T." canipes, the type of which is said to be lost. This naming of neotypes is an improper procedure because there can be only one neotype and the designated specimen must come from the type locality of "T." canipes, or close to it. Stenzel's selected specimens come from a different formation and different state than did Ravenel's "types." Stenzel's selection therefore cannot be accepted. Dall (1903:1537) regarded Ravenel's species as unrecognizable and placed the Castle Hayne specimens from Wilmington, North Carolina, in Lyell and Sowerby's (1845) species. Cooper (1983:241) rejected Stenzel's synonymy and followed Dall in recognizing Lyell and Sowerby's species, even though its type specimen is a noncostate young one.

Kellum (1926:7) recognized Terebratula wilmingtonesis Lyell and Sowerby in the Castle Hayne Formation of North Carolina and stated that "the species is remarkably variable in 


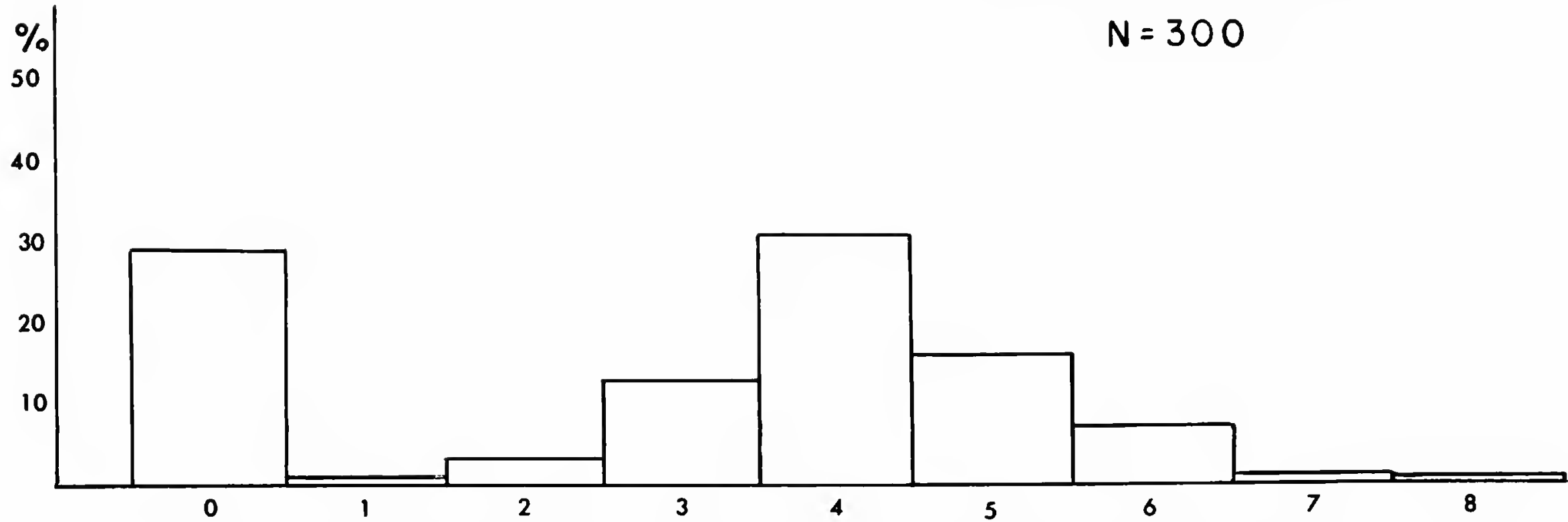

FIGURE 7.-Histogram showing frequency of numbers of costae on 300 specimens of Plicatoria wilmingtonensis (Lyell and Sowerby) from Wilmington (North Carolina 1). Specimens without costae mostly young.

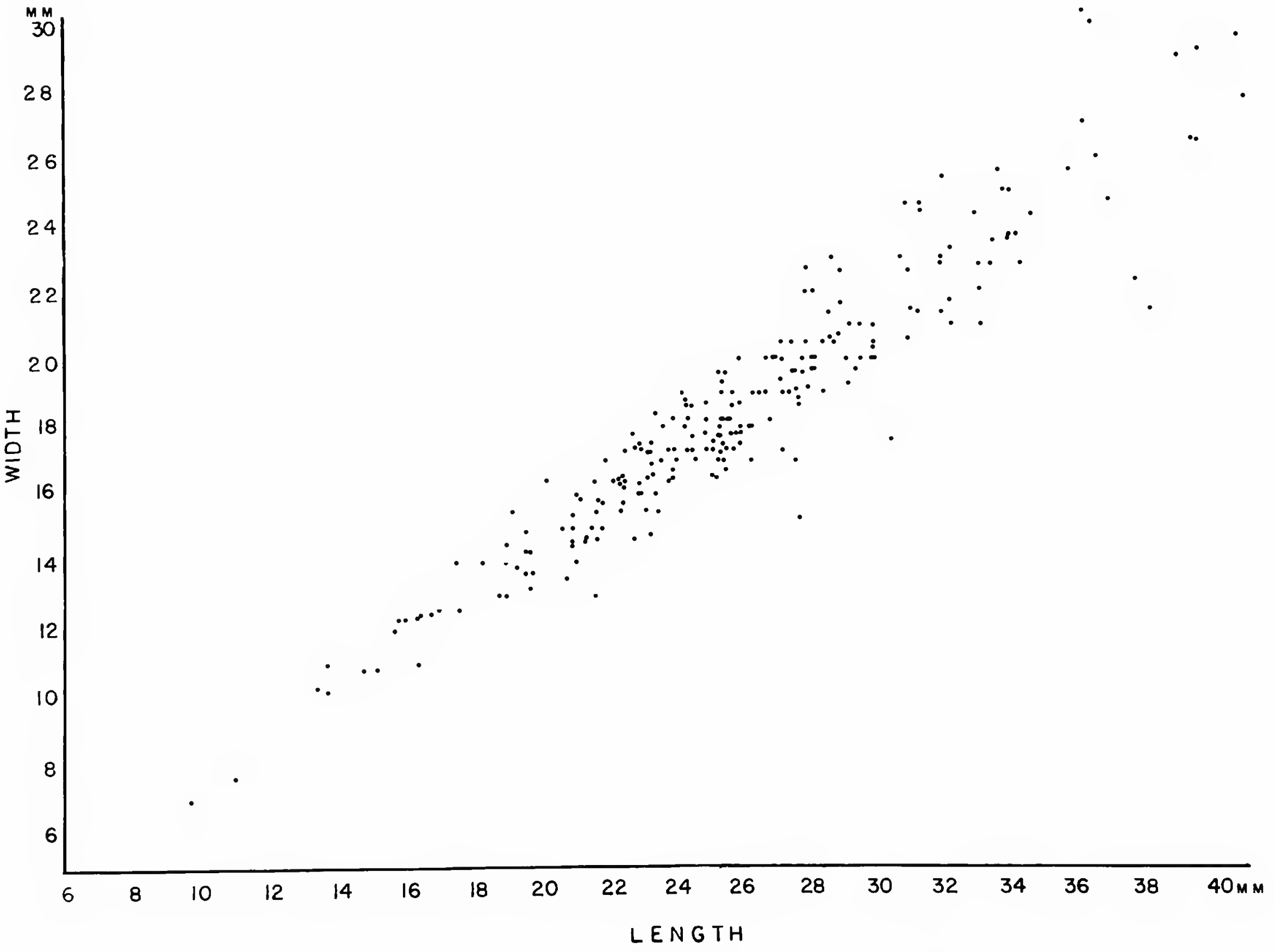

FIGURE 8.-Scattergram showing width/length relationship of 235 specimens of Plicatoria wilmingtonensis (Lyell and Sowerby) from Ideal Cement Company Quarry (North Carolina 2) 


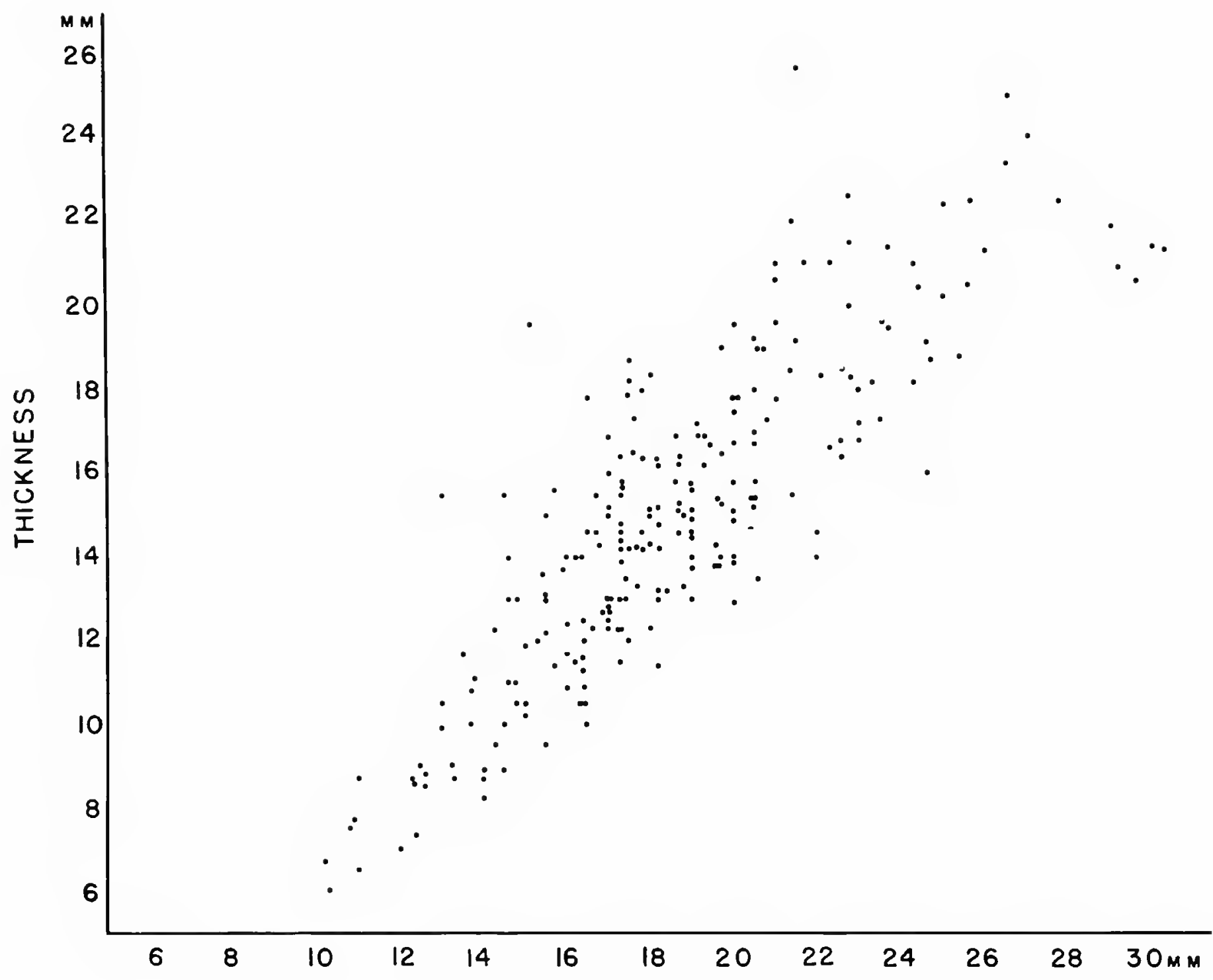

WIOTH

FIGURE 9.-Scattergram showing thickness/width relationship of 235 specimens of Plicatoria wilmingtonensis (Lyell and Sowerby) from Ideal Cement Company Quarry (North Carolina 2).

form, and variations of it have been described by several authors under different specific names[?]. A large number of specimens, however, show perfect gradations between the most widely varying forms."

The following remarks are based on collections from two localities: the quarry or quarries in the east side of Wilmington, and the Ideal Cement Company Quarry, northeast of Castle Hayne not far southeast of Wilmington (North Carolina localities 1 and 2).

The collection of Plicatoria wilmingtonensis from the city of Wilmington contains more than 400 specimens in several lots with separate United States Geological Survey locality numbers (see description of locality North Carolina 1). About 150 of these are juveniles, at any rate smooth, or showing only incipient stages of costation. Eleven of the collections are from North Carolina 1. All of the Wilmington lots were gathered early in this century by different collectors. Lots USGS 3602 and 3609 , both from City Rock Quarry, contain good samples of the species, including young and old specimens and have the appearance of random samples. The first was collected by
Dr. L.W. Stephenson and the second by Dr. T.W. Vaughan, both distinguished members of the United States Geological Survey. Collection 3602 consists of 103 specimens, 79 of which were measured and appear on the scattergram, and an additional 13 (USNM 549389a-m) that are illustrated (Plate 7) to show various adult expressions of the species.

Collection 3609 has 94 specimens and contains numerous young, noncostate forms, as well as a residue of imperfect, unmeasureable specimens. Dall (1903) recognized the great variation in this species when he placed very different forms together (USNM 138055, 549425-549429).

The collection from Ideal Cement Company Quarry (locality North Carolina 2) includes about 600 specimens of which 235 were measured for the scattergrams (Figures 8, 9). This collection was brought together by several collectors chief of whom was Peter J. Harmatuck who accounted for about two-thirds of the specimens. The Wilmington specimens differ from those from the Ideal Cement Company Quarry in having cream colored or light yellow shells while the others are grayish white. 


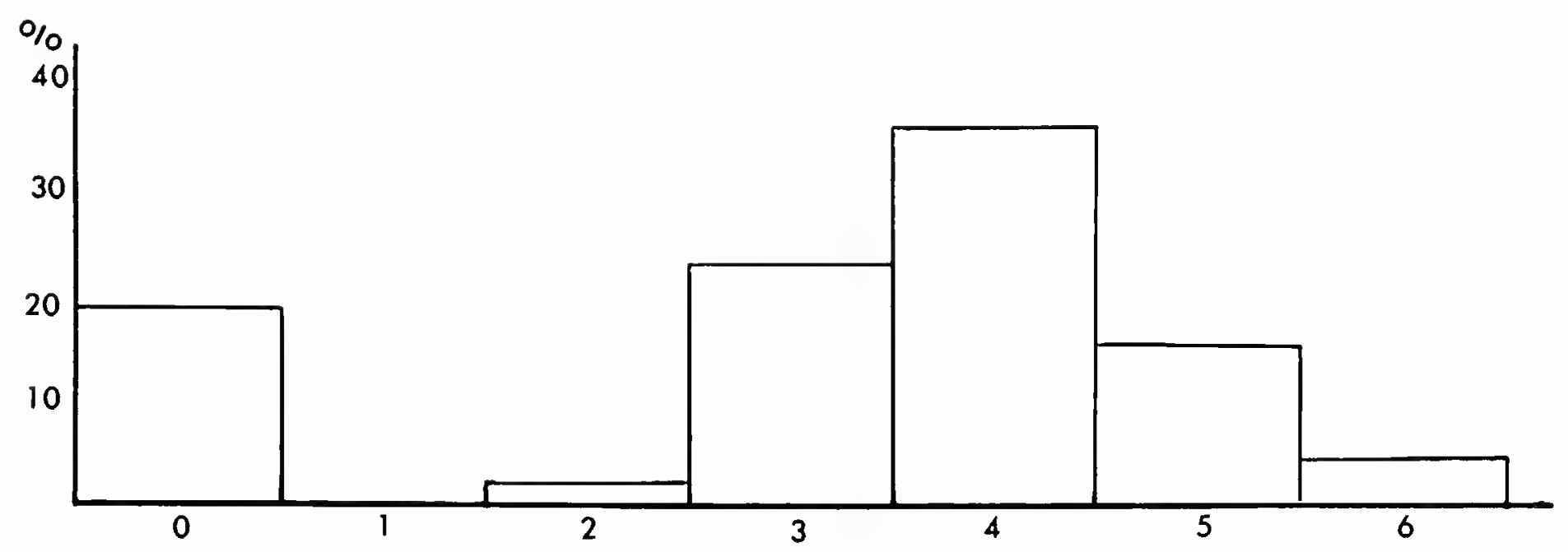

FIGURe 10. Histogram showing frequency of numbers of costae on 235 specimens of Plicatoria wilmingtonensis (Lyell and Sowerby) from Ideal Cement Company Quarry (North Carolina 2). Those without numbers are young, smooth shells.

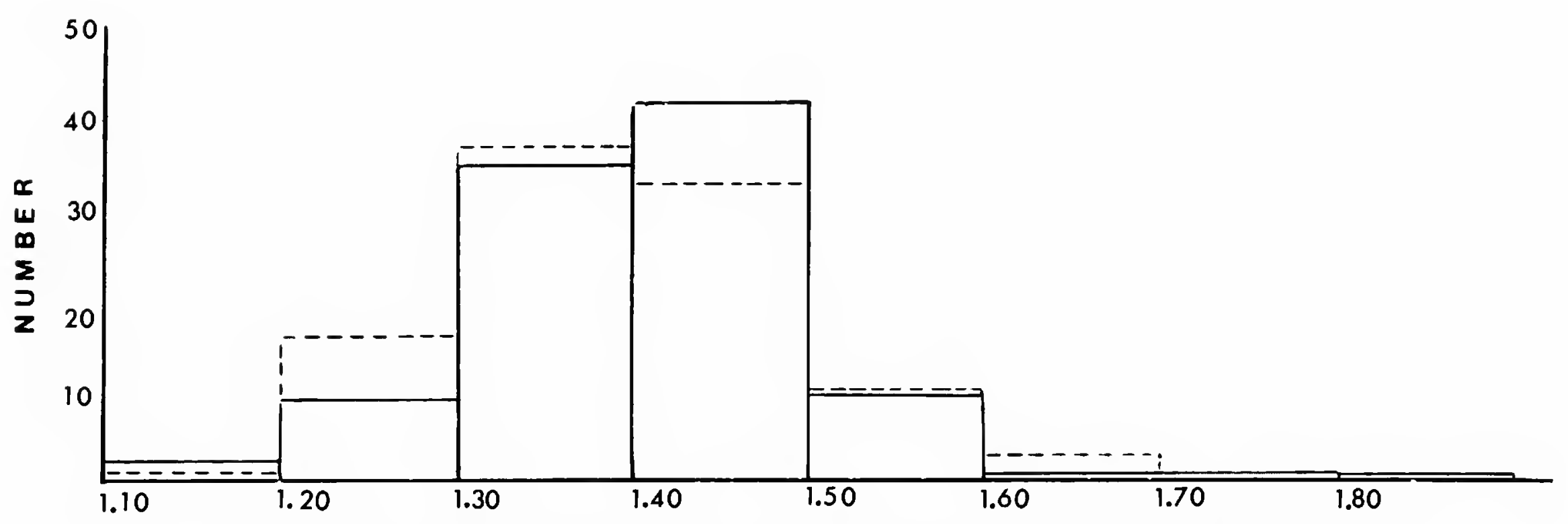

FIGURE 11.-Histogram showing frequency of width/length ratios of Plicatoria wilmingtonensis (Lyell and Sowerby) from Wilmington (North Carolina 1) and Ideal Cement Company Quarry (North Carolina 2). (Dotted line = Wilmington; solid line $=$ Ideal Cement Company Quarry.)

FOLDING AND COSTATION.-The young and smooth young adults are commonly rectimarginate, a condition that may exist into adulthood in a few specimens. A few very young specimens show incipient uniplication which is usually accompanied by costation. Uniplication starts at the anterior of the dorsal valve with the appearance of two costae that define a fold. A more or less prominent depression appears between the two costae on the dorsal valve. On the ventral valve the two dorsal costae are opposed by a low fold. Simultaneously, or shortly after the appearance of the initial costae defining the developing fold, one or more secondary costae appear in the depressed space between the initial two on the dorsal valve. These intercalated costae, which number from 1 to 5 , may be depressed between the initial 2 or rise above them to make a low fold between the 2 primary ribs. A similar arrangement may occur on the ventral valve. The costae on the ventral valve form a well-defined fold, which unites with the elevated costae of the dorsal valve and may produce a protuberance or nasute anterior. In some specimens, the costae of the ventral valve may be depressed to define a shallow sulcus.

In some specimens, especially depressed shallow ones, the initial lateral costae and the numerous intercalated ones are of about the same size and form a serrated margin (Plate 9: figures 20-22).

The initiation of costae is variable. The smallest specimen having costae (USNM 550810a) is $13.5 \mathrm{~mm}$ long and is marked by the two primary costae only. Specimens as long as $40 \mathrm{~mm}$ may be without costae (USNM 550868). Costation usually occupies one-half to one-third valve length, rarely as much as two-thirds valve length.

Other than the appearance of the initial two costae, there is no general rule governing the appearance of additional costae. In rare cases, the depression between the initial costae becomes a well-defined sulcus (USNM 549389h). Generally narrowly oval or subcylindrical specimens, when anteriorly costate, are more strongly nasute than wider oval forms (USNM 549389i).

Like the median part of the valves, the flanks vary from smooth to costate, often three, rarely as many as six costae. 
TABLE 2.-Distribution of morphologic types of Plicatoria wilmingtonensis (Lyell and Sowerby) in Wilmington localities and the Ideal Cement Company Quarry (Other = unclassified; numbers in parentheses indicate percentages).

\begin{tabular}{|c|c|c|c|c|c|c|}
\hline Locality & $\begin{array}{l}\text { Number of } \\
\text { specimens }\end{array}$ & Type A & Type B & Type C & $\begin{array}{l}\text { Smooth } \\
\text { (young) }\end{array}$ & Other \\
\hline New County Quarry & 50 & 22 & 11 & 5 & 12 & 0 \\
\hline Cemetery Quarry & 16 & 12 & 2 & 2 & 0 & 0 \\
\hline City Quarry & 35 & 22 & 3 & 3 & 6 & 1 \\
\hline Locality 3609 & 71 & 35 & 3 & 0 & 32 & 1 \\
\hline Locality 3602 & 79 & 37 & 13 & 4 & 24 & 1 \\
\hline \multicolumn{7}{|l|}{ Totals: } \\
\hline Wilmington area & $251(100)$ & $128(51)$ & $32(13)$ & $14(6)$ & $74(29)$ & $3(1)$ \\
\hline Ideal Cement Co. & $235(100)$ & $122(52)$ & $61(26)$ & 0 & $51(22)$ & 0 \\
\hline
\end{tabular}

A number of types can be recognized, two of which are fairly persistent (Table 2).

Type A: This commonest type is widely oval with maximum width anterior to midvalve and with acute apical angle (USNM 549389c), angular costae usually beginning near midvalve, nasute anterior and dorsal valve occasionally sulcate. Dall's specimen (USNM 549425)(1903, pl. 58: figs. 16, 17) is an example. A specimen of Type A was selected by Stenzel (1943, card 129) as one of the "neotypes" of Terebratula canipes Ravenel. The specimens may be large or small and the fold may have from 3 to seven costae.

Type B: This type is narrowly subcylindrical, sides gently convex and subparallel, the anterior strongly nasute. Costae variable in number. An example of type B is USNM 549389i and Dall's specimen USNM 549426 (1903, pl. 58: fig. 15).

Type C: This type is broadly and longitudinally oval with very compressed, narrowly lenticular profile. Costation is sparse; this rare type is suggestive of " $T$ " demissirostra Conrad in shape but not so thick.

Type D: One specimen (USNM 549389k) has two strong angular plications on the dorsal valve and three on the ventral valve. Very rare.

Type E: Several smooth, anteriorly wide specimens have a rectimarginate anterior commissure and only incipient folding (USNM 550868).

Some smooth specimens with uniplicate anterior commissure and narrow anterior are referred to Tanyoscapha glabra Cooper (1983). Dall's specimen USNM 549429 (1903, pl. 58: fig. 11) is an example. Dall's specimen USNM 549428 (1903, pl. 58: fig. 20) is an example of Tanyoscapha sigmanae Cooper (1983). The unusual wedge-shaped specimens USNM 138055 (Dall 1903, pl. 58: fig. 19) were named by Cooper (1983) as a separate genus, Embolosia.

VARIATION IN FORM.-Plicatoria wilmingtonensis varies in shape and costation. Specimens are usually elongate oval, tapering posteriorly to form an apical angle usually less than $80^{\circ}$. Maximum width is at or anterior to midvalve. They are biconvex, the valves subequal in depth, the ventral valve usually slightly deeper. The oval outline varies from rarely roundly oval to subcylindrical with the gently rounded sides almost parallel (type B). Occasional rare specimens are very strongly convex, subcylindrical, rectimarginate with costation in its incipient stage (type E). Widely oval forms with straight posteriorly tapering sides are the commonest form (type A).

Geological Occurrence.-Eocene (Castle Hayne Formation, Comfort Member).

Localmties.-North Carolina 1-10.

TYPES.-Hypotypes: USNM 65142a; 549389a-n; 549425$549427 ; 549429 ; 549489 ; 550810 \mathrm{a} ; 550811-550813$; 550865a; 550866-550870, 550873-550879, 550880; 550894a; 550914ac; 551494a; 551495a; 551496a; 551497a; 551499; 551500 551502 ; 551524; 551525. Measured hypotypes: 549389-(179); 551494-(1-90); 551495-(1-70); 551496-(1-75).

LIVING HaBrTs.- It is likely that Plicatoria of the Eocene lived in grape-like clusters or bunches like Liothyrella notorcadensis (Jackson) from Arthur Harbor, Antarctica (Plate 4: figure 45). Specimens crowded or squeezed against their neighbors in a cluster tend to narrow form or stunted adults. This might account for the numerous small, strongly costate specimens which were unable to find room enough to attain normal size and shape as they grew thus stunted to adulthood.

REMARKS.-Conrad's plate 3 exhibits three views of a brachiopod identified as Terebratula demissirostra, figure 1, consisting of dorsal and side views of a large specimen and another figure 1 (probably 7) of a smaller specimen in ventral view. No enlargement is given for the figures (reproduced herein as Plate 9: figures 10 and 11); one assumes they are at natural size. The specimens are from Wilmington, North Carolina. The large specimen, according to Conrad's figures measures (in $\mathrm{mm}$ ): length 49.0, width 30.0 , and thickness 29; $\mathrm{L} / \mathrm{W}=1.63$. It is posteriorly attenuated and has its greatest width anterior to midvalve. It is said to have 5 plications, the lateral ones the widest. In outline, this specimen is like some of Type A in which costation is retarded to late adulthood (Plate 9: figure 15), but its thickness and length are greater than those of any specimens of this type in the collection. It is also larger than Ravenel's specimen of " $T$." canipes, which also exceeds in width any specimens from Wilmington. 
Conrad figures a small specimen on his plate 3 , numbered one (probably 7) but does not refer to it and there is no legend for plate 3 in Appendix A. This is of a specimen seen from the ventral side, measuring $25 \mathrm{~mm}$ long by $19 \mathrm{~mm}$ wide $(\mathrm{L} / \mathrm{W}=$ 1.32) and having 2 incipient anterior costae on the left side. This suggests a more normal specimen of Plicatoria wilmingtonensis of type A, but there are no data with it.

Inasmuch as these specimens of Conrad's conform to the broad concept of Plicatoria wilmingtonensis developed here, it seems best to place Conrad's species in the synonymy of $P$. wilmingtonensis, his specimen representing an unusually large example.

A cluster of specimens of the modern, large brachiopod Liothyrella notorcadensis (Jackson, 1912) (Plate 4: figure 45), so similar to Plicatoria, is illustrated to give an idea of the possible life habit of Plicatoria. Such clusters with large and small specimens crowded together did not permit freedom of growth to all individuals. Some impinged against their fellows in such a way that growth might be limited on one side, or both sides, with resulting malformation or stunting. It is possible that specimens in such a situation developed full adult characters without being able to expand to normal size. The development of adult characters in stunted specimens is a phenomenon often seen in fossil brachiopods. Some of the small specimens of Plicatoria that have adult costation are possible examples (Plate 9: figures 24-27).

LoCALITY.-Antarctica 1.

TYPES.-Hypotype USNM 550885.

\section{Plicatoria parva, new species}

Plate 3: Figures 30-36

Diagnosis.-Small rectimarginate Plicatoria with incipient costation.

DESCRIPTION.--Small, elongate oval, maximum width anterior to midvalve, anterior margin rounded; posterolateral margins forming angle of $75^{\circ}-77^{\circ}$; valves subequally convex; ventral valve more convex than dorsal one. Lateral commissure straight; anterior commissure rectimarginate to development of slight sulcation. Beak long, suberect. Foramen large, round, submesothyridid. Symphytium visible. Smooth except for occasional growth varices and incipient lateral costae.

Ventral valve moderately convex in lateral view, moderately and roundly domed in anterior profile. Umbonal region swollen, swelling continued anteriorly to midvalve, flattening anteriorly. Flanks rounded.

Dorsal valve flatly convex laterally, broadly and gently domed in anterior view. Umbonal and median regions moderately swollen; anterior less so. Flanks rounded, steep. Holotype with narrow sulcus and incipient lateral costae.

Dorsal valve with long loop occupying half dorsal valve length and one quarter of its width. Outer hinge plates long, deeply concave; crural processes at two-thirds loop length, needle sharp; transverse band broad, narrowly arched; terminal points short. Cardinal process large, semielliptical.
MEASUREMENTs.-All measurements are in millimeters, except apical angles, which are in degrees; questionmark indicates that thickness could not be measured.

$\begin{array}{lccccc}\text { USNM } & \text { Length } & \begin{array}{c}\text { Dorsal } \\ \text { valve } \\ \text { length }\end{array} & \text { Width } & \begin{array}{c}\text { Thick- } \\ \text { ness }\end{array} & \begin{array}{c}\text { Apical } \\ \text { angle }\end{array} \\ \text { 551529a } & 17.3 & 15.0 & 12.2 & ? & 77 \\ 551529 \mathrm{~b} & 15.8 & 14.0 & 11.5 & 7.5 & 75\end{array}$

Geological Occurrence.-Eocene (Cross Member of the Santee Formation).

LoCALITY.-South Carolina 3.

TYPES.-Holotype: USNM 551529a; paratype: USNM $551529 \mathrm{~b}$.

Discussion.-This species is assigned to Plicatoria because of its long loop, forward position of the crural processes, extremely long, deep outer hinge plates and incipient folding. The anterior of the left side of the loop has been damaged.

This species is the smallest described species of Plicatoria.

\section{Plicatoria ventricosa, new species}

Plate 6: FiguRES 37-40

DiaGNOsIs.-Laterally compressed, strongly convex Plicatoria.

DESCRIPTION.-Medium size, narrowly elongate, elliptical in outline; sides gently rounded; anterior margin narrowly rounded; subequally biconvex, ventral valve slightly more convex than ventral one. Apical angle $46^{\circ}-69^{\circ}$. Lateral commissure concave toward ventral side; anterior commissure rectimarginate to uniplicate. Beak protuberant, suberect; foramen large, round, permesothyridid. Symphytium visible. Surface smooth except for incipient costation at anterior in old specimens.

Ventral valve strongly convex in lateral view, narrowly domed with steep, straight sides. Umbonal region swollen, swelling continuing to anterior margin. Ventral interior with short sessile pedicle collar. Muscle scars not seen.

Dorsal valve with strongly convex lateral profile and narrowly domed anterior view. Umbonal region swollen, swelling continued to anterior margin. Sides nearly straight and steep. Dorsal valve interior with flat semielliptical cardinal process; loop length one-third valve length; outer hinge plates long; crural processes at about 0.7 of loop length. Transverse band broad, narrowly folded.

MEASUREMENTS.-All measurements are in millimeters, exr,ept apical angles, which are in degrees.

$\begin{array}{lccccc}\text { USNM } & \text { Length } & \begin{array}{c}\text { Dorsal } \\ \text { valve } \\ \text { length }\end{array} & \text { Width } & \begin{array}{c}\text { Thick- } \\ \text { ness }\end{array} & \begin{array}{c}\text { Apical } \\ \text { angle }\end{array} \\ \text { 551498a } & 29.5 & 26.0 & 18.0 & 20.3 & 68 \\ 551498 \mathrm{~b} & 32.0 & 27.7 & 21.0 & 22.3 & 68 \\ 551498 \mathrm{c} & 25.2 & 22.0 & 16.5 & 18.0 & 68 \\ 551498 \mathrm{~d} & 32.2 & 27.5 & 18.2 & 21.0 & 46 \\ 551498 \mathrm{e} & 24.0 & 21.4 & 16.0 & 15.6 & 69\end{array}$


Geological Occurrence.-Eocene (Castle Hayne Formation, Comfort Member).

LocalrTY.-North Carolina 2.

TYPES.-Holotype: USNM 551498a; paratypes: USNM 551498b-g.

Discussion.-This species differs from all others in the great thickness and convexity of the valves, which produce a laterally compressed rather elliptical outline when viewed from the dorsal side. Although the holotype shows only traces of costation, specimens USNM 551498b, d, and g, are costate in the anterior third of the median part of the shell; the flanks are not costate. This is a rare species.

\section{Genus Rhytisoria Cooper, 1983}

\section{Rhytisoria alabamensis Cooper, 1983}

Plate 3: Fgures 42-46

Terebratula wilmingtonensis.-Aldrich, 1907:9 [not Terebratula wilmingtonensis Lyell and Sowerby, 1845].

Rhytisoria alabamensis Cooper, 1983:240, pl. 53: figs. 1-7.

This brachiopod, which comes from the Paleocene, was identified by Aldrich (1907:9) who stated that "all the different forms of Terebratula wilmingtonensis mentioned and figured by Prof. Dall [1903] in Vol. 3, of Wagner Free Inst. of Science, p. 1537, pl. 58, figures 14-20, are found here [Brundidge Depot, Alabama]." Specimens from Brundidge Depot, however, are folded differently and have a completely different loop from that of Oleneothyris and that of Plicatoria (e.g., "T." wilmingtonensis).

According to Stenzel (1943, card 133), "Aldrich's conclusions concerning the Jackson age of this fossil [Terebratulina brundidgensis Aldrich] and his identification of Terebratula wilmingtonensis seem to be erroneous. The geologic map of Alabama (1926) shows only Nanafalia formation at Brundidge and the Jackson is too far away to produce outliers at this place." This is a lesson in misconception of geologic age that can arise from species misidentification.

Geologic OcCURRENCE.-Paleocene (Wilcox Group, unnamed limestone below the Nanafalia Formation).

LOCALITY.-Alabama 1.

TYPES.-Holotype: USNM 549392a; paratypes: USNM 549392b-g.

\section{Superfamily Terebratellacea King, 1850}

Unlike the Tertiary of the Southern Hemisphere, which is rich in terebratellids, only two are known from the Tertiary of the eastern United States: Argyrotheca and Platidia. The former is common in the Mediterranean and Caribbean seas but rare elsewhere. Platidia is rare but widely distributed in modern seas. Both are rare in the Pacific. Platidia occurs in the Pliocene and Pleistocene of the West Coast (reported as
Morrisia by Hertlein and Grant, 1944). It is rarely found in the Eocene of the East Coast.

Argyrotheca is abundant in the Tertiary of the Caribbean region, occurring in a variety of species (Cooper, 1977, 1979). It was found by Cooper (1971) in Eocene deposits on the Island of Eua, Tonga Group, central Pacific Ocean. It occurs rarely in the Miocene of New Zealand.

In addition to the species described below, Stenzel (1943) and others described Tertiary species of Argyrotheca, as follows. Paleocene: A. dalli Aldrich, 1911; A. hatchetigbeensis Stenzel, 1940; A. plicatilis Clark, 1895; A. powersi Gardner, 1925; A. saltmountainensis Toulmin, 1940. Eocene: $A$. akymatophora Stenzel, 1940.

Clark and Martin (1901) described Platidia marylandica and Toulmin (1940) described Platidia? sp. from the Salt Mountain Limestone of Alabama.

Genus Argyrotheca Dall, 1900

Argyrotheca beecheri (Clark, 1895)

Plate 1: Figures 5-8

Cistella beecheri Clark, 1895:3, figs. $C^{1} C^{2}$.-Weller, 1907:361, pl. 27: figs. 14-17.

Argyrotheca beecheri (Clark).-Stenzel, 1943, card 140.

This is a small Argyrotheca strongly resembling $A$. quadrata, new species. It differs in having narrowly convex costae with wide interspaces and less costae on a side, with fewer intercalations. The figured types show no intercalations although Clark mentions, and Weller (1907, pl. 27: figs. 14, 15) figures, two specimens with a median costa inserted at the anterior of the wide sulcus. Of 38 specimens in the USNM collections only one shows a costa in the sulcus. Argyrotheca quadrata usually has an intercalated costa in its sulcus but also short intercalations between the lateral costae in many specimens.

Geological Occurrence.-Paleocene (Vincentown Formation).

LOCALITY.-New Jersey 1.

TYPES.-Hypotype: USNM 551523a.

\section{Argyrotheca laevis, new species}

Plate 9: Figures 45-50

DIAGNosis.-Small, smooth Argyrotheca.

DESCRIPTION.-Small, subpentagonal in outline, length and width about equal; hinge straight, narrower than maximum width which is slightly anterior to midvalve. Sides rounded. Beak moderately extended. Cardinal extremities obtuse. Valves subequal in depth. Anterior commissure rectimarginate. Coarsely punctate. Surface smooth.

Ventral valve broadly convex in lateral profile. Beak forming angle of $95^{\circ}-96^{\circ}$. Interareas narrow; delthyrium wide, margined by low, oblique lateral plates. Interior with long 
excavated pedicle collar. Median septum long, occupying 7/8 shell length; crest at about $3 / 4$ valve length from beak. Crest of septum with oval pit.

Dorsal valve broadly and gently convex in side and anterior views. Notothyrial chamber short, narrow, occupied by low myophragm. Septum high, long, reaching anterior margin with angular crest at about midvalve. Loop not preserved. Adductor scars elongate, teardrop shape.

MEASUREMENTS.-All measurements are in millimeters, except apical angles, which are in degrees; questionmark indicates that thickness could not be measured.

$\begin{array}{lcccccc}\text { USNM } & \text { Length } & \begin{array}{c}\text { Dorsal } \\ \text { valve } \\ \text { length }\end{array} & \begin{array}{c}\text { Hinge } \\ \text { width }\end{array} & \begin{array}{c}\text { Maximum } \\ \text { width }\end{array} & \begin{array}{c}\text { Thick- } \\ \text { ness }\end{array} & \begin{array}{c}\text { Apical } \\ \text { angle }\end{array} \\ & & & & & & \\ 551506 \mathrm{a} & 2.2 & 1.7 & 1.7 & 2.2 & 1.0 & 95 \\ 551506 \mathrm{~b} & 2.5 & 2.0 & 2.2 & 2.5 & ? & 96\end{array}$

Geological OccurRence.-Oligocene (Ashley Member of Cooper Formation).

LOCALITY.-South Carolina 5.

TYPEs.-Holotype: 551506a; paratypes: 551506b, c.

Discussion.-Two smooth argyrothecas are known from Eocene rocks: A. akymatophora Stenzel (1940) and $A$. saltmountainensis Toulmin (1940). The first is a much larger species than $A$. laevis, new species, nearly twice its size and differently shaped. The second is about the same size as $A$. laevis but is ambiguous in having shells grading from smooth to poorly costate. Argyrotheca saltmountainensis is from Lower Eocene strata and is differently shaped, being quadrate with the hinge about equal to its maximum width.

\section{Argyrotheca macneili, new species}

Plate 4: Figures 1-23

Diagnosis.-Small, wide Argyrotheca with about 10 distant costae.

DESCRPTION.-Very small, rectangular to semielliptical; hinge wider than width at midvalve; cardinal extremities usually acute. Anterior margin broadly rounded; anterior commissure varying from rectimarginate to broadly and gently sulcate. Interareas well developed, apsacline to catacline. Foramen large and irregular; beak distorted; deltidial plates absent or rudimentary. Surface distantly costate, costae narrow, separated by spaces wider than costae; costae opposite, numbering about 10 ; anterior margin gently scalloped.

Ventral valve hemipyramidal in side view with moderate convexity; anterior profile subtriangular with apex broadly to somewhat narrowly rounded. Lateral regions flattened, forming long steep slopes.

Dorsal valve variable in lateral profile from slightly concave to gently convex. Anterior profile nearly flat, slightly convex or gently concave, especially in the midregion corresponding to sulcus. Cardinal extremities flattened; sulcus shallow, widening anteriorly, not strongly impressed and usually occupied by one costa that does not reach the apex; median costa matching one in median flattened part of ventral valve.

Ventral valve interior with variable apical plate, short in some, greatly elongated in others; apical plate supported by strong median septum extending to slightly beyond midvalve. Teeth flattened and wide.

Dorsal valve interior with narrow delthyrial platform, wide socket ridges bounding slit-like sockets. Median septum strong with apex anterior of midvalve and with concave nonserrate anterior margin.

MEASUREMENTS._-All measurements are in millimeters.

$\begin{array}{lcccc}\text { USNM } & \text { Length } & \begin{array}{c}\text { Dorsal } \\ \text { valve } \\ \text { length }\end{array} & \begin{array}{c}\text { Hinge } \\ \text { width }\end{array} & \begin{array}{r}\text { Thick- } \\ \text { ness }\end{array} \\ 550458 \mathrm{a} & 2.0 & 1.8 & 3.0 & 1.7 \\ 550458 \mathrm{~b} & 2.1 & 1.5 & 3.0 & 1.6 \\ 550458 \mathrm{c} & 2.0 & 1.6 & 3.0 & 1.6 \\ 550458 \mathrm{~d} & 1.8 & 1.7 & 2.8 & 1.5\end{array}$

Geologic Occurrence.-Paleocene (Midway Group, Fort Gaines Formation).

LocalrTy.-Alabama 3.

TYPES.-Holotype: USNM 550458a; paratypes: 550458b-j.

Discussion.-The collection of this species consists of several hundred specimens, all fairly uniform in size. The species is small and therefore comparable only to other small species. It is of about the same size as the variable Argyrotheca saltmountainensis Toulmin (1940) from the Salt Mountain Formation of Alabama. The Salt Mountain species is more square than $A$. macneili.

Argyrotheca beecheri (Clark) is another small species, squarish in outline and strongly costate, three thick costae on a side and a thick one in the middle, quite unlike $A$. macneili. The Eocene of Cuba has a number of undescribed small species of Argyrotheca, but none is as small as, or marked like, the Alabama species.

Argyrotheca hatchetigbeensis Stenzel, 1940, is a small Eocene species suggestive of $A$. macneili but is larger, proportionately wider, and with more numerous, more crowded costae than A. macneili. Shell proportions, distant costae, and irregularity of the interarea distinguish $A$. macneili from $A$. quadrata, new species.

It is interesting to note that $A$. macneili occurs with two other brachiopods, both of them very small, but adults nevertheless. These are new species of Lacazella and Thecidellina, both of which occur in the Caribbean with numerous species of Argyrotheca.

\section{Argyrotheca quadrata, new species}

Plate 2: figures 1-8; Plate 4: figures 40-44; Plate 5: gigures 12-25; Plate 9: Figures 41-44

Diagnosis.-Quadrate Argyrotheca with length and width nearly equal, and with strong rounded costae. 
DESCRIPTION.-Small, quadrate, sides gently rounded; anterior margin strongly rounded; hinge slightly narrower or equal to midwidth. Cardinal extremities slightly obtuse. Interarea fairly long, strongly apsacline. Anterior commissure faintly sulcate. Margins strongly scalloped because of opposite costae; adult with 6 primary strongly rounded costae and short intercalated costae to a maximum of 13 costae.

Ventral valve moderately convex in lateral profile with maximum curvature at midvalve; anterior profile moderately convex; ears not prominent. Median 2 costae forming shallow sulcus that bears 1 to 3 intercalated costae, median one strong, others short. Lateral slopes steep. Interior with thick, long pedicle collar or apical plate; delthyrium wide; median septum low, extending beyond midvalve and bearing 3 anterior pits.

Dorsal valve slightly less deep than ventral one, fairly evenly and gently convex in side view. Sulcus shallow, bounded by 2 median primary costae, a strong intercalated median costa and often 2 lateral marginal ones. Interior with strong socket ridges defining narrow sockets; median septum extending to anterior margin, rising to sharp crest at about midvalve, then tapering to margin. Anterior edge of septum marked by strong serrations.

MEASUREMENTS.-All measurements are in millimeters.

$\begin{array}{lccccc}\text { USNM } & \text { Length } & \begin{array}{c}\text { Dorsal } \\ \text { valve } \\ \text { length }\end{array} & \begin{array}{c}\text { Hinge } \\ \text { width }\end{array} & \begin{array}{c}\text { Maximum } \\ \text { widlh }\end{array} & \begin{array}{c}\text { Thick- } \\ \text { ness }\end{array} \\ 550881 \mathrm{a} & 2.0 & 1.8 & 2.0 & 2.1 & 1.3 \\ 550881 \mathrm{~b} & 1.8 & 1.6 & 1.7 & 2.0 & 1.0 \\ 551507 \mathrm{a} & 1.8 & 1.5 & 1.45 & 1.75 & 0.9 \\ 551507 \mathrm{~b} & 1.7 & 1.4 & 1.6 & 1.7 & 0.8\end{array}$

Geological Occurrence.-Eocene (Castle Hayne Formation; Santee Formation; Cross Member of the Santee Formation).

LoCALITIES._North Carolina 1, 3; South Carolina 2, 3.

TYPES.-Holotype: USNM 550881b; paratypes: USNM 550881a, c, d; hypotypes: USNM 551007a, b; 551504a-d, $551508 \mathrm{a}-\mathrm{e}$.

Discussion.-This species need be compared only with ones of similar size: A. beecheri (Clark), A. macneili, new species, and $A$. saltmountainensis Toulmin. The first is slightly larger than $A$. quadrata with less numerous costae that are narrowly convex, a more prominent fold and sulcus, and only one or no costa intercalated in the sulcus.

The or namentation and shape of A. quadrata and A. macneili are so different that further comparison is unnecessary. Argyrotheca saltmountainensis Toulmin (1940) is similar in size and shape to that of A. quadrata, but Toulmin's (1940:231) species is smooth or only faintly costate. One of Toulmin's paratypes (Princeton University catalog number 50754) is fairly strongly costate and has the appearance of $A$. quadrata, but Toulmin's Alabama specimen has fairly even costae, all of which appear to be primary without the anterior intercala- tions characteristic of $A$. quadrata. Furthermore, there is no evidence of a sulcus like that of the North Carolina species.

\section{Argyrotheca quadrata transversa, new subspecies}

Plate 4: FGURES 46-52

Diagnosis.-Similar to A. quadrata but with wide hinge.

DESCRIPTION.-Small, wider than long; subrectangular; hinge forming widest part; cardinal extremities angular; slightly extended. Sides slightly oblique; anterior broadly rounded; anterior commissure rectimarginate. Surface marked by 10 narrowly rounded costae. Median sulcus narrow, occupied by a single costa longer on the ventral side than on the dorsal side. Five costae on a side.

Ventral valve more strongly convex in anterior view than the dorsal valve; flatly convex in side view. Interareas fairly broad with oblique plates on the delthyrial margin. Delthyrium wide, revealing prominent pedicle collar (Plate 4: figure 50).

Dorsal valve gently convex in lateral view, broadly and fairly strongly convex in anterior view.

MEASUREMENTS.-All measurements are in millimeters.

$\begin{array}{lccccc}\text { USNM } & \text { Length } & \begin{array}{c}\text { Dorsal } \\ \text { valve } \\ \text { length }\end{array} & \begin{array}{c}\text { Hinge } \\ \text { width }\end{array} & \begin{array}{c}\text { Maximum } \\ \text { width }\end{array} & \begin{array}{c}\text { Thick- } \\ \text { ness }\end{array} \\ 551505 \mathrm{a} & 2.0 & 1.6 & 2.65 & 2.5 & 1.6 \\ 551505 \mathrm{~b} & 1.8 & 1.6 & 2.4 & 2.0 & 1.2\end{array}$

Geological OccurRence.-Eocene (Castle Hayne Formation).

LocaliTY.--North Carolina 3.

TYPES.-Holotype: USNM 551505a; paratypes: 551505b, c.

Discussion.-This subspecies resembles $A$. quadrata, new species, in its costation and the intercalation of a median costa in the sulcus, but it is more transverse in outline.

\section{Argyrotheca semicostata, new species}

$$
\text { Plate 1: figures 1-4 }
$$

DiaGNosis.-Argyrotheca with posterior two-thirds costate, anterior one-third smooth.

DESCRIPTION.-Small, subrectangular, anterior margin broadly rounded, sides somewhat narrowly rounded; hinge straight, narrower than maximum shell width at midvalve. Valves unequally convex, ventral valve strongly convex, dorsal valve less so. Beak protuberant, interareas very narrow. Delthyrium wide, margined by oblique plates. Surface semicostate, anterior smooth, posterior two-thirds marked by 6 , indistinct, wide costae. Punctation coarse. Concentric growth varices prominent anteriorly.

Ventral valve strongly convex in side and anterior views; umbonal region costate, marked by narrow median sulcus disappearing at midvalve.

Dorsal valve moderately convex in lateral view, most convex 
just anterior to midvalve; broadly domed with slight median carination in anterior view. Umbo marked by a wide trough between costae, disappearing anteriorly and corresponding to sulcus on ventral valve.

MEASUREMENTS (mm).-USNM 551503: length 2.6; dorsal valve length 2.0; hinge width 2.6; midwidth 2.9; thickness 1.5 ; apical angle $108^{\circ}$.

Geological OccurRence.-Eocene (Castle Hayne Formation).

LOCALITY.-North Carolina 3.

TYPES.-Holotype: USNM 551503.

Discussion.-This species, with its peculiar ornament is unlike any other described herein.

\section{Superfamily Thecmeacea Gray, 1840}

Only four genera of Thecideacea are known in the Tertiary: Lacazella, Thecidellina, Bifolium, and Glazewskia. The last two became extinct after the Tertiary; the other two are common in the Caribbean and rare in the modern Indian Ocean. Lacazella is common in the Mediterranean but not yet known in the modern Pacific. Thecidellina occurs in the Pacific and Indian oceans. Both genera are commonly found adhering to corallines, usually in fairly shallow water. One species is known from 300 meters. Lacazella is reported here for the first time in the Tertiary of the United States.

Thecidellina occurs in the Eocene of the Island of Eua in the Tonga Group, central Pacific (Cooper, 1971). Lacazella and Thecide!lina occur in early Miocene in Java and in Pleistocene deposits on Santo Island, New Hebrides. Although Lacazella is known as a fossil in the Pacific Tertiary, it is not now known from the modern Pacific but may be expected there.

Gregorio (1890) described a single valve as Thecidea? sp. (= Thecidea claibornensis). The description and figures (see Stenzel, 1943, card 123) strongly suggest the posterior part of a thick-shelled terebratulid with strongly punctate shell. No thecideid is known with punctae as depicted by de Gregorio. Furthermore, the interior with its deep median "sulcus" (deeply inset ventral muscle impression) is unlike the interior of any known thecideid, which usually has a hemispondylium. The specimen is a terebratulid of unknown affinities. It is said to come from "Presumably Gosport sand, Claiborne Group, middle Eocene." "Presumably Claiborne Bluff on the left bank of the Alabama River, Monroe County, Alabama" (both quotes from Stenzel, 1943, card 123).

\section{Genus Lacazella Munier-Chalmas, 1881}

\section{Lacazella nana, new species}

Plate 4: Figures 24-30

DiaGnosis.-Very small Lacazella.

DESCRIPTON.-Minute, varying from longer than wide to length and width nearly equal; subtriangular to pentagonal. Beak variable, acute to truncated; sides rounded, anterior margin straight or slightly emarginate. Cicatrix usually small. Interarea occupying about one-third shell length. Interarea marked by a fairly wide, triangular elevation (pseudodeltidium?). Surface marked by growth lines and interrupted undulations.

Ventral valve moderately deep, with trapezoidal profile; lateral slopes steep and rounded. Interior with strong teeth, hemispondylium not visible.

Dorsal valve lid-like, gently convex in both profiles. Interior with narrow ascending apparatus terminating at midvalve.

MEASUREMENTS.-All measurements are in millimeters; questionmark indicates that thickness could not be measured.

$\begin{array}{lcccc}\text { USNM } & \text { Length } & \begin{array}{c}\text { Dorsal } \\ \text { valve } \\ \text { length }\end{array} & \text { Width } & \begin{array}{c}\text { Thick- } \\ \text { ness }\end{array} \\ \text { 549362a } & 2.0 & 1.3 & 1.9 & 1.2 \\ 549362 \mathrm{~b} & 1.9 & 1.2 & 1.7 & ?\end{array}$

Geological OccurRence.-Paleocene (Clayton Formation).

LocalTTY.-Alabama 4.

TYPES.-Holotype: USNM 549362a; paratype: USNM $549362 \mathrm{~b}-\mathrm{e}$.

Discussion._Lacazella has not been reported hitherto in the American Tertiary. The collection includes only 15 specimens, mostly dorsal valves. These are similar to Thecidellina alabamensis, new species, with which they occur but are readily separated by the convex pseudodeltidium(?) on the interarea of the ventral valve and the open ascending apparatus. Lacazella nana is unlike any other described species in its minute size. Like Thecidellina, Lacazella is a shallow water form attached to corallines and shells.

\section{Genus Thecidellina Thomson, 1915}

Thecidellina alabamensis, new species

Plate 4: Figures 31-39

Diagnosis.-Minute Thecidellina with large cicatrix.

DESCRIPTION.-Minute, subpentagonal with rounded sides; slightly longer than wide; apex irregular, triangular to truncated; hinge narrower than greatest shell width; profile triangular; cicatrix usually large occupying from one-third to one-half valve length. Surface smooth with occasional undulations of growth.

Ventral valve deep, strongly truncated by the large cicatrix. Profile nearly flat, sides steeply rounded. Interior with short scoop-like hemispondylium attached to valve floor.

Dorsal valve lid-like, gently convex in both profiles; length three-fourths shell length. Interior with slender ascending apparatus. Lateral thickenings elevating posteriorly to make posterior of valve deeper than anterior.

MEASUREMENTS.-All measurements are in millimeters. 


$\begin{array}{lcccc}\text { USNM } & \text { Length } & \begin{array}{c}\text { Dorsal } \\ \text { valve } \\ \text { length }\end{array} & \text { Width } & \begin{array}{c}\text { Thick- } \\ \text { ness }\end{array} \\ 550815 \mathrm{a} & 1.7 & 1.4 & 1.8 & 1.1 \\ 550815 \mathrm{~b} & 1.7 & 1.3 & 1.5 & 1.2\end{array}$

Geological Occurrence.-Paleocene (Midway Formation, Clayton Member).

LocalmY.-Alabama 4.

TYPES.-Holotype USNM 550815a; paratypes: USNM $550815 \mathrm{~b}-\mathrm{e}$.

Discussion.-This is the smallest species of this genus so far discovered in the United States. It is suggestive of Thecidellina cooperi Toulmin (1940) of the Salt Mountain Limestone of Alabama but is smaller, narrower, and with a posteriorly deeper dorsal valve than that from the Salt Mountain Formation.

This species is slightly smaller than the Recent Thecidellina minuta Cooper (1981:61) from the Indian Ocean, which is the smallest living species known. The Alabama species has a larger cicatrix and a less attenuated triangular shape than the Indian Ocean species.

Thecidellina is known from the Caribbean, where it is common in shallow water attached to corallines. It is also known from the Eocene of the Pacific and in modern Pacific waters.

It is of interest to record that two of four specimens of Thecidellina cooperi (USNM 498438 and 498441) presented to the National Museum of Natural History by Dr. Toulmin belong to Lacazella, thus establishing the genus in the Wilcox Group (Salt Mountain Limestone). Furthermore, a paratype figured by Dr. Toulmin (1940, pl. 28: fig. 5) has the bulging pseudodeltidium of Lacazella. The remainder of the figures assigned to Thecidellina on Toulmin's plate 28 appear to be genuine Thecidellina, and these include the holotype.

Specimens of Thecidellina not identified as to species, were found at localities Alabama 3, North Carolina 3, and South Carolina 2.

\section{Localities}

\section{Alabama}

1. Paleocene (Wilcox Group, unnamed limestone below the Nanafalia Formation). USGS locality 25208, well near Brundidge Depot, Pike County.

2. Oligocene (Jackson Group, Zeuglodon Bed), Doctor Brown's field near Cocoa Post Office, Choctaw County.

3. Paleocene (Midway Group, Fort Gaines Formation), roadcut in $\mathrm{SW}^{1 / 4}$ section 26, T. 9 N., R. 28 E., Henry County.

4. Paleocene (Clayton Formation), $\mathrm{NW}^{1 / 4}$ section 12 , T. 8 N., R. 28 E, Henry County.

5. Oligocene (Jackson Group, Zeuglodon Bed), SW $\mathrm{SW}^{1 / 4}$ section 23, T. 11 N., R. 5 W., 2 miles $(3.2 \mathrm{~km})$ south of Melvin, 150 yards $(137 \mathrm{~m})$ east of north-south road, Choctaw County.

6. Oligocene (Jackson Group), USGS locality 2869, near Fail Post Office, Choctaw County.

7. Oligocene (Jackson Group), USGS locality 3892, Cocoa Post Office, Choctaw County.

\section{ANTARCTICA}

1. Recent, locality AH50, 64 $36^{\prime} \mathrm{S}, 54^{\circ} 03^{\prime} 29^{\prime \prime} \mathrm{W}$, Arthur Harbor, Palmer Peninsula at 50 feet $(15 \mathrm{~m})$ depth.

\section{NEW JERSEY}

1. Paleocene (Vincentown Formation), Stokely Canning Factory, north bank of South Branch of Rancocas Creek, 0.25 mile $(0.4 \mathrm{~km})$ west of east edge of Mount Holly $\left(7^{1} / 2^{\prime}\right)$ quadrangle.

\section{North Carolina}

1. Eocene (Castle Hayne Formation, probably Comfort Member), Wilmington, New Hanover County. According to Kellum (1926:9) collections labelled City Quarry (USGS 3602, 3609), New County Quarry, and Cemetery Quarry are from the same place to which he has given the number USGS 10613: East side Wilmington near Smith Creek. This number also includes USGS localities $1 / 340,307,782,2297,3602,3609,4285,5463,7797$. 65142, and Kellum 51.

2. Eocene (Castle Hayne Formation, Comfort Member), Ideal Cement Company Quarry, $34^{\circ} 22^{\prime} 33^{\prime \prime} \mathrm{N}, 77^{\circ} 50^{\prime} 20^{\prime \prime} \mathrm{W}, 7$ $\mathrm{km}$ northeast of Castle Hayne, New Hanover County. The quarry is now the type section of the Castle Hayne Formation (Ward et al., 1978:F6).

3. Eocene (Castle Hayne Formation), Maple-Lanier pit, $34^{\circ} 38^{\prime} \mathrm{N}, 77^{\circ} 44^{\prime} \mathrm{W}, 2.5$ miles $(4 \mathrm{~km})$ southeast of Maple Hill, Pender County.

4. Eocene (Castle Hayne Formation), 3.5 miles $(5.6 \mathrm{~km}$ ) northwest of Wrightsboro Depot, New Hanover County.

5. Eocene (Castle Hayne Formation), USGS locality 22329, pit 0.1 mile south on first dirt road of North Carolina Route 210 Lane Ferry Road, 0.1 mile west of Northeast Cape Fear River, Rocky Point $\left(7^{1} / 2^{\prime}\right)$ quadrangle.

6. Eocene (Castle Hayne Formation), Trask Farm, 2 miles $(3.2 \mathrm{~km})$ east of Rocky Point, Pender County.

7. Eocene (Castle Hayne Formation), East Coast Construction Company Quarry, 0.9 mile $(1.4 \mathrm{~km})$ southwest of junction of North Carolina Routes 50 and 53, 2 miles $(3.2 \mathrm{~km})$ west of Maple Hill, Pender County.

8. Eocene (Castle Hayne Formation), North Carolina Lime Company pit, 3.8 miles $(6.08 \mathrm{~km})$ west of Comfort, Jones County.

9. Eocene (Castle Hayne Formation), Martin-Marietta Company Castle Hayne Quarry (formerly Superior Stone 
Company Quarry), Superior Pit, 0.5 mile $(0.8 \mathrm{~km})$ north of North Carolina Route 1002, 2.3 miles (3.7 km) northeast of Castle Hayne, New Hanover County.

10. Eocene (Castle Hayne Formation), USGS 779, Rocky Point, Pender County.

\section{South Carolina}

1. Eocene (Santee Formation), 2 miles $(3.2 \mathrm{~km})$, above Lenuds Ferry on Santee River.

2. Eocene (Santee Formation), quarry of the Martin-Marietta Company, 2 miles $(3.2 \mathrm{~km})$ north of bridge crossing Santee River on South Carolina Route 41 and U.S. Route $17 \mathrm{a}$, on west side of road, $33^{\circ} 13^{\prime} 20^{\prime \prime} \mathrm{N}, 79^{\circ} 23^{\prime} 10^{\prime \prime} \mathrm{W}$, Georgetown County; 3.5 miles $(5.6 \mathrm{~km})$ northeast of Jamestown in Berkeley County.

3. Eocene (Cross Member of Santee Formation), USGS 25169, 25853, 25854, 25859, 25860, 25864. Superior Stone Company Quarry, near Cross, Berkeley County.

4. Eocene (Cross Member of Santee Formation), Martin-
Marietta Berkeley Quarry, Cross Pit, 1.5 miles (2.4 km) south of South Carolina Route 6-59 junction, just east of Route 59, near Cross, Berkeley County.

5. Oligocene (Ashley Member of Cooper Formation), USGS 26193, Giant Portland Cement Company Quarry at Harleyville, Dorchester County.

6. Eocene (Santee Formation), quarry on farm of Robert Edwards, east of South Carolina Route 6 at a point 1.2 miles $(1.9 \mathrm{~km})$ south of junction of South Carolina Routes 6 and 33, Berkeley County.

\section{VIRGINIA}

1. Pliocene (Yorktown Formation), Rice's Pit on west side of Harris Road, 0.25 mile $(0.4 \mathrm{~km})$ north of Fox Hill Road (Virginia highway 167), 1.4 miles (1.25 km) west of Bloxoms Corner, Hampton $\left(7^{1} / 2^{\prime}\right)$ quandrangle.

2. Pliocene (Yorktown Formation), Hampton Heights Dairy Pit, Hampton, Elizabeth City County. 


\section{Literature Cited}

Aldrich, T.H.

1907. Some New Eocene Fossils from Alabama. Nautilus, 21:8-11, plate 1.

1911. New Eocene Fossils from the Southern Gulf States. Bulletins of American Paleontology, 5(22):1-24, plates 1-5.

Backhaus, E.

1959. Monographie der cretacischen Thecideidae (Brachiopoda). Mitteilung geologische Staatsinstitut Hamburg, 28:5-90, 7 plates, 14 figures. Hamburg.

Clark, W.B.

1895. Two New Brachiopods from the Cretaceous of New Jersey. Johns Hopkins University Circular, 15(121):3, figures.

Clark, W.B., and G.C. Martin

1901. Molluscoidea: Brachiopoda. In Systematic Paleontology, Eocene, Maryland Geological Survey, Eocene, pages 203-204, plate 58.

Conrad, T.A.

1865. Catalogue of the Eocene and Oligocene Testacea of the United States. American Journal of Conchology, 1:1-35.

1875. Descriptions of New Genera and Species of Fossil Shells of North Carolina. In W.C. Kerr, Report on the Geological Survey of North Carolina, Raleigh, appendix A:18, plate 3: figures 1, [7?].

Cooper, G.A.

1959. Genera of Tertiary and Recent Rhynchonelloid Brachiopods. Smithsonian Miscellaneous Publications, 139(5): iv + 90 pages, 22 plates.

1971. Eocene Brachiopods from Eua, Tonga. United States Geological Survey Professional Paper, 640F:F1-F9, plate 1.

1977. Brachiopods from the Caribbean Sea and Adjacent Waters. Studies in Tropical Oceanography (Rosenstiel School of Marine and Atmospheric Science, University of Miami), 14:1-211, 35 plates.

1978. Teriary and Quaternary Brachiopods from the Southwest Pacific. Smithsonian Contributions to Paleobiology, 38:1-23, 4 figures, 2 plates.

1979. Tertiary and Cretaceous Brachiopods from Cuba and the Caribbean. Smithsonian Contributions to Paleobiology, 37:1-45, 2 figures, 7 plates.

1981. Brachiopoda from the Southern Indian Ocean (Recent). Smithsonian Contributions to Paleobiology, 43:1-93, 30 figures, 14 plates.

1982. New Brachiopods from the Southem Hemisphere and Cryptopora from Oregon (Recent). Smithsonian Contributions to Paleobiology, 41:1-43, 4 figures, 7 plates.

1983. The Terebratulacea (Brachiopoda), Triassic to Recent: A Study of the Brachidia (Loops). Smithsonian Contributions to Paleobiology, 50:1-445, 17 figures, 77 plates.

Dall, W.H.

1870. A Revision of the Terebratulidae and Lingulidae with Remarks on and Descriptions of some Recent Forms. American Journal of Conchology, 6(2):88-168, figures 1-38, plates 6-8.

1871. Supplement to the Revision of the Terebratulidae with Additions, Corrections, and a Revision of Craniidae and Discinidae. American Journal of Conchology, new series, 7(2):39-85, plates 10, 11.

1900. Some Names which Must be Discarded. Nautilus, 14(4):44-45.

1903. Contributions to the Tertiary Fauna of Florida. Transactions of the Wagner Free Instituse of Science, 3(6):1533-1540, plate 58.

de Gregorio, A.

1890. Monographie de la fauna l'eocénique de l'Alabama et surtout de celle de Claiborne de l'étage Parisien. Annale de Geologie et de Paléontologie, 7-8:1-316, plates 1-46.

d'Orbigny, A.

1847. Considérations zoologiques et géologiques sur les Brachiopodes ou Palliobranches. Comptes Rendus de l'Académie Science de Paris, 25(5):193-195, (7)266-269.

Fischer, P., and D.P. Oehlert

1890. Diagnoses de nouveaux Brachiopodes. Journal de Conchiliologie, series 3, 38(1):70-74

Gardner, J.

1925. A New Midway Brachiopod, Butler Salt Dome. American Journal of Science, series 5, 10:134-138, figures 1-8.

Gray, J.E.

1840. Synopsis of the Contents of the British Museum. 42nd edition, 370 pages. London.

1848. On the Arrangement of the Brachiopoda. Annals and Magazine of Natural History, series 2, 2:435-440.

Hertlein, L.G., and U.S. Grant IV

1944. The Cenozoic Brachiopoda of Western North America. Publications of the University of California at Los Angeles in Mathematical and Physical Sciences, 3: 236 pages, 34 figures, 21 plates.

Huxley, T.H.

1869. An Introduction to the Classification of Animals. 147 pages, 47 figures. London: John Churchill and Sons.

Jackson, J.W

1912. The Brachiopoda of the Scottish National Antarctic Expedition. Transactions of the Royal Society of Edinburgh 48(2):367-390, plates $1,2$.

Jaekel, O.M.J.

1902. Ueber Verschiedene Wege Phylogenetischer Entwickelung. In Verhandlungen des V Internationalen Zoologen Congress zu Berlin, 12-16 August 1901, pages 1058-1117, 28 figures. Jena: Gustav Fischer.

Kellum, L.B.

1926. Paleontology and Stratigraphy of the Castle Hayne and Trent Marls in North Carolina. United States Geological Survey Professional Paper, 143:1-56, 11 plates.

1931. Revision of the Names of Three Fossils from the Castle Hayne and Trent Marls in North Carolina. Journal of the Washington Academy of Sciences, 21(4):51-52.

King, W.

1850. A Monograph of the Permian Fossils of England. Palaeontographical Society Monograph (London), 3:xxxvii + 258 pages, 29 plates.

Kuhn, O.

1949. Lehrbuch der Paläozoologie. 326 pages, 244 figures. Stuttgart: E. Schweitzerbart.

Lyell, C., and G.B. Sowerby

1845. In C. Lyell, Observations on the White Limestone and Other Eocene or Older Tertiary Formations of Virginia, South Carolina, and Georgia. Quarterly Journal of the Geological Society of London, 1:429-442, figure b [on page 431]

Menke, C.T.

1828. Synopsis Methodica Molluscorum Generum Omnium et Specierum earum quae in Museo Menkeano Adservantor. 91 pages. Pyrmonti.

Morton, S.G.

1833. Supplement to the Synopsis of the Organic Remains of the Ferruginous Sand Formation of the United States. American Journal 
of Science, 24(11):128-132, plates 9, 10.

1834. Synposis of the Organic Remains of the Cretaceous Group of the United States. 88 pages, 19 plates. Philadelphia.

Muir-Wood, H.M.

1955. A History of the Classification of the Phylum Brachiopoda. Volume 7, 124 pages, 12 figures. London: British Museum (Natural History).

Munier-Chalmas, $M$.

1880. Sur quelques genres des Brachiopodes. Bulletin Société Géologique de France, 8(4):279-280.

Olsson, A.

1914. New and Interesting Neocene Fossils from the Atlantic Coastal Plain. Bulletins of American Paleontology, 5(24): 3-34, 12 plates.

Pajaud, D.

1970. Monographie des Thécidées (Brachiopodes). Mémoires de la Société Géologique de France, new series, 49(112): 349 pages, 16 plates, 140 figures.

Ravenel, E.

1844. Description of Some New Species of Fossil Organic Remains, from the Eocene of South Carolina. Proceedings of the Academy of Natural Sciences of Philadelphia, 2(5):96-98.

Retzius, A. J.

1781. Crania oder Todenkopfs-Muschel. Schriften der Berlin Gesellschaft Nalurforschende Freunde, 2:66-76, plate 1.

Schuchert, C.

1897. A Synopsis of American Fossil Brachiopoda, Including Bibliography and Synonymy. Bulletin of.the United States Geological Survey, 87: 464 pages, 10 tables.

Stenzel, H.B.

1940. New Eocene Brachiopods from the Atlantic Coastal Plain University of Texas Publication, 3945:717-730, plate 34.

1943. Type Invertebrate Fossils of North America: Brachiopoda, Eocene, cards 122-148. Austin, Texas: Bureau of Economic Geology.

1964. Stratigraphic and Paleontologic Significance of a New Danian Brachiopod Species from Texas. Sonderabdruck aus der Geologischen Rundschau, 54:619-631, 5 figures.
Thomson, J.A.

1915. A New Genus and Species of the Thecideinae. Geological Magazine, 6(2):461-464.

1916. Additions to the Knowledge of the Recent and Tertiary Brachiopoda of New Zealand. Transactions and Proceedings of the New Zealand Institufe, 48:41-47, plate 1 .

1926. A Revision of the Subfamilies of the Terebratulidae (Brachiopoda). Annals and Magazine of Natural History, series 9, 18:523-530.

Toulmin, L.D.

1940. Eocene B rachiopods from the Salt Mountain Limestone of Alabama. Journal of Paleontology, 14(3):227-233, plate 28

Tunnell, J.W., Jr.

1972. Crania sp. (Brachiopoda) from Texas Waters. Texas Journal of Science, 23(4):553. [Crania sp. is now regarded as Discradisca (Tunnell, letter, 17 September 1984).]

Waagen, W.H.

1882-1885. Salt Range Fossils, Part 4(2): Brachiopoda. Palaeontographica Indica, Memoir, series 13, vol. 1:329-770, plates 25-86 [Fascicle 1:329-390; plates 25-28, 1882; Fascicle 2:391-546, plates 29-49, 1883; Fascicle 3:547-610, plates 50-57; 1884; Fascicle 4:611-728, plates 58-81, 1884; Fascicle 5:729-770, plates 82-86, 1885].

Ward, L.W., D.R. Lawrence, and B.W. Blackwelder

1978. Stratigraphic Revision of the Middle Eocene, Oligocene, and Lower Miocene-Atlantic Coastal Plain of North Carolina. Contributions to Stratigraphy [U.S.] Geological Survey Bulletin, 1457-F:F1-F23.

Weller, $S$.

1907. A Report on the Cretaceous Paleontology of New Jersey Based on the Stratigraphic Studies of George N. Knapp. New Jersey Geological Survey, Paleontological Series, 4:3-1106, 111 plates.

Whitfield, R.P.

1885. Brachiopoda and Lamellibranchiata of the Raritan Clays and Greensand Marls of New Jersey. United States Geological Survey Monograph 9:5-388, 35 plates. 
Plates 1-9 


\section{PLATE 1}

FIGURES 1-4.-Argyrotheca semicostata, new species: side, dorsal, ventral, and anterior views, $\times 7.5$, of holotype USNM 551503. (Locality: North Carolina 3)

FIGURES 5-8.-Argyrotheca beecheri (Clark): ventral, side, anterior, and dorsal views, $\times 10$, of a specimen showing strong, direct costae, hypotype USNM 551523a. (Locality: New Jersey 1)

FIGURES 9-14.-Terebratulina brundidgensis Aldrich: 9, dorsal view, $\nsim 2$, of a paralectotype, USNM 639038; $10-13$, anterior, side, ventral, and dorsal views, $\times 2$, of a large specimen showing costellae, hypotype USNM 551519a; 14, interior of dorsal valve showing stout loop, $\times 3$, hypotype USNM 551519b. (Locality: Alabama 1)

FIGURE 15.-Terebratulina wilsoni, new species, dorsal exterior, $\times 3$, showing costellae in detail, holotype USNM, 551515a. (Locality South Carolina 4) (See Plate 6: figure 34)

FIGURE 16.-Terebratulina lachryma (Morton), dorsal exterior, $\Varangle 3$, showing ornament, hypotype USNM 551516a. (Locality: South Carolina 2)

Figures 17-32. -Glottidia inexpectans Olsson: 17, 18, an adult dorsal valve exterior and interior, $\times 1$, hypotype USNM 551531; 19,20, posterior of interior of a ventral valve, $\times 1, \times 2$, showing strong diverging ridges, hypotype USNM 551520a; 21, 22, exterior of two ventral valves, $x 1$, hypotypes USNM $551520 \mathrm{~b}, \mathrm{c} ; 23$, ventral view of a young specimen preserving both valves, $\times 1$, hypotype USNM 551520d; 24, 25, interior of a dorsal valve, $\times 2, \times 1$, showing shon solid beak and median ridge, hypotype USNM 551520e; 26, another fragmentary dorsal valve showing solid beak, median ridge and paired muscle scars, $\times 2$, hypotype USNM 551520f; 27, ventral valve interior, $\times 1$, showing divergent ridges, hypotype USNM 551520-1; 28, large ventral valve, $\times 1$, hypotype USNM 551520g; 29,30 , interior and exterior of dorsal valve, $\times 1$, having bevelled boring on one side, hypotype USNM 551520h; 31, 32, large ventral valve, exterior and interior, $\times 1$, hypotype USNM 551520i. (Locality: Virginia 1) 

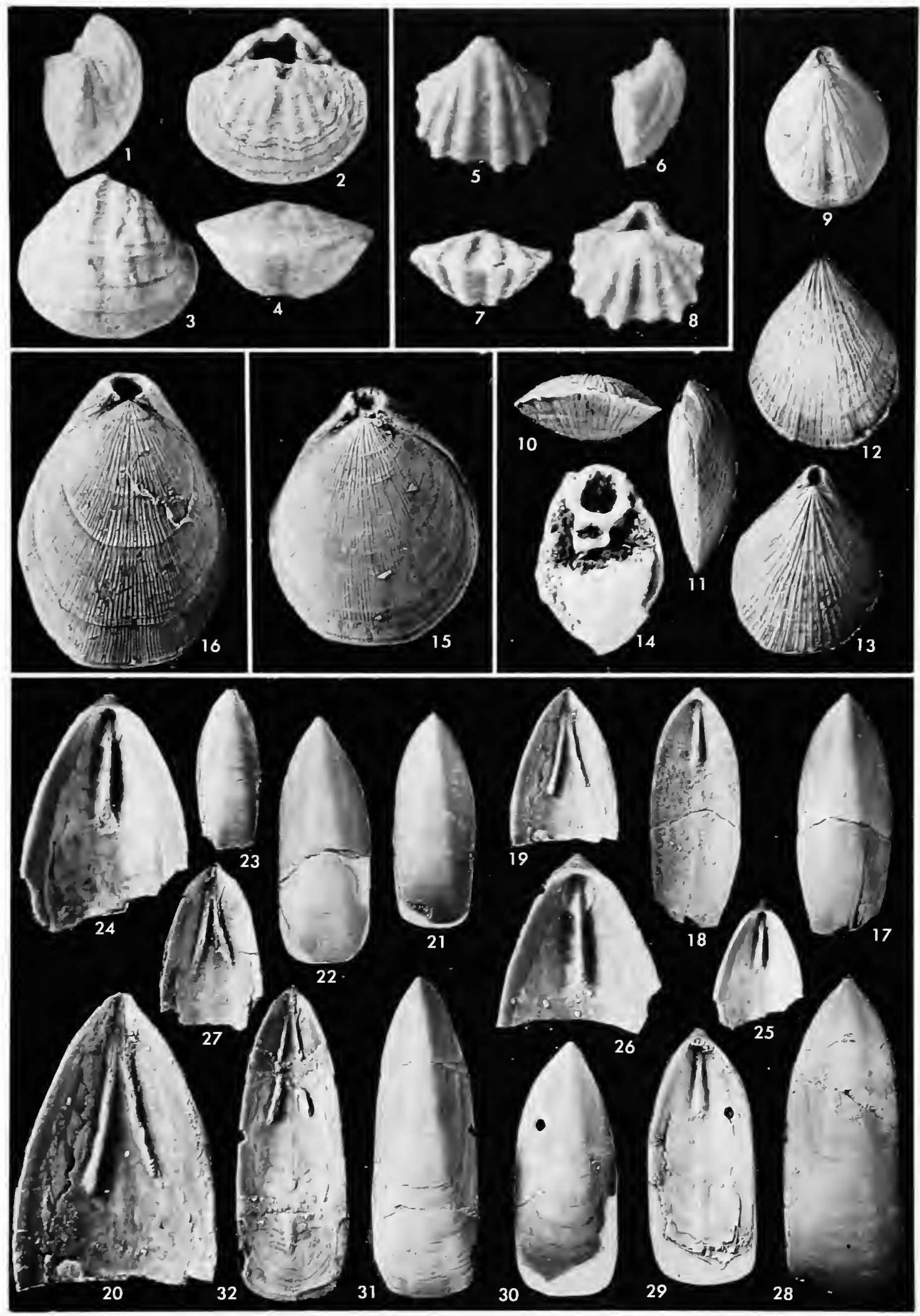
PLATE 2

FiguREs 1-8.-Argyrotheca quadrata, new species: $1-4$, dorsal, anterior, side, and ventral views, $\times 10$, hypotype USNM 551007a; 5-8, side, ventral, anterior, and dorsal views, $\times 10$, showing anteriorly intercalated costae, hypotype USNM 551007b. (Locality: South Carolina 2)

FIGURES 9-17.-Probolarina holmesi santeensis, new subspecies: 9-12, Dorsal view, $\times 1$, and anterior, side and dorsal views, $\times 2$, holotype USNM 551518a; $13-16$, dorsal view, $\times 1$, and side, dorsal, and anterior views, $\chi 2$, paratype USNM 551518b; 17, ventral view, $\times 3$, of a specimen having falcifer crura, paratype USNM 551518f. (Locality: South Carolina 2)

FIGURES 18-29.-Plicatoria wilmingtonensis (Lyell and Sowerby), group showing variation of costation: 18-21, ventral, side, anterior, and dorsal views, $\times 1$, of a specimen with four anterior costae, hypotype USNM 550866; $22-25$, side, ventral, anterior, and dorsal views, $\times 1$, of a specimen having six costae on dorsal valve, hypotype USNM 550878; 26-28, side, dorsal, and anterior views, $\times 1$, of another specimen with six costae, hypotype USNM 550870; 29, interior of dorsal valve, $\times 3$, showing cardinalia and rare inner hinge plates, hypotype USNM 550914b. (Localities: 18-21, 26-28, North Carolina 1; 22-25, North Carolina 5)

FIGUREs 30-46.-Probolarina transversa, new species: 30-33, dorsal view, $\times 1$, and side, anterior, and dorsal views, $\chi 2$, of the holotype USNM 551517a; 34-37, dorsal view, $\times 1$, and anterior, side and dorsal views, $\varnothing 2$, paratype USNM $551517 \mathrm{~b} ; 38-41$, dorsal view, $\times 1$, and anterior, side, and dorsal views, $\times 2$, of the paratype USNM 551517c; 42 , interior of dorsal valve, $\chi 3$, from dorsal side, showing short falcifer crura, paratype USNM 551517d; 43 , dorsal valve seen from dorsal side, $\times 3$, showing broad falcifer crura, paratype USNM $551517 \mathrm{e} ; 44,45$, dorsal and side views, $\times 3$, of the posterior of holotype; 46 , side view, $\times 3$, of posterior of paratype USNM 551517b. (Locality: South Carolina 2) 

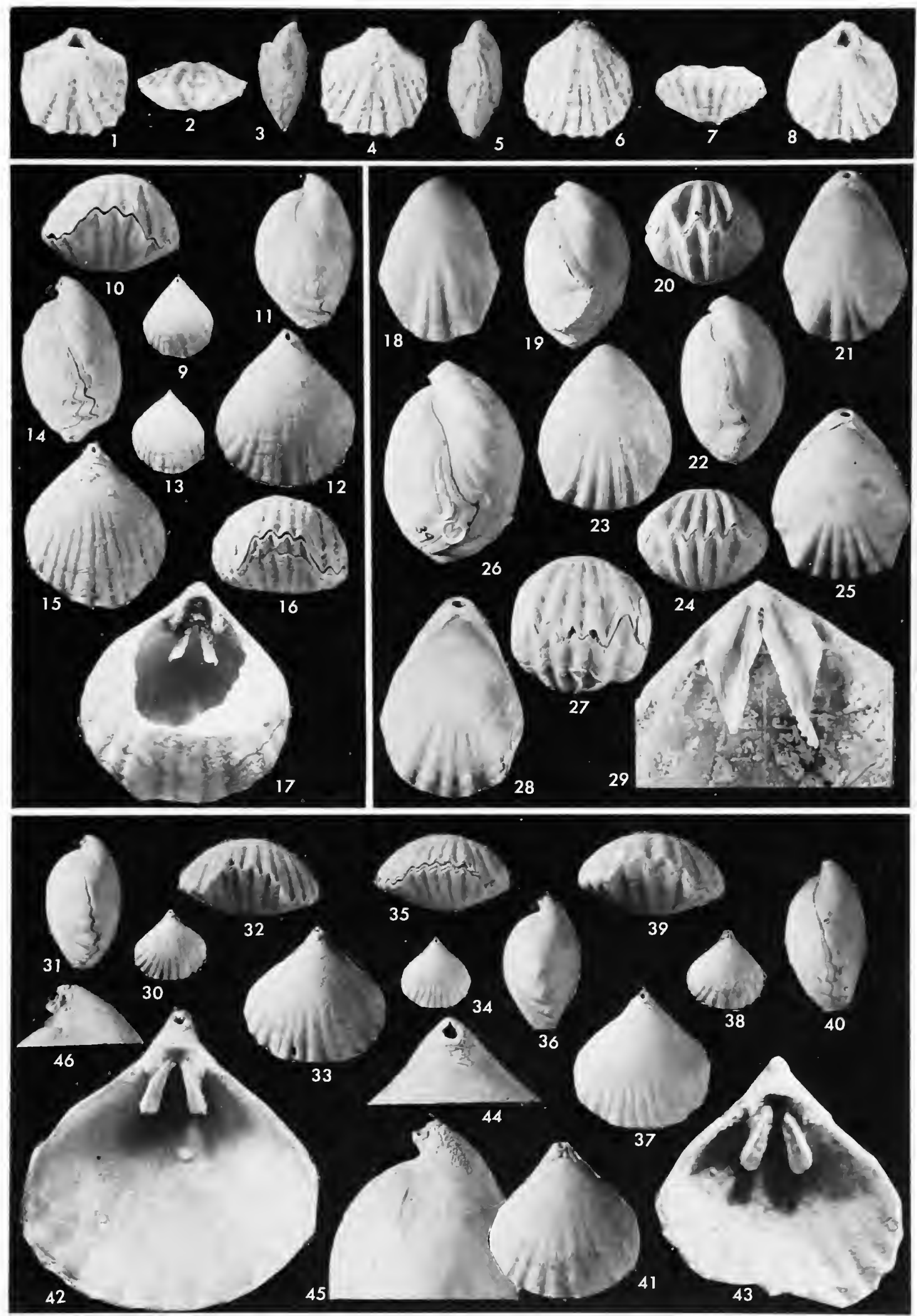


\section{PLATE 3}

FIGURES 1-4.-Terebratulina brundidgensis Aldrich syntype (now paralectotype) USNM 639038: 1, dorsal view, $\times 1$, showing narrow median sulcus; $2-4$, dorsal, anterior, and side views, $\times 2$. (Locality: Alabama 1)

FIGUREs 5-7.-Probolarina brevirostris, new species, side, anterior, and ventral views, $\varnothing 2$, holotype, USNM 551527. (Locality: North Carolina 7)

FIGURE 8.-Isocrania? species 1 , interior of ventral valve, $\times 3$, showing median elevation and muscle sears, USNM 551510. (Locality: South Carolina 3)

FIGURES 9, 10.-Isocrania? species 2, dorsal and ventral views $\times 3$, of a flattish dorsal valve showing anterior and posterior muscle scars, USNM 551528. (Locality: South Carolina 5)

FIGUREs 11-15.-Terebratulina lachryma (Morton), hypotype, USNM 551526a: 11, dorsal view of complete specimen, $\times 1 ; 12-15$, anterior, dorsal, side, and ventral vicws showing fine costellae, $\times 2$. (Locality: South Carolina 2)

FIGUREs 16-19.-Terebratulina brundidgensis Aldrich, ventral, anterior, side, and dorsal views, $\times 1$, of Aldrich's syntype USNM 639036, now lectotype of the species. (Locality: Alabama 1)

FIGUREs 20-29.-Terebratulina species: 20-22, side, dorsal, and anterior views, $\chi 2$, of a young adult USNM $145613 a ; 23-25$, dorsal, side, and anterior views, $\times 2$, of a young adult USNM 145613b; 26-28, side, anterior, and dorsal views, $\times 2$, of a young specimen USNM 145613c; 29, excavated specimen showing loop with its parallel crura and narrow ring, $\times 3$, USNM 145613d. (Locality: Alabama 6)

FIGUREs 30-36.-Plicatoria parva, new species: 30-32, dorsal, side, and antcrior views, $\times 1$, paratype USNM $551529 \mathrm{~b} ; 33$, dorsal view, of paratype USNM $551529 \mathrm{~b} ; \times 2 ; 34,35$, dorsal views, $\times 1, \times 2$ of the holotype USNM 551529a; 36 , interior view of the holotype, $\times 2$, showing imperfect loop with its extremely long outer hinge plates. (Locality: South Carolina 3)

FIGURES 37-41.-Terebratulina capillata, new species, dorsal view, $\times 1$, and anterior, ventral, side, and dorsal views, $\times 2$, showing widely oval outline and fine costellae, paratype USNM 551525a. (Locality: North Carolina 2)

FIguRes 42-46. - Rhytisoria alabamensis Cooper: 42-45, dorsal, anterior, side, and ventral views, $\times 1$, holotype USNM 549392a; 46, dorsal valve interior, $\times 2$, showing loop, paratype USNM 549392b. (Locality Alabama 1). (lllustrated for comparison with Plicatoria wilmingtonensis (Lyell and Sowerby) with which it has been confused.) 

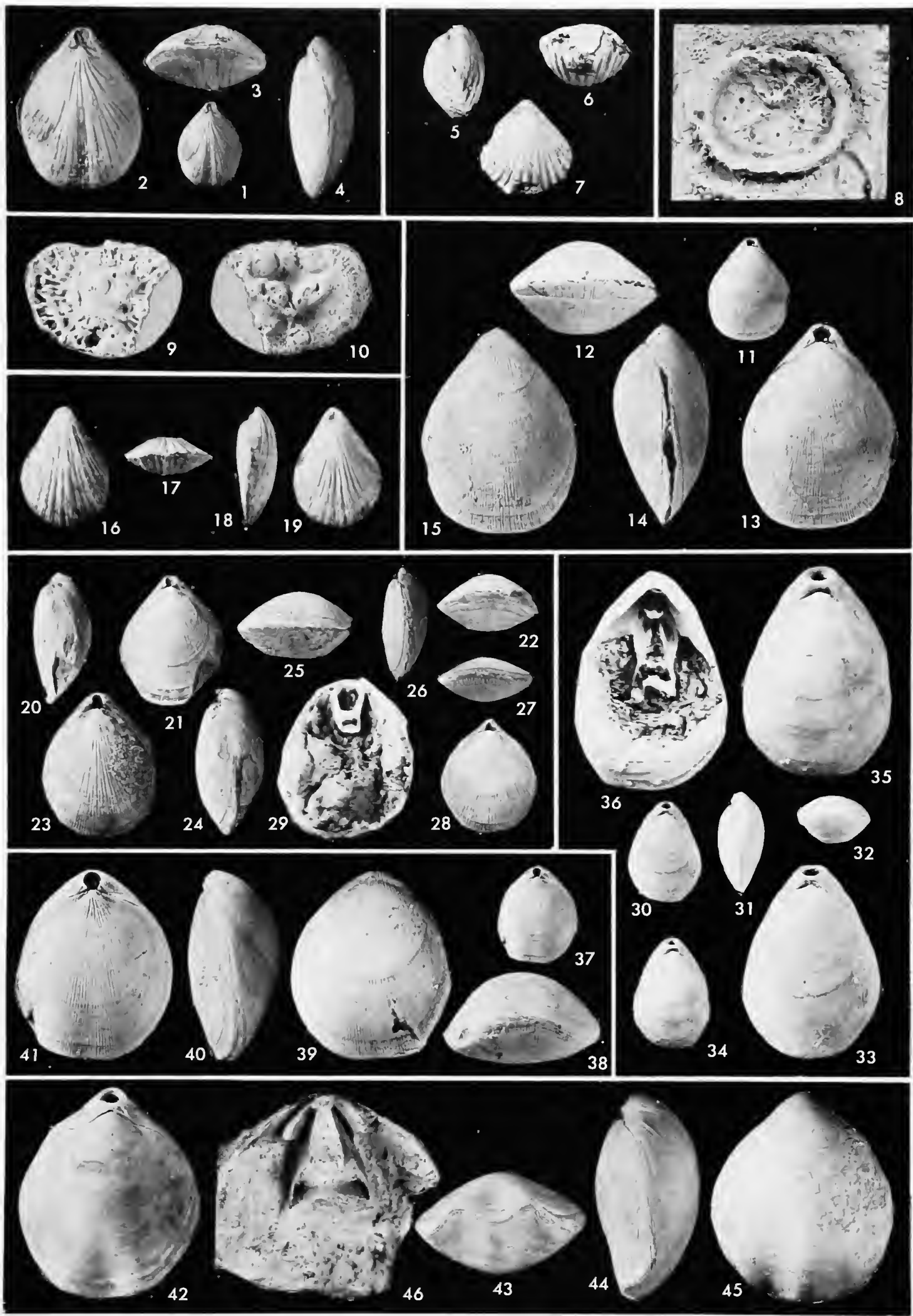


\section{PLATE 4}

FiguREs 1-23.-Argyrotheca macneili, new species: 1-5, ventral, anterior, dorsal, side, and posterior views, $\times 6$, paratype USNM 550458b; 6-10, ventral, dorsal, side, posterior, and anterior views, of a specimen showing traces of a loop (figure 9), $\times 6$, holotype USNM 550458a; 11-15, ventral, side, anterior, posterior and dorsal views, $\times 6$, paratype USNM 550458c; 16,17, side and dorsal views of a specimen smaller than the preceding, $\times 6$, paratype USNM 550458d; 18-20, dorsal views of the ventral valve interior showing apical plate and median septum, $\times 6$, of 3 paratypes USNM 550458e-g; 21-23 ventral views of the interior of 3 dorsal valves, $\times 6$, paratypes USNM 550458h-j. (Locality Alabama 3)

Figures 24-30.-Lacazella nana, new species: 24-26, dorsal, side, and ventral views, $\times 10$, showing raised pseudodeltidium (?), holotype USNM 549362a; 27, dorsal view of a complete specimen, $\times 10$, paratype USNM 549362b; 28 , dorsal view of a ventral valve showing teeth and swollen pseudodeltidium (?), $\times 10$, paratype USNM 549362c; 29, 30, interior of two dorsal valves, $\times 10$, paratypes USNM 549362d, e. (Locality: Alabama 4)

FIGURES 31-39.-Thecidellina alabamensis, new species: 31-33, Dorsal, ventral, and side views, $\times 9$, holotype USNM 550815a; 34-36, ventral, side, and dorsal views, $\times 9$, showing flat interarea (figure 36 ) and broad attachment surface (figure 35), paratype USNM 550815b; 37, interior of a dorsal valve, about $\times 12$, showing large cardinal process and narrow median pillar, paratype USNM 550815c; 38, interior of dorsal valve, about $\times 10$, paratype USNM 550815d; 39, exterior of dorsal valve, about $\times 10$, paratype USNM 550815e. (Locality: Alabama 4)

Figures 40-44.-Argyrotheca quadrata, new species: 40, 41, dorsal exteriors showing intercalated costae, $\times 10$, hypotypes USNM 551508a, b; 42, 43, dorsal interiors showing imperfect loop and septa, $\times 10$, hypotypes $551508 \mathrm{c}, \mathrm{d} ; 44$, interior of a ventral valve, $\times 10$, showing septum with anterior pit, hypotype USNM $551508 \mathrm{e}$. (Locality: South Carolina 3)

FIGURE 45.-Liothyrella notorcadensis (Jackson), cluster of adults with attached young, $\times 1$, suggesting way Plicatoria may have lived. Such clustering may have contributed to some of the variation of Plicatoria, especially the young; hypotype USNM 550885. (Locality: Antarctica 1)

FIGURES 46-52.-Argyrotheca quadrata transversa, new subspecies; 46-48, dorsal, ventral, and posterior views, $\times 10$ of a small specimen, paratype USNM $551505 \mathrm{~b}$; 49-52, anterior, dorsal, side, and ventral views of a specimen larger than the preceding paratype, $\times 10$, holotype USNM 551505a. (Locality: North Carolina 3) 

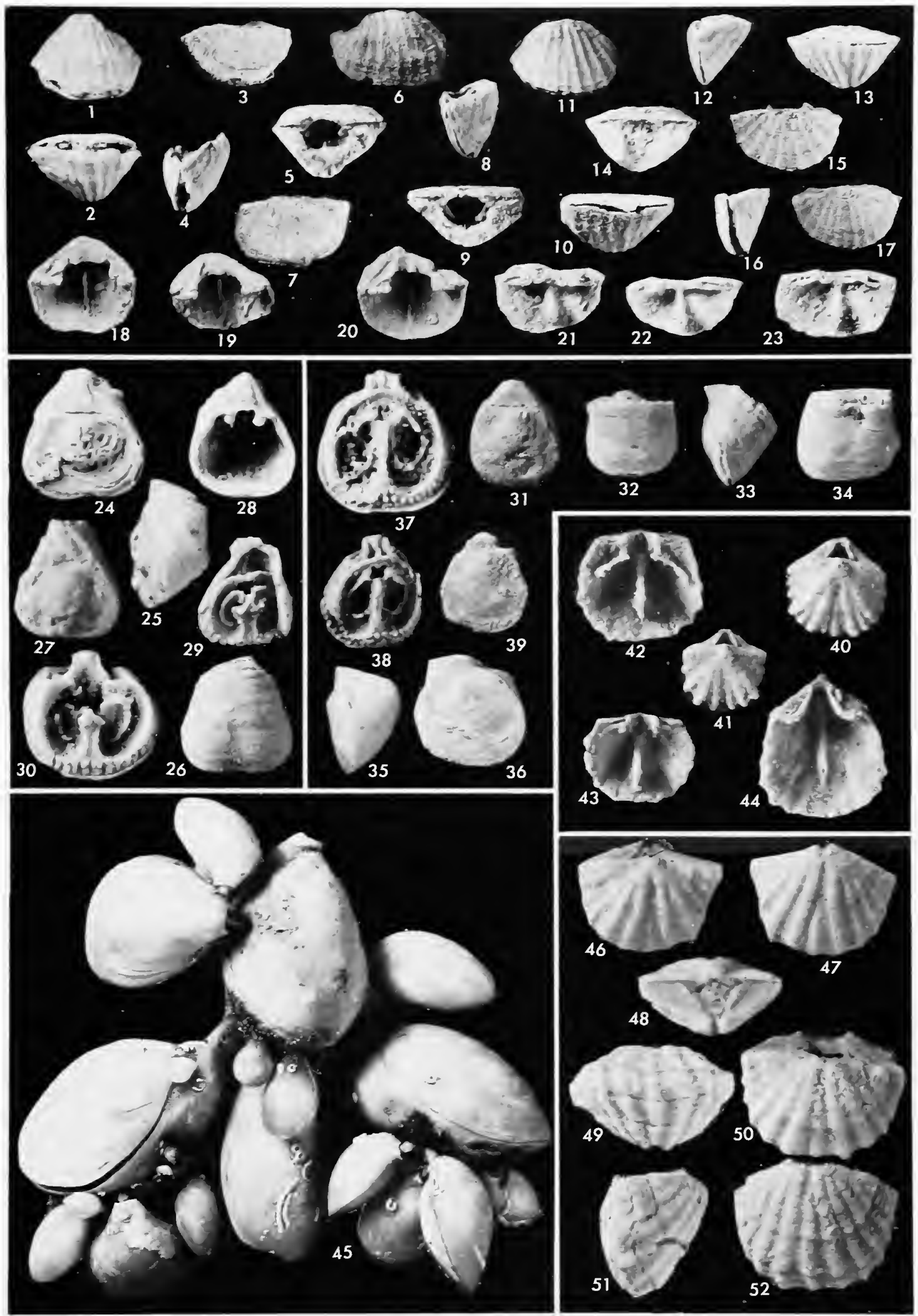


\section{PLATE 5}

FIGUREs 1-3.-Crania? species 2, dorsal, side, and interior views of a dorsal valve, $\times 3$, USNM 549410. (Locality: Norh Carolina 1)

FIgURES 4-6.-Crania? species 1 , interior, side, and dorsal views, $\times 3$, of a dorsal valve showing muscle scars (figure 4), USNM 549401. (Locality: North Carolina 1)

FIGUREs 7-11.-Terebratulina capillata, new species: 7-10, four immature specimens showing strong beading on costellae characteristic of young specimens, $\times 4$, paratypes USNM 550882a, c, d, b; 11 , young specimen showing loop, $\times 3$, paratype USNM 550882e. (Locality: Nonth Carolina 1)

FigUREs 12-25.-Argyrotheca quadrala, new species: 12-17, posterior, anterior, side, dorsal, and ventral views, $\times 6$, and dorsal view, $\times 9$, showing intercalated costae, paratype USNM 550881a; 18-23, side, anterior, posterior, ventral, and dorsal views, $\times 6$, and dorsal view, $\times 9$, holotype USNM 550881b; 24 , interior of the ventral valve, $\times 9$, paratype USNM 550881d; 25 , interior of the dorsal valve, $\times 9$, paratype USNM 550881c. (Locality: North Carolina 1)

Figures 26-28.-Terebratulina lachryma (Morton): 26 , dorsal view of a medium sized specimen, $\times 3$, hypotype USNM 550883a; 27, 28, exterior and interior showing loop of a smaller specimen than the preceding, $x 3$, hypotype USNM 550883b. (Locality: South Carolina 1)

Figures 29-40.-Terebratulina capillata, new species: 29-33, dorsal view, $\times 1$, and dorsal, anterior, side, and ventral views, $\chi 2$, showing fairly even costellae of a young specimen, paratype USNM 550814a; 34-38, dorsal view, $\times 1$, and anterior, side, dorsal, and ventral views, $\chi 2$, holotype USNM 550814b; 39, ventral view of the dorsal interior showing the loop, $\times 3$, paratype USNM 550814c; 40, dorsal valve showing loop, $\times 3$, paratype USNM 550872. (Locality: North Carolina 1)

FIGURES 41-44.- Eucalathis? species 1, anterior, ventral, dorsal, and side views of a finely costate specimen, $\times 10$, USNM 551511. (Locality: South Carolina 3)

FiguRes 45-50.-Eucalathis? species 2: 45-48, ventral, side, anterior, and dorsal views, $\times 10$, of a specimen with beaded costae, USNM 550886a; 49 , interior of ventral valve, $\times 10$, USNM 550886b; 50, dorsal valve interior showing typical cancellothyridid cardinalia, $\times 10$, USNM 550886c. (Locality: North Carolina 1) 

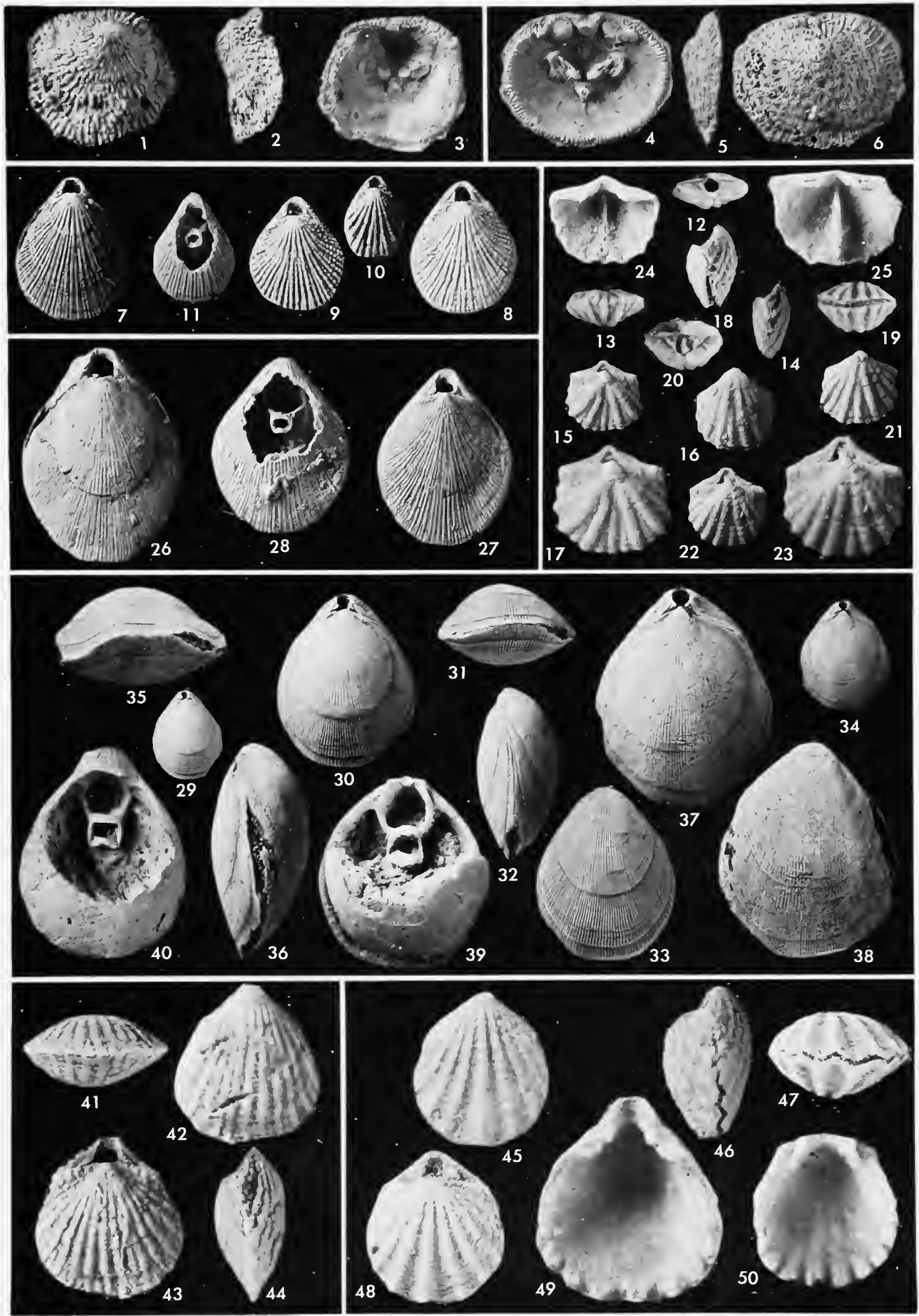


\section{PLATE 6}

FIGURE 1.-Isacrania? species 1, exterior of dorsal valve, $\times 4$, USNM 551510. (Locality: South Carolina 3)

FIGURES 2, 3.-Isocrania? species 2 , exterior and interior of a strongly marked dorsal valve, $\times 5$, USNM 551509. (Locality: South Carolina 3)

FIGURE 4.-Isocrania? species 1 , interior of a ventral valve, $\times 4$, USNM 551512. (Locality: South Carolina 3)

FIGURES 5-13.-Terebratulina alabamensis, new species: 5-8, dorsal view, $\times 1$, and dorsal, side, and anterior views, $\chi 2$, holotype USNM 141028a; 9-12, dorsal view, $\times 1$, and dorsal, side, and anterior views, $\times 2$, paratype USNM 141028b; 13 , ventral view, $\nsim$, of the posterior of a dorsal valve showing stout loop, paratype USNM 141028c. (Locality: Alabama 2)

FIGUREs 14-21.-Terebratulina lachryma (Morton): 14-17, dorsal view, $x \mathrm{l}$, and dorsal, anterior, and side views, $\times 2$, of a large specimen, hypotype USNM 551514b; 18,19, dorsal and anterior views, $\times 2$, of a specimen rounder than the preceding, hypotype USNM 551514c;20,21, interior of two dorsal valves, $\times 3$, seen from the ventral side, hypotypes USNM 551514d, c. (Locality: South Carolina 3)

FIGUREs 22-28.-Terebratulina lachryma (Monon): 22-25, dorsal view, $\times 1$, and dorsal, anterior, and side views, $\chi$, of a large, elongate specimen, hypotype USNM 551516a; 26-28, specimens prepared to show the slender loop, $\times 2, \times 3, \times 2$, hypotypes USNM 551516b, c, d. (Locality: South Carolina 2)

FIGUREs 29-36.-Terebratulina wilsoni, new species: 29-31, Dorsal, side, and anterior views, $\chi 2$, holotype USNM 551515a; 32-34, anterior, side, and dorsal views, $\times 2$, holotype USNM 551515a; 35 , interior of a dorsal valve showing slender loop, $\times 3$, paratype USNM 551515c; 36 , ventral view of dorsal valve, $\chi 3$, showing loop with crural processes not meeting to form usual ring, paratype USNM 551513. (Localities: 29-35, South Carolina 4; 36, South Carolina 3)

FIGUREs 37-40.-Plicatoria ventricosa, new species: $37-39$, anterior side, and dorsal views, $\times 1$, holotype USNM 551498a; 40, dorsal valve excavated to show loop with its long outer hinge plates, $\times 1.5$, paratype USNM 551498f. (Locality: North Carolina 2) 

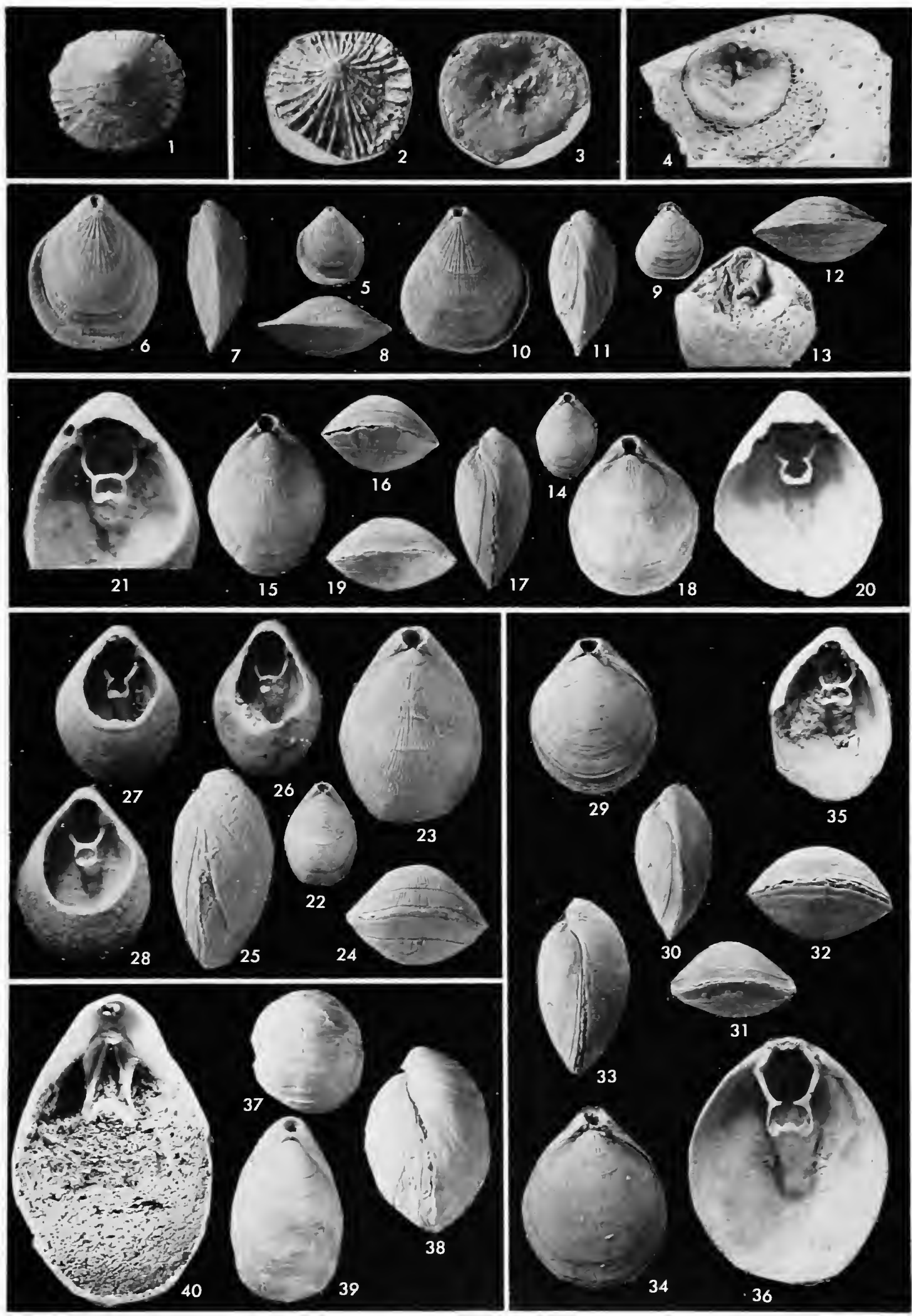


\section{PLATE 7}

FIGUREs 1-28.-Plicatoria wilmingtonensis (Lyell and Sowerby): 1-4, anterior, ventral, side, and dorsal views, $\times 1$, of a large, narrow specimen (type B) with 6 costae on fold, hypotype USNM 549389i; 5-8, dorsal, side, anterior, and ventral views, $\times 1$, of an anteriorly expanded form with four median costae and three on the flanks, hypotype USNM 549389e; 9-12, ventral, anterior, dorsal, and side views, $\times 1$, of an exceptionally narrow specimen with only three angular costae and an intercalated fourth costa, hypotype USNM 549389-1; 13-16, dorsal, side, anterior, and ventral views, $\times 1$, of an anteriorly widened specimen (type A), with six median costae, two short intercalations, two costae on one flank, three on the opposite one, hypotype USNM $549389 \mathrm{c} ; 17-20$, side, anterior, ventral, and dorsal views, $\times 1$, of a narrow individual with five anterior costae, hypotype USNM 549389f; 21-24, ventral, side, anterior, and dorsal views of a widely expanded specimen, $\times 1$, with costae of different sizes, hypotype USNM 549389d; 25, a large young specimen that has not yet developed costae, $\times 1$, hypotype USNM 549427 (figured by Dall 1903, pl. 58: fig. 14); 26, young specimen showing dorsal valve interior, $\chi 2$, hypotype USNM $549389 \mathrm{~m} ; 27,28$, loops of two adult specimens, $\chi 2$, hypotypes USNM 549389g, 550875, the former with incipient inner hinge plates. (Locality: all from North Carolina 1) 


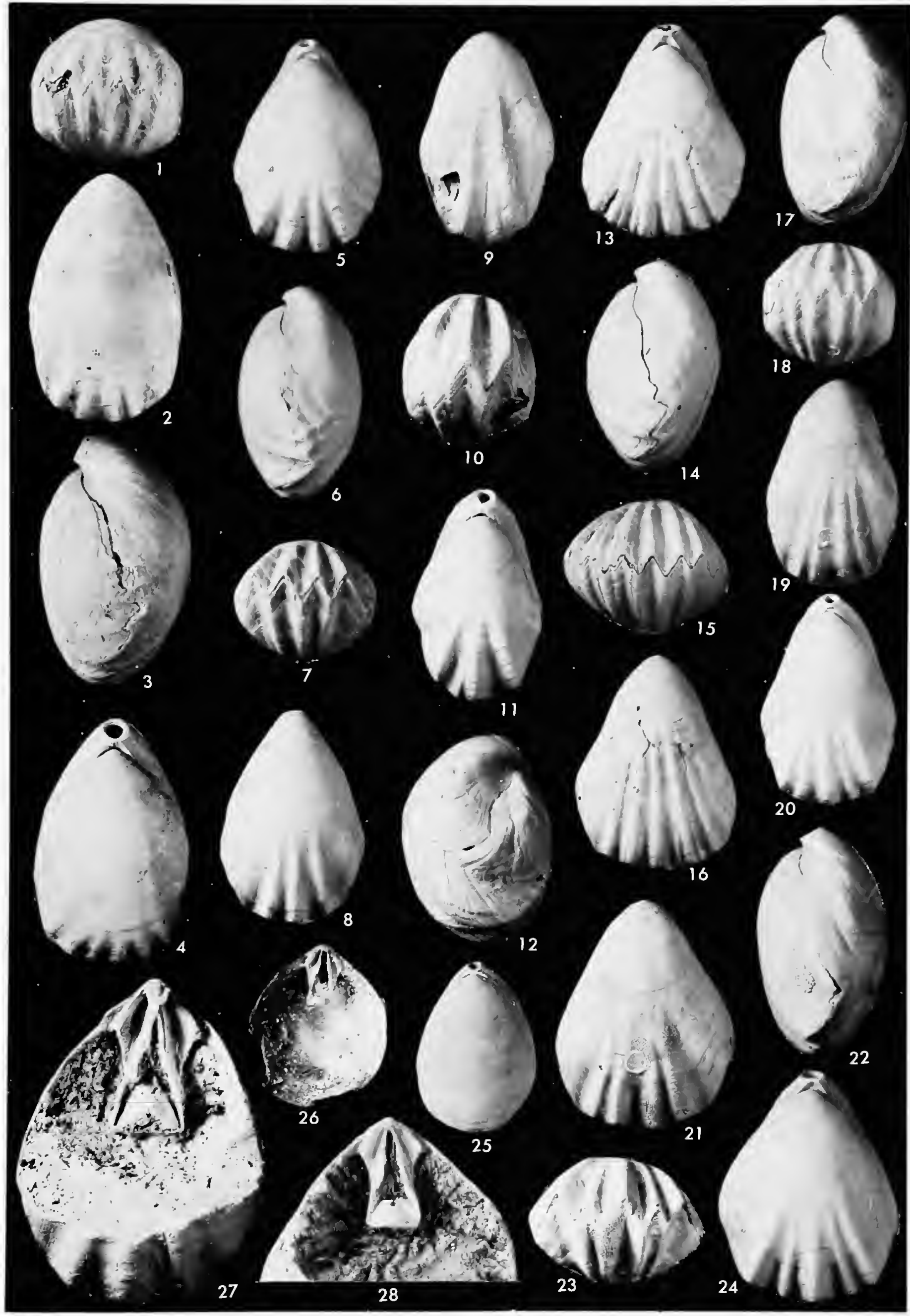




\section{PLATE 8}

FIGURES 1-33.-Plicatoria wilmingtonensis (Lyell and Sowerby); 1-4, ventral, dorsal, anterior, and side views, $\times 1$, of a large, anteriorly expanded individual (type A), with four median costae (figure 4 with ventral side up to show wide dorsal sulcus), hypotype USNM 549389h; 5-8, side, ventral, dorsal, and anterior views, $\times 1$, of a small specimen with four median costae, hypotype USNM 550874; 9-12, dorsal, anterior, ventral, and side views, $\times 1$, of the most unusual specimen having two strong plications on the dorsal valve, one median plication on the ventral valve, and three costae on one flank (type D), hypotype USNM 549389k; 13-15, anterior, dorsal, and side views, $\times 1$, of an anteriorly expanded specimen with six median costae, hypotype USNM 551495a; 16-18, side, dorsal, and anterior views, $\times 1$, of a small specimen with three median costae, hypotype USNM 551499; 19-21, side, anterior, and dorsal views, $\times 1$, of a long, slender individual with four costae, hypotype USNM 551502; 22-24, dorsal, side, and anterior views, $\times 1$, of another slender specimen, having four costae sharper than the preceding, hypotype USNM 551494a; 25-27, side, anterior, and dorsal views, $\times 1$, of a large anteriorly expanded specimen with three large median costae and two short ones on each flank, hypotype USNM 551497a; 28-30, anterior, dorsal, and side views, $\times 1$, of a large individual with four median costae, hypotype USNM 551496a; 31, dorsal valve interior of a young specimen, $\times 2$, showing long outer hinge plates, hypotype USNM $551501 ; 32,33$ posterior of ventral valve, $\times 2$, showing teeth and deltidial plates, and dorsal interior of the same specimen, $\times 2$, showing loop, hypotype USNM 551500 . (Localities: 1-12, North Carolina 1; 13-33, North Carolina 2) 

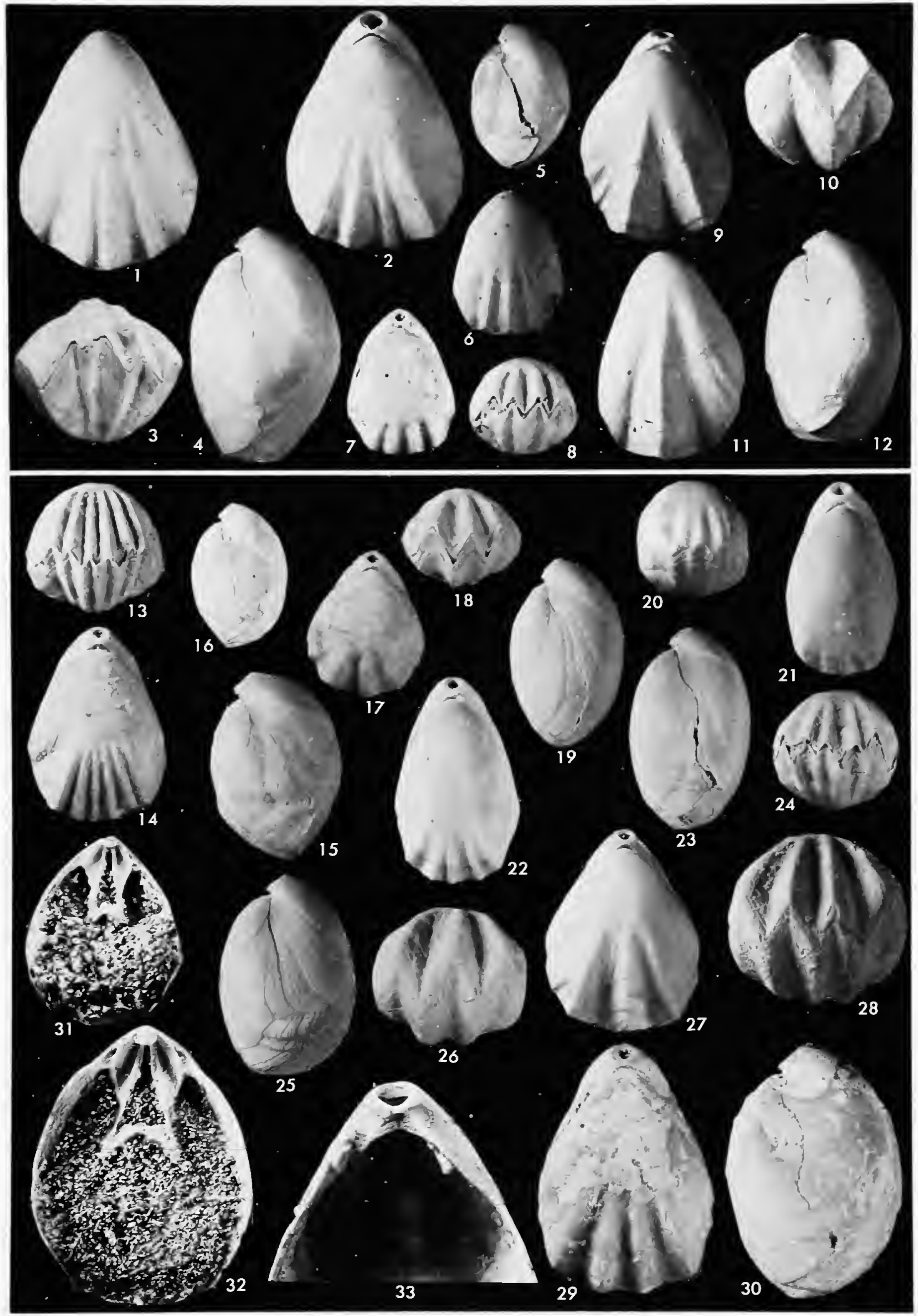
PLATE 9

FIGURES 1-40.-Plicatoria wilmingtonensis (Lyell and Sowerby): 1, Lyell and Sowerby's figure of the type specimen, $\times 1$ (Lyell and Sowerby, 1845:431, Oxford University Catalog number LT 58); 2-5, dorsal, anterior, ventral, and side views, $\times 1$, of a young specimen similar to Lyell and Sowerby's type, hypotype USNM $550879 ; 6-9$, ventral, anterior, side, and dorsal views, $\times 1$, of a small specimen developing costae, hypotype USNM 550877; 10, 11, original figures of Terebratula demissirostra Conrad (1875, pl. 3: figs. 1[7?], 1 (= Plicatoria wilmingtonensis (Lyell and Sowerby)); 12-14, anterior, dorsal, and side views, $\times 1$, of the smallest specimen exhibiting costation, hypotype USNM 550810a; 15 , large specimen in ventral view, $\times 1$, having the elongate form of $T$. demissirostra, hypotype USNM 550865a; 16-19, anterior, dorsal, ventral, and side views, $\times 1$, of a 'demissiform' specimen, hypotype USNM 550869; 20-23, anterior, dorsal, side, and ventral views, $\times 1$, of a specimen with seven short costae, hypotype USNM 550873; 24-27, ventral, side, anterior, and dorsal views, $\times 1$, of a young specimen with three anterior costae and an incipient fourth costa, hypotype USNM 551524; 28 , unusually large specimen, $\times 1$, with only incipent costae (type $C$ ), hypotype USNM $550812 ; 29-32$, anterior, side, dorsal, and ventral views, $\times 1$, of a specimen having three costae at midvalve and incipient anterior intercalations, hypotype USNM 548398n; 33, unusually large ventral valve with four costae starting at midvalve, $\times 1$, hypotype USNM 550876;34, dorsal view, $\times 1$, of a small narrow specimen with only three strong costae, hypotype USNM 550867; 35, an exceptionally wide specimen seen from the dorsal side, $\times 1$, having six short costae, hypotype USNM 550880; 36-39, anterior, side, ventral, and dorsal views, $\times 1$, of a small specimen with costae, hypotype USNM 550811; 40, large specimen with irregular incipient costation (type E), $\times 1$, hypotype USNM 550868. (Locality: North Carolina 1)

Figures 41-44.-Argyrotheca quadrata, new species: 41,42 , dorsal views of two specimens, $\times 10$, hypotypes USNM 551504a, b; 43, interior of the ventral valve, $\times 10$, showing septum with anterior pit, hypotype USNM 551504c; 44, interior of the dorsal valve, $\times 10$, hypotype USNM 551504d. (Locality: North Carolina 3)

Figures 45-50.-Argyrotheca laevis, new species: $45-48$, ventral, anterior, side, and dorsal views, $\times 10$, holotype USNM 551506a; 49 , interior of the dorsal valve, $\times 10$, paratype USNM 551506b; 50 , interior of the ventral valve, $\times 10$, showing median septum with anterior pit, paratype USNM 551506c. (Locality: South Carolina 5) 


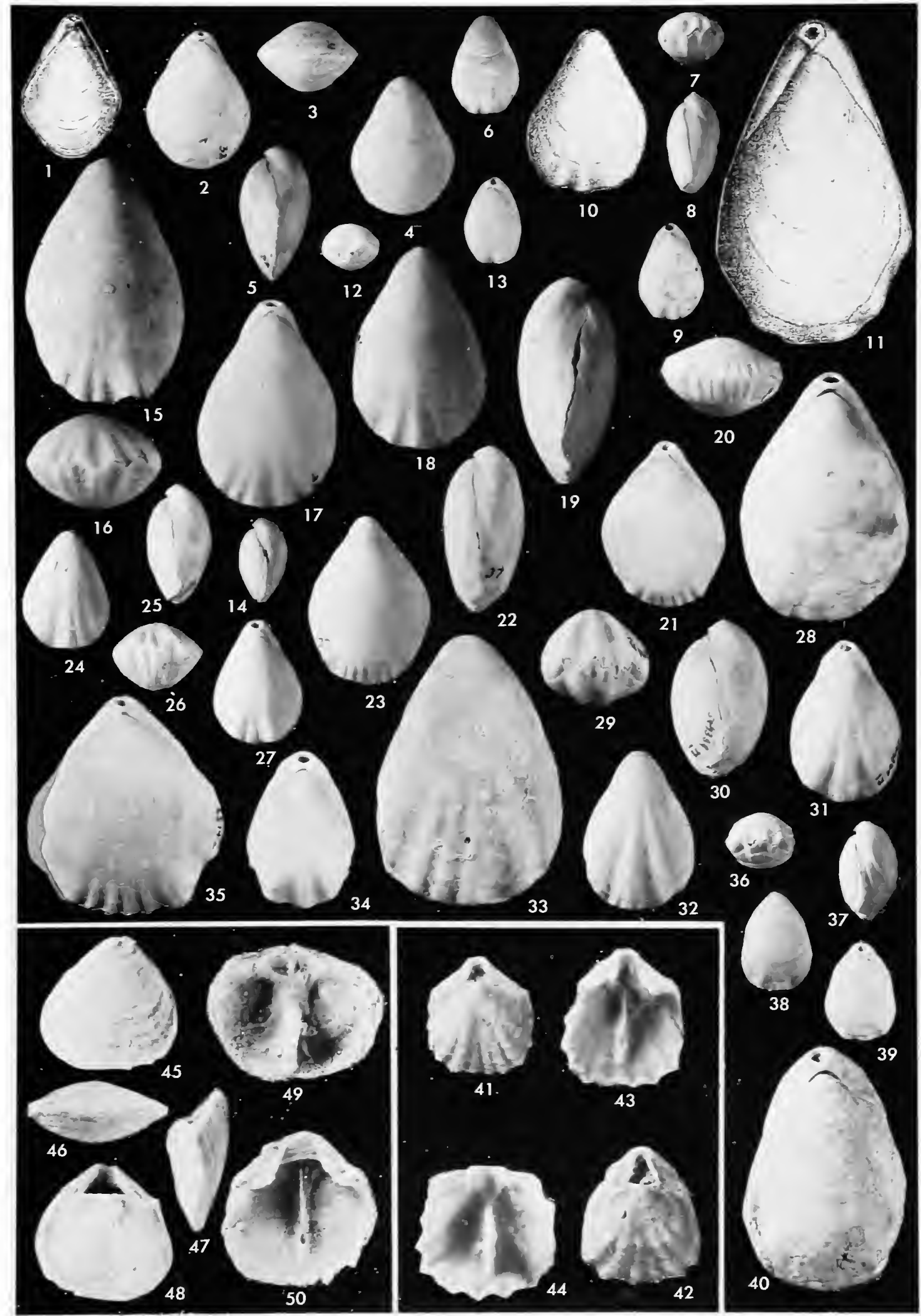

a U.S. GOVERNMENT PRINTING OFFICE: $1988-181-717 / 60009$ 





\section{REQUIREMENTS FOR SMITHSONIAN SERIES PUBLICATION}

Manuscripts intended for series publication receive substantive review (conducted by their originating Smithsonian museums or offices) and are submitted to the Smithsonian Institution Press with Form SI-36, which must show the approval of the appropriate authority designated by the sponsoring organizational unit. Requests for special treatment-use of color, foldouts, case-bound covers, etc.-require, on the same form, the added approval of the sponsoring authority.

Review of manuscripts and art by the Press for requirements of series format and style, completeness and clarity of copy, and arrangement of all material, as outlined below, will govern, within the judgment of the Press, acceptance or rejection of manuscripts and art.

Copy must be prepared on typewriter or word processor, double-spaced, on one side of standard white bond paper (not erasable), with 11/4" margins, submitted as ribbon copy (not carbon or xerox), in loose sheets (not stapled or bound), and accompanied by original art. Minimum acceptable length is 30 pages.

Front matter (preceding the text) should include: title page with only title and author and no other information, abstract page with author, title, series, etc., following the established format; table of contents with indents reflecting the hierarchy of heads in the paper; also, foreword and/or preface, if appropriate.

First page of text should carry the title and author at the top of the page; second page should have only the author's name and professional mailing address, to be used as an unnumbered footnote on the first page of printed text.

Center heads of whatever level should be typed with initial caps of major words, with extra space above and below the head, but no other preparation (such as all caps or underline, except for the underline necessary for generic and specific epithets). Run-in paragraph heads should use period/dashes or colons as necessary.

Tabulations within text (lists of data, often in parallel columns) can be typed on the text page where they occur, but they should not contain rules or numbered table captions.

Formal tables (numbered, with captions, boxheads, stubs, rules) should be submitted as carefully typed, double-spaced copy separate from the text; they will be typeset unless otherwise requested. If camera-copy use is anticipated, do not draw rules on manuscript copy.

Taxonomic keys in natural history papers should use the aligned-couplet form for zoology and may use the multi-level indent form for botany. If cross referencing is required between key and text, do not include page references within the key, but number the keyed-out taxa, using the same numbers with their corresponding heads in the text.

Synonymy in zoology must use the short form (taxon, author, year:page), with full reference at the end of the paper under "Literature Cited." For botany, the long form (taxon, author, abbreviated journal or book title, volume, page, year, with no reference in "Literature Cited") is optional.

Text-reference system (author, year:page used within the text, with full citation in "Literature Cited" at the end of the text) must be used in place of bibliographic footnotes in all Contributions Series and is strongly recommended in the Studies Series: "(Jones, 1910:122)" or ". . Jones (1910:122)." If bibliographic footnotes are required, use the short form (author, brief title, page) with the full citation in the bibliography.

Footnotes, when few in number, whether annotative or bibliographic, should be typed on separate sheets and inserted immediately after the text pages on which the references occur. Extensive notes must be gathered together and placed at the end of the text in a notes section.

Bibliography, depending upon use, is termed "Literature Cited," "References," or "Bibliography." Spell out titles of books, articles, journals, and monographic series. For book and article titles use sentence-style capitalization according to the rules of the language employed (exception: capitalize all major words in English). For journal and series titles, capitalize the initial word and all subsequent words except articles, conjunctions, and prepositions. Transliterate languages that use a non-Roman alphabet according to the Library of Congress system. Underline (for italics) titles of journals and series and titles of books that are not part of a series. Use the parentheses/colon system for volume (number): pagination; "10(2):5-9." For alignment and arrangement of elements, follow the format of recent publications in the series for which the manuscript is intended. Guidelines for preparing bibliography may be secured from Series Section, SI Press.

Legends for illustrations must be submitted at the end of the manuscript, with as many legends typed, double-spaced, to a page as convenient.

Illustrations must be submitted as original art (not copies) accompanying, but separate from, the manuscript. Guidelines for preparing art may be secured from Series Section, SI Press. All types of illustrations (photographs, line drawings, maps, etc.) may be intermixed throughout the printed text. They should be termed Figures and should be numbered consecutively as they will appear in the monograph. If several illustrations are treated as components of a single composite figure, they should be designated by lowercase italic letters on the illustration; also, in the legend and in text references the italic letters (underlined in copy) should be used: "Figure 9b." Illustrations that are intended to follow the printed text may be termed Plates, and any components should be similarly lettered and referenced: "Plate 9 b." Keys to any symbols within an illustration should appear on the art rather than in the legend.

Some points of style: Do not use periods after such abbreviations as "mm, ft, USNM, NNE." Spell out numbers "one" through "nine" in expository text, but use digits in all other cases if possible. Use of the metric system of measurement is preferable; where use of the English system is unavoidable, supply metric equivalents in parentheses. Use the decimal system for precise measurements and relationships, common fractions for approximations. Use day/month/year sequence for dates: "9 April 1976." For months in tabular listings or data sections, use three-letter abbreviations with no periods: "Jan, Mar, Jun," etc. Omit space between initials of a personal name: "J.B. Jones."

Arrange and paginate sequentially every sheet of manuscript in the following order: (1) title page, (2) abstract, (3) contents, (4) foreword and/or preface, (5) text, (6) appendixes, (7) notes section, (8) glossary, (9) bibliography, (10) legends, (11) tables. Index copy may be submitted at page proof stage, but plans for an index should be indicated when manuscript is submitted. 

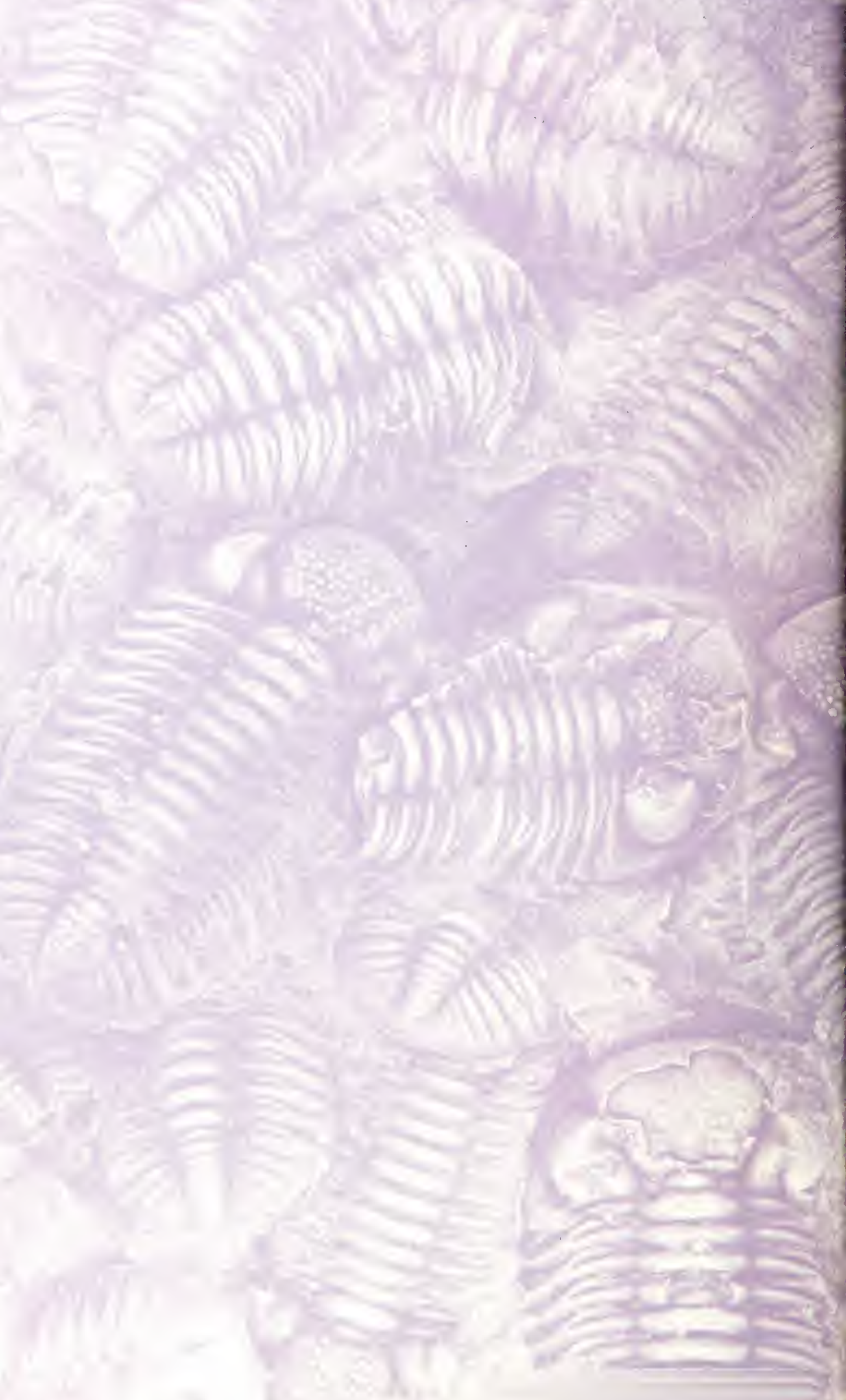